\title{
AHSON RISETRO
}

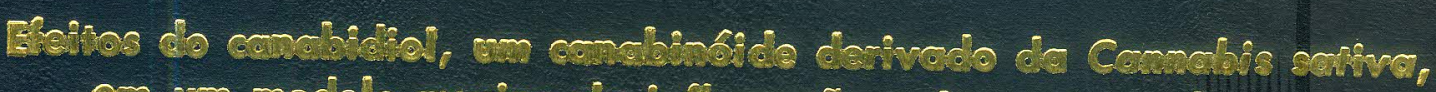

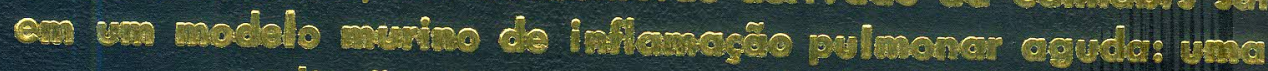

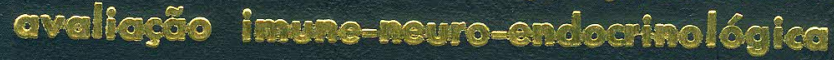

\section{Sฮ์ Paulo}

2012 


\section{ALISON RIBEIRO}

Efeitos do canabidiol, um canabinóide derivado da Cannabis sativa, em um modelo murino de inflamação pulmonar aguda: uma avaliação imuneneuro-endocrinológica 


\section{ALISON RIBEIRO}

\section{Efeitos do canabidiol, um canabinóide derivado da Cannabis sativa, em um modelo murino de inflamação pulmonar aguda: uma avaliação imune- neuro-endocrinológica}

Tese apresentada ao Programa de PósGraduação em Patologia Experimental e Comparada da Faculdade de Medicina Veterinária e Zootecnia da Universidade de São Paulo para obtenção do título de Doutor em Ciências

Departamento:

Patologia

Área de Concentração:

Patologia Experimental e Comparada

Orientador:

Prof. Dr. João Palermo Neto 
Autorizo a reprodução parcial ou total desta obra, para fins acadêmicos, desde que citada a fonte.

DADOS INTERNACIONAIS DE CATALOGAÇÃO-NA-PUBLICAÇÃO

(Biblioteca Virginie Buff D’Ápice da Faculdade de Medicina Veterinária e Zootecnia da Universidade de São Paulo)

Ribeiro, Alison

Efeitos do canabidiol, um canabinóide derivado da Cannabis sativa, em um modelo murino de inflamação pulmonar aguda: uma avaliação imuneneuro-endocrinológica / Alison Ribeiro. -- 2012.

$137 \mathrm{f}$.

Tese (Doutorado) - Universidade de São Paulo. Faculdade de Medicina Veterinária e Zootecnia. Departamento de Patologia, São Paulo, 2012.

Programa de Pós-Graduação: Patologia Experimental e Comparada.

Área de concentração: Patologia Experimental e Comparada.

Orientador: Prof. Dr. João Palermo Neto.

1. Canabidiol. 2. Injúria pulmonar aguda. 3. Inflamação. 4. Citocinas próinflamatórias. 5. Receptor de adenosina A2A. I. Título. 


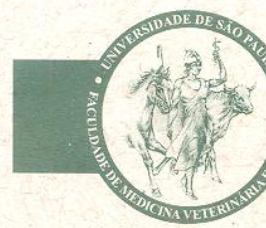

UNIVERSIDADE DE SÃO PAULO

FACULDADE DE MEDICINA VETERINÁRIA E ZOOTECNIA

Comissão de Ética no uso de animais

\section{CERTIFICADO}

Certificamos que o Projeto intitulado "Efeitos do canabidiol em um modelo murino de inflamação aguda pulmonar induzida por LPS", protocolado sob o ${ }^{\circ}$ 2002/2010, utilizando 220 (duzentos e vinte) camundongos, sob a responsabilidade do Prof. Dr. João Palermo Neto, está de acordo com os princípios éticos de experimentação animal da "Comissão de Ética no uso de animais" da Faculdade de Medicina Veterinária e Zootecnia da Universidade de São Paulo e foi aprovado em reunião de 29/09/2010.

We certify that the Research "Effects of cannabidiol in a murine model of acute lung inflammation induced by LPS", protocol number 2002/2010, utilizing 220 (two hundred and twenty) mice, under the responsibility Prof. Dr. João Palermo Neto, agree with Ethical Principles in Animal Research adopted by "Ethic Committee in the use of animals" of the School of Veterinary Medicine and Animal Science of University of São Paulo and was approved in the meeting of day $09 / 29 / 2010$.

São Paulo, 30 de setembro de 2010

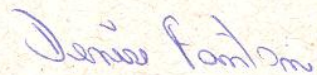

Profa. Dra. Denise Tabacchi Fantoni Presidente 


\section{FOLHA DE AVALIAÇÃO}

Nome: RIBEIRO, Alison

Título: Efeitos do canabidiol, um canabinóide derivado da Cannabis sativa, em um modelo murino de inflamação pulmonar aguda: uma avaliação imune-neuroendocrinológica

Tese apresentada ao Programa de Pós-Graduação em Patologia Experimental e Comparada da Faculdade de Medicina Veterinária e Zootecnia da Universidade de São Paulo para obtenção do título de Doutor em Ciências

Data:

Banca examinadora

Prof. Dr.:

Instituição:

Prof. Dr.:

Instituição:

Prof. Dr.:

Instituição:

Prof. Dr.:

Instituição:

Prof. Dr.:

Instituição: 
Dedico este trabalho ao grande mestre e mentor Prof. João Palermo Neto. Sem sua dedicação incondicional, não teria sido capaz de realizar este trabalho. Tive o prazer de ter sido seu aluno de mestrado e de continuar sob sua orientação em meu doutoramento. Nunca me perguntei se teria sido melhor mudar meu caminho, pois não tenho a menor dúvida que estive com um dos melhores. Com o senhor, aprendi muito mais do que ciência, aprendi lições de vida que ficarão para o resto de minha vida e, por tudo isso, tenha certeza, serei sempre grato. 
Dedico, também, este trabalho à minha amada esposa, Viviane. Sem ela eu não estaria completo hoje, pois somente quando me uní a ela percebi que minha vida estava vazia. Sem ela jamais teria conseguido percorrer os caminhos tortuosos e cheio de provações para chegar a este ponto. Só ela sabe o quão difícil foi percorrer este caminho, mas com sua ajuda chego ao final dessa jornada de cabeça erguida e com a consciência de que trilhei o bom caminho. Te amo! 
Por fim, dedico este trabalho à minha família, meu pai José Carlos, minha mãe Ivone, meu irmão Cleber e à memória de minha irmã Daiane, que partiu cedo demais. Renato Russo escreveu: “É tão estranho, os bons morrem jovens. Me lembro de você e de tanta gente que se foi cedo demais". Dedico este trabalho à estas pessoas que partipam e que participaram de minha vida, pois sem vocês eu não seria quem sou e só vocês realmente sabem a pessoa que sou. Amo vocês de todo meu coração! 


\section{AGRADECIMENTOS}

Um agradecimento especial às pessoas especiais, pois como dizem "a gratidão é a virtude das almas nobres".

Ao Prof. Dr. João Palermo Neto pela orientação no mestrado e no doutorado, pela paciência e pela doação do seu conhecimento. Muito obrigado!

À FAPESP pelo apoio financeiro concedido na forma de projetos temáticos (04/14128-0 e 09/51886-3) do qual este trabalho faz parte.

Ao CNPq pelo apoio financeiro na forma de bolsa (Cota Institucional, no processo $140325 / 2008-5)$.

Ao Departamento de Patologia (VPT) por permitir que eu fizesse meu mestrado e doutorado em suas dependências.

Aos Professores da FMRP-USP, Dr. José A. Crippa, Dr. Antônio W. Zuardi e Dr. Jaime E. Hallak, por fornecer o canabidiol e também pela colaboração no trabalho. Aos Professores do Departamento de Patologia (VPT) da FMVZ-USP, Dr. Frederico A. Costa Pinto (Fredão) e Dr. Luis Carlos de Sá Rocha (Lu). Vocês sempre foram grandes exemplos de conhecimento científico. Agradeço pelo aprendizado que tive com vocês ao longo desses anos e pela amizade.

Ao Dr. Daniel W. H: Cohn (Natô), obrigado pela amizade, pelas conversas e "polêmicas". Certamente você é um dos responsáveis pela criticidade que tenho hoje.

À Dra. Luciana Vismari (Lu), por sempre ter acreditado em mim e pela grande amizade que temos hoje. Agradeço também ao seu marido Fábio, por ter sido um grande incentivador. 
À minha esposa Viviane, por sempre ter estado ao meu lado, nos bons e nos maus momentos (e não foram poucos). Você transformou esta etapa da minha vida muito mais prazerosa e feliz. Te amo!

À minha família, meu pai José Carlos, minha mãe Ivone e meu irmão Cleber. Obrigado pelo carinho, compreensão e suporte. Amo vocês!

Aos funcionários do VPT por manterem a máquina funcionando. Um agradecimento especial aos funcionários do biotério (Cláudia, Idalina, Rosires, Nelsinho, Mauro e Luciana), do laboratório de farmacologia e toxicologia (Priscila, Ricardo, Herculano, Vagner e Nicole), do laboratório de histologia (Luciano Buga e Cláudio) e da secretaria do departamento (Adriana, Milena e Cris).

À Dra. Ana Paula Ligeiro de Oliveira (Aninha), primeiramente por ter auxiliado na escolha do modelo utilizado, mas também pela agradável convivência ao longo dos anos. Valeu Aninha!

Ao João Gimenes e à Luana pela ajuda no início do projeto com o modelo e também pela ajuda em alguns experimentos, mas sobretudo pela agradável convivência. Ao grande amigo Rodrigo Vieira, por estar lá sempre que precisamos e pela amizade construída ao longo dos anos.

À grande amiga e madrinha de casamento Milena Lobão Pinheiro, por estar sempre por perto, por ser uma grande ouvinte e por se preocupar genuinamente comigo.

Por fim, não poderia deixar de agradecer aos grandes amigos que fiz aqui e que deixo, mas que serão lembrados com muito carinho: Adriana Tiemi Akamine, André Vinicius Siqueira Gomes, Carolina Costola, Denise Kinoshita, Domênica Palomaris, Eduardo Zarzana, Emily Baskerville, Mônica Sakai, Renato Couto Moraes, Thiago Aloia, Vinícius Izídio de Almeida e Wanderley M. Quinteiro Filho. 
"O único homem que está isento de erros, é aquele que não arrisca acertar." Albert Einstein 


\section{RESUMO}

RIBEIRO, A. Efeitos do canabidiol, um canabinóide derivado da Cannabis sativa, em um modelo murino de inflamação pulmonar aguda: uma avaliação imune-neuro-endocrinológica. [Effects of cannabidiol, a Cannabis sativa-derived cannabinoid, in a murine model of acute lung injury: an immune-neuro-endocrine evaluation]. 2012. $137 \mathrm{f}$. Tese (Doutorado em Ciências) - Faculdade de Medicina Veterinária e Zootecnia, Universidade de São Paulo, São Paulo, 2012.

O canabidiol (CBD), o principal canabinóide não psicotrópico extraído da marijuana (Cannabis sativa), é reconhecido por sua potente propriedade imunosupressora e anti-inflamatória. A injúria pulmonar aguda (ALI) é uma doença inflamatória para qual ainda não foi desenvolvida terapias específicas e a única alternativa de tratamento é meramente de suporte em UTI. Desta forma, foi proposta uma investigação sobre os efeitos anti-inflamatórios do CBD em um modelo murino de $A L I$, induzida pela instilação intra-nasal de LPS (lipopolissacarídeo), dentro de uma perspectiva imuneneuro-endocrinológica. Para a análise do potencial anti-inflamatório do CBD, avaliouse a contagem total e diferencial de células do lavado broncoalveolar (LBA) (análise da migração de leucócitos para os pulmões), a atividade de mieloperoxidase (MPO) no tecido pulmonar (análise indireta da atividade de neutrófilos), a produção de citocinas e quimicionas no sobrenadante do LBA (análise do perfil inflamatório pulmonar), a concentração de proteínas (albumina) no sobrenadante do LBA (análise indireta da permeabilidade vascular pulmonar) e a expressão de moléculas de adesão (ICAM-1 e VLA-4) em leucócitos do LBA. Analisou-se, ainda, o mecanismo farmacológico dos efeitos anti-inflamatórios do CBD no modelo de ALI, utilizando-se de um antagonista altamente seletivo para o receptor de adenosina A2A (ZM241385). Por fim, avaliou-se os efeitos neuroendócrinos do CBD na vigência da inflamação pulmonar; analisou-se a atividade geral dos animais no campo aberto (análise do comportamento doentio) e os níveis séricos de corticosterona (análise da ativação do eixo Hipotálamo-Hipófise-Adrenal (HPA)). Mostrou-se que tanto o tratamento prolifático (antes da indução da inflamação) como o tratamento terapêutico (depois da indução da inflamação), com uma dose única de CBD (20 ou $80 \mathrm{mg} / \mathrm{kg}$ ) apresenta um efeito anti-inflamatório prolongado em camundongos submetidos ao modelo de ALI (principalmente 1 e 2 dias após a indução da inflamação). Mostrou-se que o CBD diminuiu a migração de leucócitos para os pulmões (neutrófilos, macrófagos e linfócitos), diminuiu a produção de citocinas (TNF e IL-6) e quimicinas (MCP-1 e MIP-2) no LBA, diminuiu a atividade 
MPO no tecido pulmonar, diminuiu a concentração de albumina no LBA e diminuiu a expressão de moléculas de adesão (ICAM-1) em neutrófilos do LBA. Mostrou-se, ainda, que o receptor de adenosina $A 2 A$ está envolvido nos efeitos anti-inflamatórios do CBD na ALI, uma vez que o tratamento com o ZM241385 aboliu todos os efeitos anti-inflamatórios descritos previamente. Por fim, mostrou-se que o CBD apresentou poucos efeitos comportamentais no campo aberto e que não ativou o eixo HPA. Desta forma, mostrou-se pela primeira vez que o tratamento profilático e, também, o tratamento terapêutico com CBD (20 ou $80 \mathrm{mg} / \mathrm{kg}$ ) tem um efeito anti-inflamatório prolongado em um modelo murino de $\mathrm{ALI}$, muito provavelmente em decorrência de um aumento da sinalização via receptor de adenosina A2A. Por esta razão, acreditase que o CBD possa ser considerado, no futuro, uma ferramenta terapêutica útil no tratamento de doenças inflamatórias pulmonares.

Palavras-chave: Canabidiol. Injúria pulmonar aguda. Inflamação. Citocinas próinflamatórias. Receptor de adenosina A2A. 


\section{ABSTRACT}

RIBEIRO, A. Effects of cannabidiol, a Cannabis sativa-derived cannabinoid, in a murine model of acute lung injury: an immune-neuro-endocrine evaluation. [Efeitos do canabidiol, um canabinóide derivado da Cannabis sativa, em um modelo murino de inflamação pulmonar aguda: uma avaliação imune-neuroendocrinológica]. 2012. 137 f. Tese (Doutorado em Ciências) - Faculdade de Medicina Veterinária e Zootecnia, Universidade de São Paulo, São Paulo, 2012.

Cannabidiol (CBD), the major non-psychotropic plant (Cannabis sativa)-derived cannabinoid, is recognized for its immunossupressant and anti-inflammatory properties. Acute lung injury $(A L I)$ is an inflammatory condition for which treatment is mainly supportive (ICU patients), because effective therapies have not been developed. Therefore, it was proposed an investigation in order to address the antiinflammatory effects of CBD in a murine model of LPS-induced ALI, within an immune-neuro-endocrine perspective. To analyze the potential anti-inflammatory effect of CBD, it was evaluated total and differencial cell count of leukocytes present in the bronchoalveolar lavage (BAL) (migration of leukocytes into the lungs), myeloperoxidase activity in the lung tissue (indirect analysis of neutrophil activity), production of cytokines and chemokines in the BAL (analysis of the pulmonar inflammatory profile), protein (albumin) concentration in the BAL (indirect analysis of pulmonar vascular permeability), and expression of adhesion molecules (ICAM-1 and VLA-4) in leukocytes of the BAL. It was also analyzed the pharmacologic mechanism of the anti-inflammatory effects of $C B D$ in the model of $A L I$, by using a highly selective antagonist of the adenosine A2A receptor (ZM241385). Finally, it was analyzed the neuro-endocrine effects of CBD in the context of lung inflammation; it was analyzed the general activity of the mice in the open field (analysis of sickness behavior) and the seric levels of corticosterone (activation of HPA (HypothalamusHypophysis-Adrenal) axis). It was shown that both prophylactic (before the induction of inflammation) and therapeutic (after the induction of inflammation) protocols of treatment, with a sigle dose of CBD (20 or $80 \mathrm{mg} / \mathrm{kg}$ ), has a long-term antiinflammatory effect in mice submitted to the model of ALI (specially, after 1 and 2 days of the induction of inflammation). It was shown that CBD decreased leukocyte (neutrophil, macrophage, and lymphocytes) migration into the lungs, decreased cytokines (TNF and IL-6) and chemokines (MCP-1 and MIP-2) in the BAL, decreased MPO activity in the lung tissue, decreased albumin concentration in the BAL, and decreased adhesion molecule expression (ICAM-1) in neutrophils of the BAL. It was 
also shown that adenosine A2A receptor is involved in the anti-inflammatory effects of CBD on LPS-induced ALI, because ZM241385 abrogated all of the antiinflammatory effects of cannabidiol previously described. Finally, it was shown that CBD has discreet behavioral effects in the open field and was not able to activate the HPA axis. Thus, it was shown for the first time that both prophylactic and also therapeutic treatment with CBD (20 or $80 \mathrm{mg} / \mathrm{kg}$ ) has a long-term anti-inflammatory effect in a murine model of ALI, most likely associated with an increase in the signaling through the adenosine A2A receptor. Hence, it is possible that in the future CBD may prove useful as a therapeutical tool in the treatment of pulmonar inflammatory conditions.

Key-words: Cannabidiol. Acute lung injury. Inflammation. Pro-inflammatory cytokines. Adenosine A2A receptor. 


\section{LISTA DE FIGURAS}

Figura 1 - Representação esquemática do procedimento de coleta de lavado broncoalveolar (LBA).

Figura 2 - (A) Citograma que ilustra as populações de nanobeads da curva padrão para as diferentes citocinas na concentração de $625 \mathrm{pg} / \mathrm{mL}$. (B) Histograma que ilustra os picos de intensidade de fluorescência para os diferentes populações de nanobeads. Figura adaptada do manual do usuário do CBA mouse inflammation kit - BD Biosciences.......................49

Figura 3 - Dot plots representativos utilizados na análise do percentual de células $T$ regulatórias (CD4+FoxP3+). (A) Dot plot de células T marcadas em sua superfície com anticorpo anti-CD4 conjugado com PE. (B) Dot plot de células $T$ regulatórias duplo-positivas para proteína verde fluorescente (FoxP3+) e marcadas em sua superfície com anticorpo anti-CD4 conjugado com PE ....

Figura 4 - Imagem do campo aberto utilizado na aquisição dos dados comportamentais.

Figura 5 - Curva dose-resposta construída para avaliação dos efeitos do tratamento com CBD em um modelo murino de injúria pulmonar aguda (ALI). (A) contagem de leucócitos totais no LBA e (B) concentração de TNF no LBA. ${ }^{*} p<0,05,{ }^{* *} p<0,001 e^{* * *} p<0,0001$ quando comparados ao grupo veículo+LPS. ANOVA de uma via seguido do teste de TukeyKramer de comparações múltiplas, $n=4-5$ animais/grupo .

Figura 6 - Representação esquemática do protocolo experimental profilático de tratamento e indução da inflamação pulmonar

Figura 7 - Efeitos do CBD sobre a migração de leucócitos para os pulmões de camundongos submetidos ao modelo murino de ALI, 1, 2, 4 e 7 dias após a indução da inflamação. ${ }^{* *} p<0,001 e^{* * *} p<0,0001$ quando comparados ao grupo veículo+LPS. ANOVA de uma via seguido do teste de Tukey-Kramer de comparações múltiplas, $n=4-9$ animais/grupo

Figura 8 - Efeitos do CBD sobre a atividade de MPO no tecido pulmonar de camundongos submetidos ao modelo de ALI. * $p<0,05 e^{* *} p<0,001$ quando comparados ao grupo veículo+LPS. Teste de Mann-Whitney $U$ para comparação de dados não-paramétricos entre 2 grupos, $n=4-8$ animais/grupo

Figura 9 - Efeitos do CBD sobre a produção de citocinas e quimiocinas em camundongos submetidos ao modelo de ALI. (A) TNF, (B) IL-6, (C) MCP-1 e (D) MIP-2. * $p<0,05,{ }^{* *} p<0,001 e^{* * *} p<0,0001$ quando comparados ao grupo veículo+LPS. ANOVA de uma via seguido do teste de Tukey-Kramer de comparações múltiplas e teste de KruskalWallis seguido do teste de Dunn de comparações múltiplas, $n=4-7$ animais/grupo

Figura 10 - Efeitos do CBD sobre a concentração de albumina no LBA de camundongos submetidos ao modelo de ALI. * $\mathrm{p}<0,05$ quando comparados ao grupo veículo+LPS. Teste de Mann-Whitney $U$ para 
comparação de dados não-paramétricos entre 2 grupos, $n=4-7$ animais/grupo ............................................................................... 72

Figura 11 - Representação esquemática do protocolo experimental de tratamento e indução da inflamação pulmonar.

Figura 12 - Efeitos do antagonismo do receptor de adenosina A2A nos efeitos do CBD sobre a migração de células para os pulmões de camundongos submetidos ao modelo de ALI. * $p<0,05 e^{* * *} p<0,0001$ quando comparados ao grupo ZM+veículo+LPS e ZM+CBD 20+LPS. ANOVA de uma via seguido do teste de Tukey-Kramer de comparações múltiplas, $n$ = 4-7 animais/grupo. 76

Figura 13 - Efeitos do antagonismo do receptor de adenosina A2A nos efeitos do CBD sobre a migração de células para os pulmões de camundongos submetidos ao modelo de ALI. * $p<0,05$ quando comparados ao grupo ZM+veículo+LPS e ZM+CBD 20+LPS. Kruskal-Wallis seguido do teste de Dunn de comparações múltiplas, $n=5-9$ animais/grupo .77

Figura 14 - Efeitos do antagonismo do receptor de adenosina A2A nos efeitos do CBD sobre a concentração de citocinas e quimiocinas no LBA de camundongos submetidos ao modelo de ALI. (A) TNF, (B) IL-6, (C) MCP-1 e (D) MIP-2. * $p<0,05$ e ** $p<0,001$ quando comparados ao grupo ZM+veículo+LPS e ZM+CBD 20+LPS. ANOVA de uma via seguido do teste de Tukey-Kramer de comparações múltiplas e KruskalWallis seguido do teste de Dunn de comparações múltiplas, $n=4-8$ animais/grupo

Figura 15 - Efeitos do antagonismo do receptor de adenosina A2A nos efeitos do CBD sobre a migração de células para os pulmões de camundongos submetidos ao modelo de ALI. * $p<0,05 e^{* *} p<0,001$ quando comparados ao grupo ZM+veículo+LPS e ZM+CBD 20+LPS. KruskalWallis seguido do teste de Dunn de comparações múltiplas, $n=4-8$ animais/grupo

Figura 16 - Efeitos do CBD sobre o percentual de células Treg no LBA, no sangue e no baço de camundongos submetidos ao modelo de ALI, 1 dia após a indução da inflamação. ${ }^{* *} p<0,001 e^{* * *} p<0,0001$ quando comparados aos grupos veículo+sal e veículo+LPS. ANOVA de uma via seguido do teste de Tukey-Kramer de comparações múltiplas, $n=5-10$ animais/grupo .86

Figura 17 - Efeitos do CBD sobre o percentual de células Treg no LBA, no sangue e no baço de camundongos submetidos ao modelo de ALI, 2 dias após a indução da inflamação. ** $p<0,001$ quando comparados aos grupos veículo+sal e veículo+LPS. ANOVA de uma via seguido do teste de Tukey-Kramer de comparações múltiplas, $n=4-7$ animais/grupo

Figura 18 - Representação esquemática do protocolo experimental terapêutico de tratamento e indução da inflamação pulmonar

Figura 19 - Efeitos do tratamento terapêutico com CBD sobre a migração de leucócitos para os pulmões de camundongos submetidos ao modelo murino de ALI, 1 e 2 dias após a indução da inflamação. ${ }^{* *} p<0,001$ e ${ }^{* * *} p<0,0001$ quando comparados ao grupo LPS+veículo. ANOVA de 
uma via seguido do teste de Tukey-Kramer de comparações múltiplas, $\mathrm{n}$

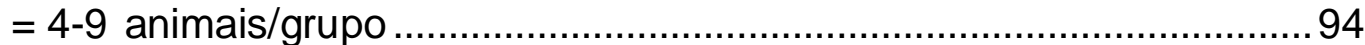

Figura 20 - Efeitos do tratamento terapêutico com CBD sobre a atividade de MPO no tecido pulmonar de camundongos submetidos ao modelo murino de ALI, 1 e 2 dias após a indução da inflamação. ${ }^{* *} p<0,001$ quando comparados ao grupo LPS+veículo. Kruskal-Wallis seguido do teste de Dunn de comparações múltiplas, $n=4-9$ animais/grupo 100

Figura 21 - Efeitos do tratamento terapêutico com CBD sobre a produção de citocinas e quimiocinas em camundongos submetidos ao modelo de ALI. (A) TNF, (B) IL-6, (C) MCP-1 e (D) MIP-2. * $p<0,05,{ }^{* *} p<0,001 e^{* * *} p$ $<0,0001$ quando comparados ao grupo veículo+LPS. ANOVA de uma via seguido do teste de Tukey-Kramer de comparações múltiplas, $n=5-8$ animais/grupo 104

Figura 22 - Efeitos do tratamento terapêutico com CBD sobre a concentração de proteína no LBA de camundongos submetidos ao modelo murino de ALI, 1 e 2 dias após a indução da inflamação. * $p<0,05$ quando comparados ao grupo LPS+veículo. Kruskal-Wallis seguido do teste de Dunn de comparações múltiplas, $\mathrm{n}=4-9$ animais/grupo 106

Figura 23 - Efeitos do tratamento terapêutico com CBD sobre a expressão de moléculas de adesão em neutrófilos do LBA de camundongos submetidos ao modelo murino de ALI, 1 dia após a indução da inflamação. * $p<0,05$ quando comparados ao grupo LPS+veículo. Kruskal-Wallis seguido do teste de Dunn de comparações múltiplas, $\mathrm{n}=$ 4-10 animais/grupo 108 


\section{LISTA DE TABELAS}

Tabela 1 - Curva dose-resposta construída para avaliação dos efeitos do tratamento com CBD em um modelo murino de injúria pulmonar aguda (ALI) .........57

Tabela 2 - Efeitos do CBD sobre a migração de leucócitos para os pulmões de camundongos submetidos ao modelo de ALI

Tabela 3 - Efeitos do CBD sobre a contagem diferencial de leucócitos no LBA de camundongos submetidos ao modelo de ALI

Tabela 4 - Efeito do CBD sobre a distribuição de leucócitos na medula óssea e no sangue de camundongos submetidos ao modelo de ALI.

Tabela 5 - Efeito do CBD sobre a atividade de MPO no tecido pulmonar de camundongos submetidos ao modelo de ALI

Tabela 6 - Efeitos do CBD sobre a produção de citocina e quimiocinas no LBA de camundongos submetidos ao modelo de ALI

Tabela 7 - Efeitos do CBD sobre a concentração de albumina no LBA de camundongos submetidos ao modelo de ALI.

Tabela 8 - Efeito do antagonismo do receptor de adenosina A2A nos efeitos do CBD sobre a migração de leucócitos para os pulmões de camundongos submetidos ao modelo de ALI .

Tabela 9 - Efeito do antagonismo do receptor de adenosina A2A nos efeitos do CBD sobre a atividade de MPO no tecido pulmonar de camundongos submetidos ao modelo de ALI

Tabela 10 - Efeito do antagonismo do receptor de adenosina A2A nos efeitos do CBD sobre a concentração de citocinas e quimiocinas no LBA de camundongos submetidos ao modelo de ALI

Tabela 11 - Efeito do antagonismo do receptor de adenosina A2A nos efeitos do CBD sobre a atividade de MPO no tecido pulmonar de camundongos submetidos ao modelo de ALI

Tabela 12 - Efeitos do CBD sobre o percentual de células Treg no LBA, no sangue e no baço de camundongos submetidos ao modelo de ALI.

Tabela 13 - Efeitos do CBD sobre parâmetros comportamentais no campo aberto de camundongos submetidos ao modelo de ALI, $6 \mathrm{~h}$ após a indução da inflamação.

Tabela 14 - Efeitos do CBD sobre parâmetros comportamentais no campo aberto de camundongos submetidos ao modelo de ALI, 24 h após a indução da inflamação.

Tabela 15 - Efeitos do CBD sobre a ativação do eixo HPA de camundongos submetidos ao modelo de ALI, 6 e 24 h após a indução da inflamação 91

Tabela 16 - Efeitos do tratamento terapêutico com o CBD sobre a migração de leucócitos para os pulmões de camundongos submetidos ao modelo de ALI 
Tabela 17 - Efeitos do tratamento terapêutico com CBD sobre a contagem de diferencial de leucócitos no LBA de camundongos submetidos ao modelo de ALI

Tabela 18 - Efeitos do tratamento terapêutico com CBD sobre a distribuição de leucócitos na medula óssea e no sangue de camundongos submetidos ao modelo de ALI .

Tabela 19 - Efeito do tratamento terapêutico com o CBD sobre a atividade de MPO no tecido pulmonar de camundongos submetidos ao modelo de ALI ..100

Tabela 20 - Efeitos do tratamento terapêutico com CBD sobre a produção de citocina e quimiocinas no LBA de camundongos submetidos ao modelo de ALI

Tabela 21 - Efeito do tratamento terapêutico com o CBD sobre a concentração de proteína no LBA de camundongos submetidos ao modelo de ALI .......106

Tabela 22 - Efeito do tratamento terapêutico com o CBD sobre a expressão de moléculas de adesão em neutrófilos do LBA de camundongos submetidos ao modelo de ALI ..... 


\section{LISTA DE ABREVIATURAS}

2-AG $=$ 2-araquidonilglicerol

$\mathrm{ACTH}=$ hormônio adenocorticotrópico

$\mathrm{AEA}=$ araquidoniletanolamida ou anandamida

$A L I=$ inflamação pulmonar aguda ou injúria pulmonar aguda

ARDS = síndrome do desconforto respiratório agudo

$\mathrm{CBD}=$ canabidiol

COX $=$ cicloxigenase

HPA = eixo hipotálamo-hipófise-adrenal, classicamente conhecido como HPA.

LBA = lavado broncoalveolar

LPS = lipopolissacarídeo

$\mathrm{MPO}=$ mieloperoxidase

OVA $=$ ovalbumina

PBS = tampão $\mathrm{pH} 7,4$

$\mathrm{SNC}=$ sistema nervoso central

$\mathrm{THC}=\Delta$ 9-tetrahidrocanabinol

Treg $=$ células $T$ regulatórias

$\mathrm{UTI}=$ unidade de terapia intensiva 


\section{SUMÁRIO}

1 INTRODUÇÃO

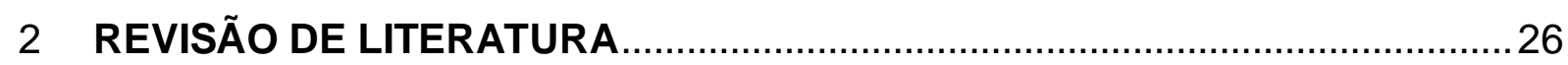

2.1 A neuroimunomodulação e o sistema endocanabinóide ...................................26

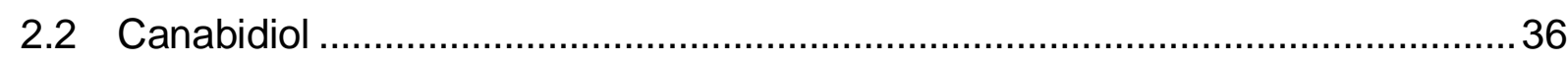

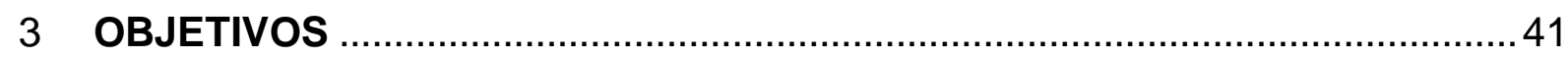

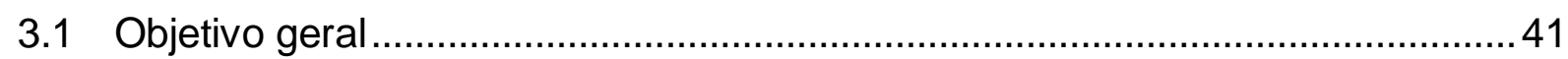

3.2 Objetivos específicos .............................................................................. 41

3.2.1 Em animais submetidos a um modelo de ALI, induzida pela administração intra-nasal de LPS, avaliar os efeitos do tratamento com CBD previamente à indução da inflamação sobre:

3.2.2 Em animais submetidos a um modelo de ALI, induzida pela administração intra-nasal de LPS, avaliar o mecanismo responsável pelos efeitos anti-inflamatórios do CBD administrado previamente à indução da inflamação sobre:

3.2.3 Em animais submetidos a um modelo de ALI, induzida pela administração intra-nasal de LPS, avaliar os efeitos do tratamento com CBD posteriomente à

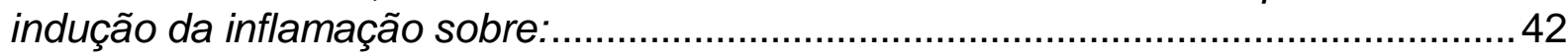

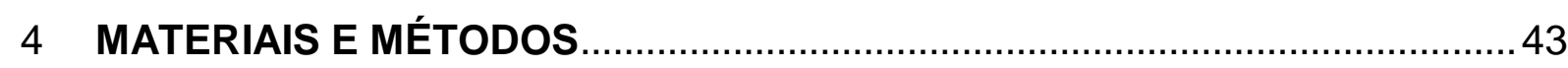

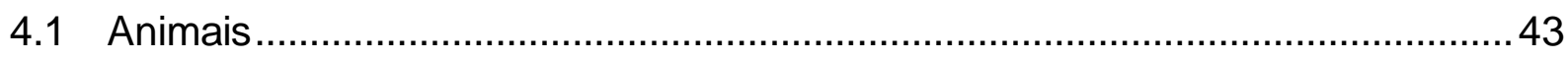

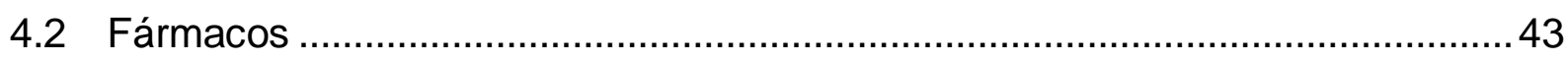

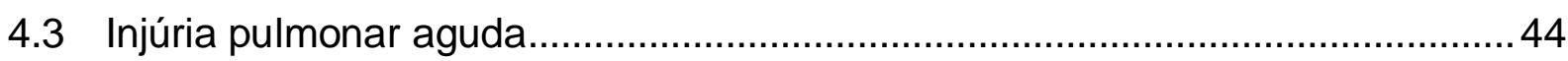

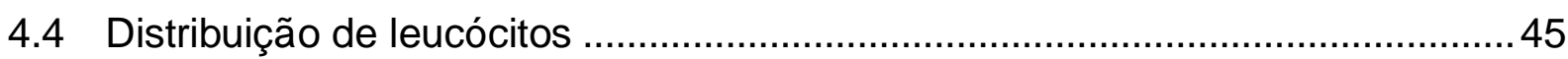

4.4.1 Lavado broncoalveolar (LBA) ............................................................... 45

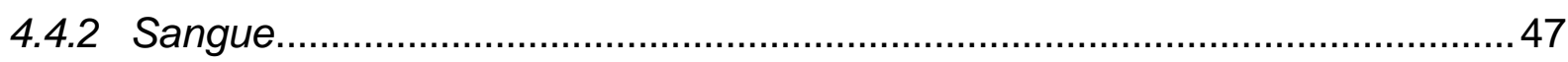

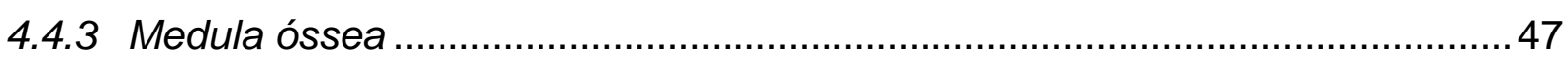

4.5 Atividade da mieloperoxidase (MPO) ...................................................... 47

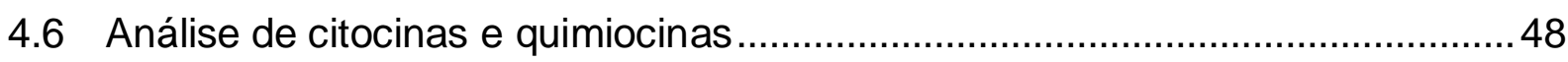

4.7 Análise de proteína (albumina) no LBA ......................................................50

4.8 Análise de células T regulatórias (CD4+FoxP3+) ….......................................50

4.9 Expressão de moléculas de adesão em leucócitos do LBA ..............................52

4.10 Medida da atividade geral no campo aberto ................................................52

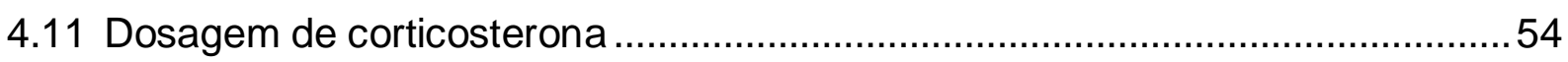

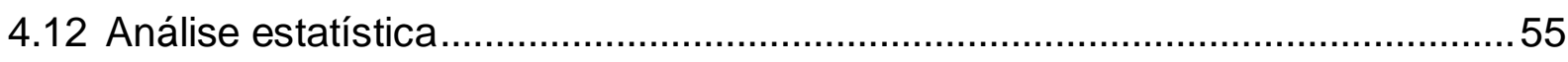

5 DELINEAMENTO EXPERIMENTAL E RESULTADOS .....................................56

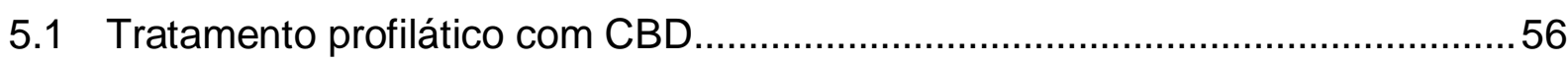

5.1.1 O CBD tem um efeito anti-inflamatório dose-dependente em um modelo murino de $A L I$. 
5.1.2 O tratamento com CBD diminui prolongadamente a migração de leucócitos para os pulmões

5.1.3 O tratamento com CBD não altera a distribuição de leucócitos na medula óssea e no sangue.

5.1.4 O CBD diminui a atividade de mieloperoxidase (MPO) no tecido pulmonar ...65

5.1.5 O CBD diminui a produção de citocinas e quimiocinas pró-inflamatórias no $\angle B A$.

5.1.6 O CBD diminui a permeabilidade do endotélio vascular pulmonar .71

5.1.7 $O$ antagonismo do receptor de adenosina A2A atenua os efeitos antiinflamatórios do CBD no modelo de ALI.

5.1.8 O CBD altera a percentagem de células $T$ regulatórias (CD4+FoxP3+) no

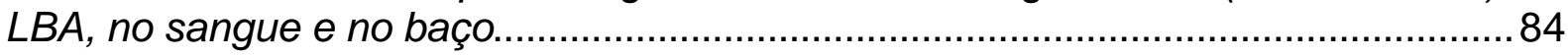

5.1.9 O CBD altera poucos parâmetros comportamentais no campo aberto ............87

5.1.10 CBD não altera os níveis de corticosterona no soro.....................................90

5.2 Tratamento terapêutico com CBD ............................................................92

5.2.1 O tratamento terapêutico com CBD diminui a migração de leucócitos para os pulmões.

5.2.2 O tratamento terapêutico com CBD não altera a distribuição de leucócitos na medula óssea e no sangue.

5.2.3 O tratamento terapêutico com CBD diminui a atividade de mieloperoxidase (MPO) no tecido pulmonar....

5.2.4 O tratamento terapêutico com CBD diminui a produção de citocinas $e$ quimiocinas pró-inflamatórias no LBA.

5.2.5 O tratamento terapêutico com CBD diminui a permeabilidade do endotélio vascular pulmonar 105

5.2.6 O tratamento terapêutico com CBD diminui a expressão de moléculas de adesão em neutrófilos do LBA.......................................................................... 107

6 DISCUSSÃO

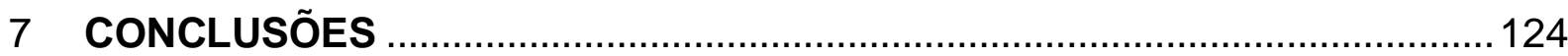

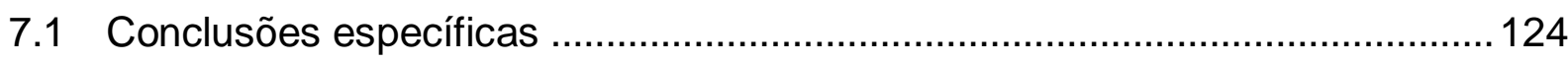

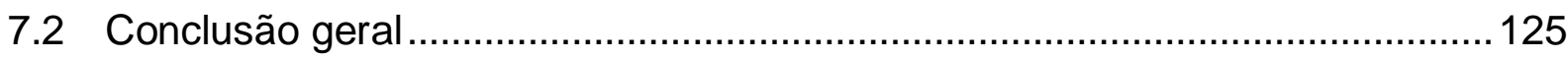

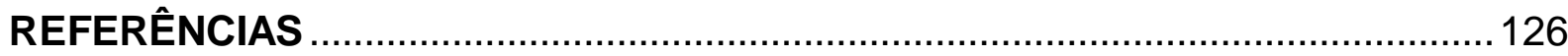




\section{INTRODUÇÃO}

Há muito se conhece a existência da interação entre o corpo e a mente. Aristóteles afirmava que a "psique" (alma) e o corpo reagiam complementariamente um ao outro; para ele, uma mudança no estado da psique produzia uma mudança na estrutuda do corpo e, inversamente, uma mudança na estrutura do corpo produzia uma mudança na estrutura da psique. Evidências convergentes dos campos da psicologia, neurobiologia e imunologia têm demonstrado que o sistema imune não é regulado de maneira exclusivamente autônoma, mas que é influenciado por fatores internos ou externos a ele direcionados pelo sistema nervoso central (SNC). Em contrapartida, o sistema imune, através da secreção de produtos como, por exemplo, de interleucinas, prostaglandinas e imunoglobulinas, modula a atividade do SNC. Atualmente, este ramo da ciência é denominado de neuroimunomodulação ou psiconeuroimunologia.

Uma das descobertas mais notáveis da biologia foi o compartilhamento bioquímico entre o SNC e o sistema imune, finalmente caracterizando as bases moleculares para as interações imune-neuro-endócrinas. De fato, sabe-se hoje que produtos do sistema imune e do eixo neuro-endócrino coexistem em tecidos linfóide, endócrino e neural. Hormônios, neurotransmissores e neuropeptídeos afetam o sistema imune, assim como produtos de células imunes e originados de processos inflamatórios, como interleucinas e prostaglandinas, afetam mecanismos neuroendócrinos. Desta forma, o sistema endocanabinóide se encaixa perfeitamente no contexto das bases moleculares para as interações imune-neuro-endócrinas, uma vez que seus receptores e ligantes coexistem tanto no SNC como no sistema imune.

Dentre os canabinóides extraídos da Cannabis sativa, o canabidiol é o que apresenta maior potencial terapêutico, seja por seus efeitos descritos no SNC seja pelos efeitos que produz na periferia, especialmente em processos inflamatórios. Desde a descoberta do sistema endocanabinóide no início da década de 90, a busca pelos efeitos dos canabinóides, principalmente do CBD, sobre a imunidade têm recebido grandes contribuições. No entanto, o potencial terapêutico anti-inflamatório do CBD em modelos de doença inflamatória ainda carece de um maior aprofundamento. 
A injúria pulmonar aguda (ALI) e, sua forma mais severa, a síndrome do desconforto respiratório agudo (ARDS), são doenças pulmonares de início agudo, caracterizadas por infiltrado pulmonar bilateral. A causa mais comum de ALI e ARDS em humanos é a sepsis, embora a seqüência exata de como isso ocorra não esteja muito bem elucidada. Infelizmente, os tratamentos disponíveis para ALI e ARDS são apenas de suporte e terapias específicas ainda não foram desenvolvidas.

Desta forma, decidimos estudar os efeitos do CBD em um modelo murino de ALI, induzida pela administração intranasal de LPS, que é caracterizado pelo acúmulo de neutrófilos, edema, destruição da integridade epitelial e extravasamento de proteínas para o espaço alveolar. Avaliamos, ainda, o mecanismo de ação envolvido nos efeitos anti-inflamatórios do CBD em nosso modelo. Adicionalmente, sabendo que a ativação do SI na periferia leva à ativação de diversas áreas no sistema nervoso central e que esta ativação leva à mudanças comportamentais e neuroendócrinas, decidimos avaliar os efeitos do CBD dentro de uma perspectiva neuroimunológica, buscando integrar o conhecimento das interações imune-neuroendócrina juntamente com os efeitos anti-inflamatórios do CBD. 


\section{REVISÃo DE LITERATURA}

\subsection{A neuroimunomodulação e o sistema endocanabinóide}

Há muito se conhece a existência da interação entre o corpo e a mente. Aristóteles afirmava que a "psique" (alma) e o corpo reagiam complementariamente um ao outro; para ele, uma mudança no estado da psique poduzia uma mudança na estrutuda do corpo e, inversamente, uma mudança na estrutura do corpo produzia uma mudança na estrutura da psique. Evidências convergentes dos campos da psicologia, neurobiologia e imunologia têm demonstrado que o sistema imune não é regulado de maneira exclusivamente autônoma, mas que é influenciado por fatores internos ou externos a ele direcionados pelo sistema nervoso central (SNC) (MADDEN; FELTEN, 1995; QUAN; BANKS, 2007). Em contrapartida, o sistema imune, através da secreção de produtos como, por exemplo, de interleucinas, prostaglandinas e imunoglobulinas, modula a atividade do SNC (BESEDOVSKY; DEL REY, 1996; GOEHLER; LYTE; GAYKEMA, 2007). Embora de conhecimento amplo, foi somente nas últimas décadas que se começou a dar maior importância ao estudo das interações neuroimunes, já que até então prevalecia uma tendência de setorização das abordagens experimentais que se faziam, quer no SNC quer no sistema imune (BESEDOVSKY; REY, 2007; COSTA-PINTO; PALERMO-NETO, 2010). Atualmente, este ramo da ciência é denominado de neuroimunomodulação ou psiconeuroimunologia; alguns ainda preferem a denominação interações imuneneuro-endócrinas ou imuno-neuro-endocrinológicos. Inicialmente, a neuroimunomodulação foi conceituada como a área de estudo que avaliava as influências exercidas pelo sistema nervoso sobre a resposta imune (REICHLIN, 1993). No entanto, graças à evolução dos conhecimentos nesta área da ciência atualmente ela é definida como a área que estuda as inter-relações existentes entre o SNC e o sistema imune (ALVES; PALERMO-NETO, 2007; COSTA-PINTO et al., 2009).

Destaque-se, a esse respeito, que as primeiras constatações da existência de comunicação entre os dois super-sistemas foram feitas de forma pioneira por Hans 
Selye (SELYE, 1998). Ele mostrou que o estresse causava alterações no tamanho do timo, do baço e dos linfonodos, o que atualmente podemos chamar de alterações de "cima para baixo" (modulação SNC $\Rightarrow$ sistema imune). Mais adiante, Wexler, Dolgin e Tryczynski (WEXLER; DOLGIN; TRYCZYNSKI, 1957) mostraram a ocorrência de uma ativação do eixo hipotálamo-hipófise-adrenal (HPA) após a administração de uma endotoxina bacteriana, o que podemos chamar de alterações de "baixo para cima" (modulação sistema imune $\Rightarrow$ SNC).

A neuroimunomodulação começou a tomar forma quando Besedovsky e Sorkin (1977) sugeriram que a imunoregulação não seria totalmente autônoma e que haveria uma interação imuno-neuroendócrina; que seria bidirecional (BESEDOVSKY; SORKIN, 1977). De fato, esses autores mostraram um aumento superior a $100 \%$ dos disparos de neurônios da porção ventromedial do hipotálamo após uma estimulação antigênica em ratos (BESEDOVSKY et al., 1977). Além disso, Besedovsky et al. (1986) confirmaram a hipótese relativa à interação bidirecional entre os sistemas neuroendócrino e imune, uma vez que mostraram ser a produção de algumas citocinas por células imunes, tais como Interleucina (IL)-1, inibida pelos glicocorticóides in vivo e in vitro (BESEDOVSKY et al., 1986). Também mostraram que os níveis séricos de glicocorticóides aumentavam por influência de fatores liberados por leucócitos humanos (citocinas) e que esta atividade era neutralizada pelo uso de um anticorpo anti-IL-1 (BESEDOVSKY et al., 1986).

O SNC regula o sistema imune através de dois mecanismos principais: (a) uma resposta hormonal ao estresse com a conseqüente produção de glicocorticóides e (b) uma resposta do Sistema Nervoso Autônomo, com a liberação de noradrenalina pelo Sistema Nervoso Simpático e de adrenalina pela medula da glândula adrenal (WEBSTER; TONELLI; STERNBERG, 2002; NANCE; SANDERS, 2007). Mais recentemente, vem sendo descrito outro mecanismo envolvendo o Sistema Nervoso Parassimpático denominado de Via Colinérgica Antiinflamatória que controla principalmente a resposta inflamatória de forma reflexa e não consciente (TRACEY, 2002, 2007).

O principal regulador do efeito dos glicocorticóides sobre o sistema imune é o eixo hipotálamo-hipófese-adrenal, classicamente conhecido como eixo HPA, tendo como seus principais componentes o Núcleo Paraventricular do hipotálamo, a glândula hipófise e a glândula adrenal, que levam em última instância à liberação de glicocorticóides na circulação (WEBSTER; TONELLI; STERNBERG, 2002). Assim, 
por exemplo, estados de medo, ansiedade e depressão, que estão ligados a um aumento da atividade do eixo HPA, têm sido correlacionados a um déficit pronunciado de imunidade, em especial, do número de células esplênicas, da proliferação de linfócitos $\mathrm{B}$, linfócitos $\mathrm{T}$ helper e $\mathrm{T}$ citotóxico, da atividade e número de células natural killer (NK) e da atividade de macrófagos (PALERMO NETO; MASSOCO; FAVARE, 2001; PALERMO-NETO; DE OLIVEIRA MASSOCO; ROBESPIERRE DE SOUZA, 2003; SA-ROCHA; SA-ROCHA; PALERMO-NETO, 2006). Os glicocorticóides naturais e sintéticos inibem a proliferação de células $T$ estimuladas por mitógenos e por aloantígenos in vitro através da ligação com receptores de glicocorticóides citoplasmáticos presentes em linfócitos $T$ e $B$, e em macrófagos (MADDEN; FELTEN, 1995). Por outro lado, a presença de macrófagos pode modificar as reações das células $\mathrm{T}$ aos glicocorticóides; neste sentido, mostrou-se que a adição de glicocorticóides inibiu a atividade de células $\mathrm{T}$; no entanto, quando os macrófagos ativados e/ou seus produtos estavam presentes, preveniu-se a supressão da atividade de células $\mathrm{T}$ mediada pelos glicocorticóides (BRADLEY; MISHELL, 1981; MADDEN; FELTEN, 1995).

Neste sentido, os glicocorticóides induzem uma mudança do perfil de citocinas Th1 para um perfil de citocinas Th2. A imunidade Th1 (Imunidade Celular) é caracterizada pela expressão de citocinas pró-inflamatórias, tais como Interferon (IFN)- $\gamma$, IL-2 e Fator de Necrose Tumoral (TNF)- $\alpha$, resultando em uma diferenciação de macrófagos, células NK e células T citotóxicas, que estão envolvidas na fagocitose e destruição de bactérias invasoras ou corpos estranhos. A imunidade Th2 (Imunidade Humoral) é caracterizada pela produção de citocinas antiinflamatórias, tais como IL-4, IL-10 e IL-13, resultando na diferenciação de eosinófilos, mastócitos e células $\mathrm{B}$, que leva a uma defesa a antígenos mediada por anticorpos (WEBSTER; TONELLI; STERNBERG, 2002). Neste contexto, acredita-se que a mudança de perfil de citocinas induzida pelos glicocorticóides seja conseqüência de uma regulação negativa das citocinas Th1, assim permitindo a expressão dominante de citocinas Th2 (FRANCHIMONT et al., 2000; AGARWAL; MARSHALL, 2001). Os glicocorticóides controlam a expressão de IL-12 e/ou de seu receptor, e esta regulação parece ser o mecanismo principal pelo qual eles medeiam a mudança no perfil das citocinas (ELENKOV; CHROUSOS, 1999). De fato, os glicocorticóides inibem a produção aguda de citocinas de perfil Th1 e Th2 mas, em última instância, o que fazem é favorecer uma mudança para um padrão de 
diferenciação de perfil Th2 (LIBERMAN et al., 2007b). Acredita-se que este desbalanço aconteça porque os glicocorticóides ativam os receptores de glicocorticóides que bloqueiam a atividade transcricional de T-bet, o principal fator de transcrição envolvido na imunidade celular (Th1), pelo mecanismo de transrepressão, descrito acima (LIBERMAN et al., 2007a). Além disso, os glicocorticóides inibem o RNAm, a expressão de proteínas e a ativação transcricional de GATA-3, o fator de transcrição chave envolvido na resposta imune humoral (Th2). Esses efeitos ocorrem através de uma inibição da fosforilação de GATA-3 via PKA/p38 MAPK induzida por AMPc (LIBERMAN et al., 2009). A maior sensibilidade de inibição de T-bet com relação à GATA-3 ajuda a entender a indução do perfil Th-2 exercido pelos glicocorticóides, principalmente após um estresse crônico ou tratamentos prolongados com glicocorticóides exógenos (LIBERMAN et al., 2009).

A respeito das ações que o sistema nervoso simpático exerce sobre as funções imunes tanto na imunidade inata como na imunidade adquirida, os primeiros relatos foram publicados por Felten et al. (1985) a respeito da inervação catecolaminérgica do timo e do baço, e subseqüentemente de outros tecidos como linfonodos, intestino e medula óssea. Após esse trabalho pioneiro, deu-se início às buscas pelos mecanismos neuroimunes através dos quais o sistema nervoso simpático modulava diversos parâmetros imunológicos. Na esfera da imunidade inata, a noradrenalina pode inibir drasticamente a produção e secreção de TNF (IGNATOWSKI; GALLANT; SPENGLER, 1996). Além disso, após um estímulo estressor (choque nas patas, por exemplo) os níveis plasmáticos e esplênicos de TNF de animais estimulados com lipopolissacarídeo (LPS) foram suprimidos (MELTZER et al., 2004). Na esfera da imunidade adquirida, assim como os glicocorticóides, as catecolaminas podem dirigir a resposta Th2 em detrimento daquelas do tipo Th1. A noradrenalina e a adrenalina ex vivo foram capazes de inibir a produção de IL-12 e de aumentar a produção de IL10 em uma cultura de sangue total estimulada com LPS, sendo a ligação das catecolaminas a receptores $\beta_{2}$-adrenérgicos responsáveis por estes efeitos tanto nas células apresentadoras de antígeno (APC) como nas células Th1 (ELENKOV et al., 1996).

Com relação à modulação sistema imune $\rightarrow$ SNC, evidências iniciais mostraram que produtos de células imunes afetam mecanismos neuro-endócrinos. A administração do sobrenadante obtido de cultura de linfócitos de roedores estimulados por mitógenos, produzia aumento da liberação de ACTH (hormônio 
adenocorticotrópico) e de corticosterona. Posteriormente, utilizando-se interleucina (IL)-1 recombinante purificada, observou-se que esta citocina estimulava de maneira similar a liberação de ACTH e de corticosterona em ratos (BESEDOVSKY; DEL REY, 1996).

Neste sentido, uma série de sinais e sintomas relacionados ao processo infeccioso, tais como diminuição da atividade locomotora, anedonia, perda do apetite e déficit cognitivo, entre outros, estão relacionados ao denominado comportamento doentio. Citocinas pró-inflamatórias, como IL-1ß e TNF têm sido consideradas como os principais responsáveis por estas profundas alterações sobre o comportamento (DANTZER et al., 2008).

Dados de literatura mostram que o cérebro não é um órgão imunoprivilegiado e, atualmente, sabe-se que o sistema imune sinaliza a ocorrência de um processo inflamatório/infeccioso por diversas vias: (1) citocinas produzidas no foco da infecção sinalizam via nervos aferentes, tais como o nervo vago (infecções abdominais e viscerais) e o nervo trigêmeo (infecções oro-linguais); (2) células semelhantes a macrófagos nos órgãos circuventriculares e no plexo coróide que respondem às citocinas circulantes, por sua vez produzem citocinas que adentram no cérebro por difusão; (3) transporte ativo de citocinas via transportadores presentes na barreirahemato-encefálica; e (4) presença de receptores de IL-1ß em macrófagos perivasculares e em células endoteliais das vênulas cerebrais, sendo que a ativação desses receptores resulta na produção local de prostaglandina E2. Assim, mostrouse, utilizando animais knockout, que a liberação, na periferia e/ou no SNC, de IL-1 induzidas por LPS, tem papel central no aparecimento do comportamento doentio (BLUTHE et al., 2000a,b).

Em nossos laboratórios, foram realizados ensaios para analisar os efeitos de doenças em respostas neuroendócrinas e comportamentais. Utilizando-se modelos experimentais de reação alérgica intestinal foi demonstrado em camundongos um aumento dos níveis de ansiedade medidos no campo aberto e no labirinto em cruz elevado e um aumento na expressão de c-Fos no núcleo paraventricular do hipotálamo e no núcleo central da amígdala (BASSO et al., 2003). Adicionalmente, em um modelo de alergia pulmonar mostrou-se que animais que haviam sido previamente imunizados com ovalbumina (OVA), apresentavam um aumento de aversão ao lado escuro de uma caixa de esquiva passiva após associação deste lado com uma nebulização com OVA; esses animais mostraram, ainda, um aumento 
da atividade de células do núcleo ventromedial do hipotálamo e da região basolateral da amígdala (COSTA-PINTO et al., 2005). Mostrou-se, também, que a remoção de $\lg \mathrm{E}$ (por depleção do anticorpo utilizando um anti-lgE) preveniu estes efeitos (COSTA-PINTO et al., 2006). Em outro trabalho, relatou-se que animais tratados no período neonatal com capsaícina (neurotoxina capaz de promover um déficit nas modalidades sensoriais eliciadas pelas fibras nervosas do tipo $\mathrm{C}$ ), apresentaram uma diminuição na expressão de c-Fos no núcleo do trato solitário e um bloqueio completo na expressão desta proteína no núcleo paraventricular do hipotálamo, fatos que sugerem ter as fibras nervosas do tipo $\mathrm{C}$ um papel importante nos mecanismos ligados a estas manifestações neuroimunes (BASSO et al., 2004).

Não se pode deixar de comentar que uma das descobertas mais notáveis da biologia foi o compartilhamento bioquímico entre o sistema nervoso e o sistema imune, finalmente caracterizando as bases moleculares da interação imune-neuroendocrina (BLALOCK; SMITH, 1980). Foram Blalock e Smith (1980) que primeiramente mostraram serem os leucócitos capazes de produzir um peptídeo, com características semelhantes ao liberado pela hipófise, identificado posteriormente como sendo o ACTH. A partir deste marco, foram estabelecidas as bases moleculares para a interação entre os sistemas imune e neuroendócrino, tendo-se mostrado a expressão de receptores para hormônios, neurotransmissores e neuropeptídeos, assim como seus ligantes, em células do sistema imune; mostrouse, também, que citocinas produzidas por células do SNC estimulavam a comunicação neuronal (SMITH; BLALOCK, 1988). De fato, sabe-se hoje que produtos do sistema imune e do eixo neuro-endócrino coexistem em tecidos linfóide, endócrino e neural. Hormônios, neurotransmissores e neuropeptídeos afetam o sistema imune, assim como produtos de células imunes e originados de processos inflamatórios, como interleucinas e prostaglandinas, afetam mecanismos neuroendócrinos (BESEDOVSKY; DEL REY, 1996).

Blalock (1984) propôs que o sistema imune, além da sua função na defesa do organismo, atuaria como um órgão sensorial especial; servindo neste caso, para detectar estímulos que não poderiam ser ouvidos, vistos, cheirados, degustados ou sentidos (BLALOCK, 1984). Especificamente, ele sugeriu que o sistema imune poderia funcionar como um "Sexto Sentido" capaz de detectar e levar o organismo a responder a organismos invasores tais como patógenos ou à presença de tumores ou alérgenos. Por ter grande sensibilidade e especificidade sabe-se hoje que esse 
"órgão sensorial", mobiliza o corpo a responder prontamente a esses desafios; esta capacidade sensorial tem seu fundamento nas bases moleculares das interações entre os sistemas imune e neuroendócrino já que os leucócitos individualmente não estão diretamente conectados ao SNC (BLALOCK, 2005).

Esta distribuição ubíqua de receptores e seus ligantes é de vital importância para o estabelecimento da comunicação bidirecional entre estes grandes sistemas. O Sistema Endocanabinóide se encaixa perfeitamente no contexto das bases moleculares das interações imune-neuro-endócrinas. Vem sendo demonstrado que o sistema endocanabinóide tem um amplo espectro de influências sobre os circuitos neuronais excitatório e inibitório, principalmente devido à larga distribuição dos receptores canabinóides (CB1 e CB2) em áreas vitais do SNC (RODRIGUEZ DE FONSECA et al., 2005). Esse sistema é conhecido por regular uma série de funções fisiológicas tais como o movimento, a memória e o aprendizado, a cognição, o apetite, a emese, a temperatura corporal, a dor, o comportamento e a secreção neuroendócrina (CROXFORD; YAMAMURA, 2005). Neste sentido, já foi descrita a presença de ligantes e receptores canabinóides (CB1 e CB2) em leucócitos e tecidos linfóides e, desta forma, vem sendo demonstrado que os (endo)canabinóides são capazes de modular a atividade do sistema imune (KLEIN et al., 2003).

A existência do sistema endocanabinóide começou a ser desvendada quando foi determinada e caracterizada a presença de um receptor canabinóide (CB1) no cérebro de ratos (DEVANE et al., 1988; MATSUDA et al., 1990). A partir desta descoberta foi demonstrado que esses receptores estão amplamente distribuídos por todo o SNC sendo o subtipo de receptor CB1 aquele com a maior expressão, entre todos os receptores ligados à proteína $\mathrm{G}$ em todo o cérebro (HERKENHAM et al., 1991; MAILLEUX; VANDERHAEGHEN, 1992; GLASS; DRAGUNOW; FAULL, 1997). De fato, o receptor CB1 está presente em todas as regiões do SNC incluindose aqui o neocórtex, o hipocampo, o cerebelo, os gânglios da base, a amígdala, o tronco encefálico, o hipotálamo e a pituitária (HASHIMOTODANI; OHNO-SHOSAKU; KANO, 2007). Fora do SNC, o receptor CB1 também está expresso no coração, fígado, rins, baço, células imunes, intestino, testículos e ovários (PERTWEE, 1997); estando expresso também em células do sistema imune, apresentando-se aqui uma expressão menor que aquela do receptor CB2 (KLEIN; NEWTON; FRIEDMAN, 1998). Neste sentido, devido à expressão predominante de receptor CB1 no SNC, 
ele é geralmente referido como o receptor canabinóide cerebral (BREIVOGEL; CHILDERS, 1998).

Em um segundo momento, foi caracterizado na periferia (macrófagos e baço) um segundo tipo de receptor canabinóide, o receptor CB2 (MUNRO; THOMAS; ABU-SHAAR, 1993). Mostrou-se em especial a expressão predominante deste receptor em células $B$, células $T$ e macrófagos, assim como no baço e no timo de camundongos (SCHATZ et al., 1997). O receptor CB2 foi descrito por muito tempo como sendo o receptor canabinóide periférico. Mostrou-se que as subpopulações celulares do sangue humano apresentam diferentes graus de expressão de receptores $\mathrm{CB} 2$, como segue: células $\mathrm{B}>$ células $\mathrm{NK}>$ monócitos > neutrófilos > células T CD8 > células T CD4 (GALIEGUE et al., 1995). Os dados de literatura ainda apresentam controvérsias a respeito da expressão de receptores CB2 no SNC. Há dados substanciais indicando a expressão de receptores CB2 na microglia e o aumento da sua expressão em condições neuroinflamatórias, inflamação periférica e nocicepção (ATWOOD; MACKIE, 2010). No entanto, não haviam evidências indicativas de expressão de receptores CB2 em neurônios. Atualmente, alguns trabalhos conseguiram mostrar pequenas quantidades deste receptor expressas em áreas como: tronco encefálico, cerebelo, córtex, hipocampo, tálamo, hipotálamo, dentre outros, e ainda que, em determinadas condições, a expressão deste receptor está aumentada (ATWOOD; MACKIE, 2010).

Os receptores canabinóides pertencem a uma família de receptores que têm sete domínios transmembrana e que são acoplados à proteína G; portanto, estão ligados à inibição da adenilato ciclase e, conseqüentemente, à inibição do acúmulo de AMPc. Os efeitos que produzem são bloqueados pela ação da toxina pertussis indicando que a proteína $G$ que está acoplada a esses receptores é do tipo $\mathrm{G}_{\mathrm{i} / 0}$. Esses receptores também estão acoplados à ativação do canal de potássio e à inibição do canal de cálcio do tipo $\mathrm{N}$ e do tipo $\mathrm{Q}$ (também sensíveis à ação da toxina pertussis) e estas ações são relevantes para o papel neuromodulador dos canabinóides na liberação de neurotransmissores (RODRIGUEZ DE FONSECA et al., 2005).

A descoberta destes receptores levou, naturalmente, à procura por endocanabinóides no organismo. $\mathrm{O}$ primeiro endocanabinóide, a $\mathrm{N}$ araquidoniletanolamida (AEA ou anandamida), foi identificado em 1992, no cérebro de suínos e verificou-se que essa molécula deslocava a ligação específica de um 
agonista canabinóide do receptor canabinóide CB1 (DEVANE et al., 1992). A anandamida é biosintetizada a partir de lipídios de membrana pela ação enzimática da N-acil transferase e pela fosfolipase D (FREUND; KATONA; PIOMELLI, 2003); ela é encontrada no cérebro, em células do sistema imune, no plasma, em órgãos linfóides secundários como o baço e em tecido periféricos como o coração (RODRIGUEZ DE FONSECA et al., 2005). Um segundo endocanabinóide, o 2Araquidonilglicerol (2-AG) foi isolado em seqüência no intestino de cães (MECHOULAM et al., 1995). O 2-AG é, também, produzido a partir de lipídios de membrana principalmente pela ação das enzimas fosfolipase $\mathrm{C}$ e diacilglicerol lípase (FREUND; KATONA; PIOMELLI, 2003), sendo, também, encontrado no cérebro, em células do sistema imune, no plasma, em órgãos linfóides secundários como o baço e em tecidos periféricos (RODRIGUEZ DE FONSECA et al., 2005). Estes endocanabinóides, a anandamida e o 2-AG, são metabolizados por enzimas intracelulares e são hidrolizados pela fatty acid amide hydrolise (FAAH) e pela monoacilglicerol lípase (MAGL), respectivamente (HASHIMOTODANI; OHNOSHOSAKU; KANO, 2007).

Várias evidências têm levantado a possibilidade de um papel dos endocanabinóides como neuromoduladores; essas substâncias funcionariam como mensageiros retrógrados em sinapses no SNC (HASHIMOTODANI; OHNOSHOSAKU; KANO, 2007). Sabe-se, a esse respeito, que os canabinóides endógenos são liberados de acordo com a demanda após a despolarização neuronal. Uma vez liberados, atuam em receptores canabinóides localizados em neurônios situados pré-sinapticamente e ao redor do sítio de sua produção. No SNC, a distribuição altamente organizada destes elementos de sinalização em sinapses GABAérgicas, dopaminérgicas, glutamatérgicas; sua preservação, ao longo da evolução, sugere um papel relevante dos mesmos na transmissão sináptica.

Por outro lado, a ativação de células imunes induz um aumento na expressão tanto de receptores CB1 como CB2 presentes nestas células; consequentemente, esses receptores estariam envolvidos com os processos de ativação e, também, com a regulação das respostas imunológicas. Outra evidência que suporta este conceito é a de que células imunes, principalmente macrófagos, liberam metabólitos do ácido araquidônico quando estimulados. De forma interessante, um dos metabólitos liberados é a anandamida, sugerindo esse fato que células imunes ativadas respondam através da liberação de endocanabinóides. Assim, essas 
moléculas poderiam atuar de forma parácrina e, também, autócrina o que sugere a existência de mecanismos imunoregulatórios (KLEIN et al., 2003).

Mais importante que somente o compartilhamento de receptores e ligantes, é o fato de que se começa a demonstrar a importância do sistema endocanabinóide na sinalização de respostas periféricas para o SNC. Foi recentemente demonstrado que o controle de ingestão de alimentos gordurosos é dependente da ativação do sistema endocanabinóide (DIPATRIZIO et al., 2011). A ingesta de alimento gorduroso gera uma mobilização de endocanabinóides, anandamida e 2-AG, principalmente, e uma diminuição da atividade das enzimas de degradação dessas moléculas. De maneira interessante, mostrou-se o aumento da oferta de endocanabinóides e a ativação do receptor CB1 presente no intestino, geram uma sinalização aferente ao cérebro, via nervo vago, aumentando a necessidade da ingesta de alimentos gordurosos (DIPATRIZIO et al., 2011). Obviamente, esta constatação não modifica ou indica que os sistema endocanabinóide esteja envolvido nas interações neuroimunes, seja "de cima para baixo" ou "de baixo apra cima”. Não obstante, esses novos dados de literatura levantam algumas perguntas.

Estaria o sistema endocanabinóide envolvido na sinalização periférica do sistema imune em órgãos como intestino, pulmão, baço, etc, para o sistema nervoso? É sabido que diversas funções fisiológicas são controladas pelo sistema endocanabinóide, como as respostas a estímulos estressores, assim como ativação do eixo HPA e do sistema nervoso autônomo; sabe-se também, que essas funções fisiológicas modulam as respostas imunológicas. Portanto, qual seria a participação do sistema endocanabinóide na modulação exercida pelo SNC nas respostas imunológicas periféricas? Atualmente, tem sido discutido e demonstrado um papel da microglia nas interações neuroimunes (LIU; TANG; FENG, 2011); tem-se demonstrado, também, que o sistema endocanabinóide tem papel fundamental na atividade das células da microglia (STELLA, 2009). Desta forma, o sistema endocanabinóide controlaria as respostas neuroimunes pela sua capacidade de modular a liberação de neurotransmissores ou, então, essa capacidade estaria intrinsicamente relacionada à atividade das células da microglia?

Apesar de não terem sido o foco do nosso trabalho, todas essas perguntas ainda continuam sem resposta, no entanto, já é chegada a hora de se começar um estudo mais aprofundado do sistema endocanabinóide e, em especial, de seu papel nas interações neuroimunes. 


\subsection{Canabidiol}

O cannabidiol (CBD) pode ser considerado um velho canabinóide derivado da Cannabis sativa, mais popularmente conhecida como maconha. $O$ isolamento do CBD, o principal canabinóide não-psicotrópico da maconha, aconteceu em 1940 (ADAMS; HUNT; CLARK, 1940) e a caracterização da sua estrutura molecular ocorreu em 1963 (MECHOULAM; SHVO, 1963). Mesmo após a caracterização de sua estrutura molecular, poucos estudos farmacológicos foram realizados utilizando o CBD. Na década de 70 o grupo do Prof. Dr. Carlini foi responsável por um considerável número de publicações avaliando os efeitos anti-epiléticos do CBD e, também, os efeitos da interação do CBD com o $\Delta 9$-Tetrahidronabinol (THC) (CARLINI et al., 1973; KARNIOL; CARLINI, 1973), o principal canabinóide psicotrópico extraído da maconha. No entanto, era notório que o CBD não apresentava efeitos farmacológicos similares aos do THC, o que gerou desinteresse da comunidade científica nesta molécula. Somente quando se descobriu o sistema endocanabinóide, no início da década de 90, foi que se começou a entender a diversidade de mecanismos de ação do CBD e, então, a partir dos anos 2000, um grande número de publicações apontom os potenciais efeitos terapêuticos desse fármaco (ZUARDI, 2008).

Retrospectivamente, antes da descoberta do sistema endocanabinóide, é interessante observar que White e Tansik (1980) mostraram que o CBD e, também, - THC aumentavam a atividade de fosfolipase A2 e inibiam aquelas da tromboxano sintase e da cicloxigenase, o que prenunciava a importância dos (endo)canabinóides no metabolismo e na regulação dos fosfolipídios de membrana e de seus efeitos anti-inflamatórios. Mostrou-se, alguns anos depois, que o CBD alterava a produção de citocinas de células mononucleares in vitro (WATZL; SCUDERI; WATSON, 1991). Quase uma década depois iniciou-se de forma mais efetiva os estudos sobre os efeitos anti-inflamatórios do CBD em modelos animais.

Estudos com inflamação crônica e autoimunidade, mostraram que o tratamento oral com CBD diminui a inflamação em um modelo murino de artrite induzida por colágeno (MALFAIT et al., 2000). Relatou-se que o CBD diminuiu a incidência e retardou o aparecimento de diabetes do tipo I em camundongos NOD (camundongos 
não obsesos que desenvolvem diabetes espontaneamente) (WEISS et al., 2006; WEISS et al., 2008); e ainda, que o CBD diminuiu o aparecimento de distúrbios relacionados à diabetes como a retinopatia (EL-REMESSY et al., 2006; LIOU et al., 2009) e cardiomiopatia (RAJESH et al., 2010) diabética. Além disso, mostrou-se que o CBD diminuiu a neuroinflamação e o início da doença em modelos experimentais de esclerose múltipla (BAKER; JACKSON; PRYCE, 2007; KOZELA et al., 2011).

Em um modelo de inflamação aguda, o edema de pata induzido por carragenina, mostrou-se que o CBD diminuiu de forma dose-dependente diversos parâmetros inflamatórios, tais como produção de prostaglandina E2, produção de óxido nítrico e atividade da cicloxigenase (COX) (COSTA et al., 2004). De especial importância para nosso trabalho, Carrier et al. (2006) mostraram que o CBD apresenta efeito anti-inflamatório aumentando a sinalização via receptor de adenosina. Mais especificamente, mostraram que o CBD aumenta a oferta extracelular de adenosina e que esse aumento era responsável pela diminuição na produção de TNF, em animais tratados com LPS, via receptor de adenosina A2A (CARRIER; AUCHAMPACH; HILLARD, 2006). Ainda, foi relatado que o CBD é capaz de atenuar o processo inflamatório seguido à isquemia-reperfusão cardíaca (DURST et al., 2007), cerebral (CASTILLO et al., 2010) e hepática (MUKHOPADHYAY et al., 2011). Por fim, alguns trabalhos tem demonstrado que o CBD tem um potencial efeito protetor em doenças inflamatórias intestinais (BORRELLI et al., 2009; JAMONTT et al., 2010).

Desta forma, dentre os canabinóides extraídos da Cannabis sativa, o CBD é o que apresenta maior potencial terapêutico, seja por seus efeitos descritos no SNC seja pelos efeitos que produz na periferia, especialmente em processos inflamatórios.

Diversos trabalhos tem demonstrado que 0 CBD apresenta potencial terapêutico no tratamento de doenças neurodegenerativas (Doença de Parkinson e Alzheimer), esquizofrenia e distúrbios de ansiedade, epilepsia, desordens do sono, isquemia cerebral e miocárdica, êmese, diabetes do tipo I e complicações da diabetes, câncer e dor (IZZO et al., 2009). Ainda, vem sendo demonstrado que o canabidiol apresenta um potente efeito anti-inflamatório, por diminuir diversos parâmetros da atividade imune inata.

O CBD é conhecido por exercer seus efeitos farmacológicos por uma diversidade de mecanismos de ação. Um trabalho de revisão relativamente recente 
mostra que já foram relatados ao menos 22 mecanismos de ação diferentes para os efeitos farmacológicos do CBD (IZZO et al., 2009). Dentre eles, a inibição da captação de adenosina, pela inibição competitiva de um transportador equilibrativo de adenosina, e sinalização via receptor de adenosina A2A parece ser o principal mecanismo responsável pelas ações anti-inflamatórias do CBD (CARRIER; AUCHAMPACH; HILLARD, 2006). Não se pode esquecer que o perfil farmacológico do CBD é complexo e que neste sentido, outros mecanismos, além da inibição da captação de adenosina, podem estar envolvidos com os efeitos anti-inflamatórios deste fármaco. Foi relatado que o CBD tem efeito de agonista inverso no receptor CB2 (THOMAS et al., 2007), inibição da captação e hidrólise enzimática da anandamida (BISOGNO et al., 2001), modulação alostérica positiva de receptores de glicina $\alpha 1$ e $\alpha 1 \beta$ (AHRENS et al., 2009), efeito agonista no receptor PPAR $\gamma$ (O'SULLIVAN et al., 2009), inibição da lipoxigenase 5 e 15 (MASSI et al., 2008; TAKEDA et al., 2009), e inibição da atividade da COX-2 e da óxido nítrico sintase induzida (iNOS) (CASTILLO et al., 2010). Cada um desses mecanismos descritos foi avaliado em diferentes tipos de modelos animais e linhagens celulares, o que implica dizer que não necessariamente todos eles estejam envolvidos de forma generalizada nas respostas inflamatórias em todas as espécies animais.

É compreensível que um farmacologista ao observar esta miríade de ações farmacológicas em diversos modelos animais, questione a possibilidade do uso de tal molécula na clínica. No entanto, é importante ressatar que o CBD se mostra extremamente seguro em humanos e vem sendo testado clinicamente, de forma preliminar, para o tratamento de desordens de ansiedade, psicoses e desordens do movimento. Há evidências pré-clínicas que permitem iniciar estudos em humanos no tratamento da diabetes, isquemia e câncer. Atualmente, um medicamento chamado de Sativex ${ }^{\circledR}$, a base de CBD e THC, vem sendo comercializado e utilizado na clínica em países como Reino Unido, Espanha, Alemanha, Dinamarca, Nova Zelândia e Canadá $\left({ }^{1}\right)$. As indicações do Sativex ${ }^{\circledR}$ são: espasticidade em pacientes com esclerose múltipla, dor em pacientes com câncer e dor neuropática, além de outras indicações tais como artrite reumatóide, disfunção urinária, anorexia e caquexia devido ao câncer e AIDS, e náuseas e vômitos em pacientes submetidos ao tratamento de quimioterapia. Desta forma, há evidências substanciais que suportam

\footnotetext{
${ }^{1}$ De acordo com a última consulta feita no dia 12/01/2012 no site ds empresa fabricante, GWPharma ( http://www.gwpharm.com/Sativex.aspx )
} 
o aprofundamento do estudo das ações do CBD em outros modelos animais e doenças.

Desde a descoberta do sistema endocanabinóide no início da década de 90, a busca pelos efeitos dos canabinóides, principalmente do CBD e do THC e de outros derivados da planta sobre a imunidade têm recebido grandes contribuições. No entanto, o potencial terapêutico anti-inflamatório do CBD em outros modelos de doença ainda carece de um maior aprofundamento.

A injúria pulmonar aguda $(A L I)$ e, sua forma mais severa, a síndrome do desconforto respiratório agudo (ARDS), são doenças pulmonares de início agudo, caracterizada por infiltrado pulmonar bilateral (GROMMES; SOEHNLEIN, 2011). A causa mais comum de ALI/ARDS em humanos é a sepsis, embora a seqüência exata de como isso ocorra não esteja muito bem elucidada. A ALI se caracteriza por uma injúria alvéolo-capilar e inflamação com acúmulo de neutrófilos e, também, produção de citocinas pró-inflamatórias (TSUSHIMA et al., 2009). A ALI pode resultar em falha respiratória persistente e dependência prolongada de ventilação mecânica, o que aumenta a susceptibilidade à falência múltipla de órgãos e mortalidade (RUBENFELD et al., 2005). Infelizmente, os tratamentos disponíveis para ALI e ARDS são apenas de suporte e terapias específicas ainda não foram desenvolvidas.

A ALI e a ARDS são ainda problemas de saúde pública, pois causa cerca de 200 mil hospitalizações e 75 mil mortes todos os anos nos Estados Unidos (RUBENFELD et al., 2005). No Brasil, há relativamente pouca informação a respeito da incidência de ALI/ARDS nas Unidades de Terapia Intensiva (UTI). Foi demonstrado em UTI's do Hospital das Clínicas de Porto Alegre uma incidência de 2,3\% de ARDS e 3,8\% de ALI (FIALKOW et al., 2002) e também no Hospital das Clínicas de Ribeirão Preto uma incidência de 2,3\% de ALI e 6,3\% de ARDS (OLIVEIRA; BASILLE FILHO, 2006).

Um aspecto interessante que acreditamos deve ser mencionado, é que dados de literatura tem apontado para um papel fisiológico exercido pela adenosina na resolução da ALI (ECKLE; KOEPPEN; ELTZSCHIG, 2009). De fato, há trabalhos mostrando que a concentração de nucleotídeos (ATP e ADP), precursores da adenosina, aumentam em modelos de ALI (CHEN et al., 2006). Juntamente com o aumento de nucleotídeos no pulmão, observaram-se um aumento da expressão das ectoenzimas (CD39 e CD73) que convertem o ATP/ADP em adenosina (ECKLE et 
al., 2007; REUTERSHAN et al., 2009). Neste sentido, a enzima CD39 converte o ATP/ADP em AMP, que por sua vez, é convertido em adenosina pela enzima CD73. Desta forma, seguindo-se a um aumento da liberação de nucleotídeos e das enzimas conversoras de nucleosídeos, observa-se um aumento na oferta extracelular de adenosia, o que sugere um papel importante dessas enzimas no modelo de ALI. Outro fator importante que dá suporte ao papel da sinalização de adenosina na resolução da ALI é a expressão de receptores de adenosina A2A e A2B nos pulmões (LUKASHEV et al., 2003). Desta forma, demonstrou-se a importância da sinalização via receptor de adenosina A2A (REUTERSHAN et al., 2007) e A2B (ECKLE et al., 2008) no modelo de ALI induzido por LPS. Da mesma maneira, trabalhos bastante recentes tem demonstrado o papel dos receptores $A 1$ (NGAMSRI et al., 2010) e A3 (WAGNER et al., 2010) nos efeitos anti-inflamatórios da sinalização da adenosina no modelo murino de ALI induzido por LPS.

Desta forma, imaginamos que o CBD, devido (1) à sua potente propriedade imunossupressora e antiinflamatória, e (2) ao seu característico mecanismo de ação (inibição da captação e aumento da oferta extracelular de adenosina), seria efetivo em diminuir a inflamação em um modelo de $A L I$ assim como tem sido relatado em outros modelos murinos de inflamação.

Decidimos, assim, estudar os efeitos do CBD em um modelo murino de Injúria Pulmonar Aguda (ALI), induzida pela administração intranasal de LPS (SZARKA et al., 1997), que é caracterizado pelo acúmulo de neutrófilos, edema, destruição da integridade epitelial e extravasamento de proteínas para o espaço alveolar (ZARBOCK et al., 2009). Avaliamos ainda se o mecanismo de ação envolvido no efeito anti-inflamatório do $C B D$ em nosso modelo estava relacionado à ativação do receptor de adenosina A2A. Conforme relatado anteriomente, sabe-se que a ativação do sistema imune na periferia leva à ativação de diversas áreas no sistema nervoso central e que esta ativação leva à mudanças comportamentais e neuroendócrinas. Desta forma, dentro de uma perspectiva neuroimunológica, buscamos integrar o conhecimento das interações imune-neuro-endócrina juntamente com os efeitos anti-inflamatórios do CBD. 


\section{OBJETIVOS}

\subsection{Objetivo geral}

Avaliar os efeitos anti-inflamatórios do CBD em um modelo murino de injúria pulmonar aguda (ALI), induzida pela administração intra-nasal de LPS, buscando integrar os efeitos farmacológicos anti-inflamatórios do CBD com o conhecimento das interações imune-neuro-endócrinas

\subsection{Objetivos específicos}

3.2.1 Em animais submetidos a um modelo de ALI, induzida pela administração intra-nasal de LPS, avaliar os efeitos do tratamento com CBD previamente à indução da inflamação sobre:

- a migração de leucócitos para os pulmões;

- a distribuição de leucócitos no sangue e na medula óssea;

- a atividade de mieloperoxidase (MPO) no tecido pulmonar;

- a produção de citocinas (TNF, IL-6, IL-12p70, IL-10, IFN- $\gamma$ ) e quimiocinas (MCP-1 e MIP-2) no lavado broncoalveolar (LBA);

- a concentração de albumina no LBA;

- a distribuição de células T regulatórias no LBA, no sangue e no baço;

- a atividade geral e locomotora no campo aberto;

- os níveis séricos de corticosterona. 
3.2.2 Em animais submetidos a um modelo de ALI, induzida pela administração intra-nasal de LPS, avaliar o mecanismo responsável pelos efeitos antiinflamatórios do CBD administrado previamente à indução da inflamação sobre:

- a migração de leucócitos para os pulmões;

- a distribuição de leucócitos no sangue e na medula óssea;

- a atividade de mieloperoxidase (MPO) no tecido pulmonar;

- a produção de citocinas (TNF, IL-6, IL-12p70, IL-10, IFN- $\gamma$ ) e quimiocinas (MCP-1 e MIP-2) no lavado broncoalveolar (LBA);

- a concentração de albumina no LBA.

3.2.3 Em animais submetidos a um modelo de ALI, induzida pela administração intra-nasal de LPS, avaliar os efeitos do tratamento com CBD posteriomente à indução da inflamação sobre:

- a migração de leucócitos para os pulmões;

- a distribuição de leucócitos no sangue e na medula óssea;

- a atividade de mieloperoxidase (MPO) no tecido pulmonar;

- a produção de citocinas (TNF, IL-6, IL-12p70, IL-10, IFN- $\gamma$ ) e quimiocinas (MCP-1 e MIP-2) no lavado broncoalveolar (LBA);

- a concentração de albumina no LBA;

- a expressão de moléculas de adesão (VLA-4 e ICAM-1) em leucócitos do LBA. 


\section{MATERIAIS E MÉTODOS}

\subsection{Animais}

Foram utilizados nos experimentos camundongos C57BL/6 machos advindos de nossa própria colônia, pesando aproximadamente 20-25 g e com 60 dias de vida. Camundongos machos C57BL/6 FoxP3-GFP (Green fluorescent protein) knockin advindos de nosso própria colônia, pesando aproximadamente $20-25 \mathrm{~g}$ e com 60 dias foram utilizados no experimento onde se avaliou a presença de células $T$ regulatórias (CD4+FoxP3+) no lavado broncoalveolar, no sangue e no baço (veja item 4.8). Os animais foram mantidos em salas com controle de temperatura (22 $24{ }^{\circ} \mathrm{C}$ ) e luz artificial, em um ciclo de $12 \mathrm{~h}$ claro/12 h escuro (luzes ligadas às $7 \mathrm{~h}$ ), com livre acesso a ração e água; como cama foi utilizada maravalha esterelizada. Os animais foram mantidos em suas caixas moradias por no mínimo 7 dias antes do início dos experimentos. Os camundongos foram mantidos e utilizados de acordo com as normas do Comitê de Bioética da Faculdade de Medicina Veterinária e Zootecnia da Universidade de São Paulo (Protocolo no. 2002/2010).

\subsection{Fármacos}

O canabidiol (THC-Pharm, Frankfurt, Germany e STI-Pharm, Brentwood, UK) foi preparado em uma solução de etanol:tween 20 :salina $0,9 \%$ (1:1:18), tendo sido administrado por via intraperitoneal (i.p.) nas doses de 0,3, 1,0, 10, 20, 30, 40, 80 $\mathrm{mg} / \mathrm{kg}(0,1 \mathrm{~mL} / 10 \mathrm{~g}$ de peso) em um primeiro experimento (item 5.1). Nos experimentos onde foi utilizado o protocolo de tratamento profilático foi utilizada a dose de $20 \mathrm{mg} / \mathrm{kg}$; sessenta minutos após o tratamento, os animais foram submetidos ao protocolo de indução da injúria pulmonar aguda. Nos experimentos onde foi utilizado o protocolo de tratamento terapêutico foram utilizadas as dose de 
20 e $80 \mathrm{mg} / \mathrm{kg}$; os animais foram submetidos ao protocolo de indução da injúria pulmonar aguda e $6 \mathrm{~h}$ após receberam o tratamento. Os animais dos grupos controle sempre receberam um volume similar de veículo, o mesmo utilizado para o preparo do canabidiol.

O ZM241385 (4-(2-[7-Amino-2-(2-furyl)[1,2,4]triazolo[2,3-a][1,3,5]triazin-5ylamino]ethyl)phenol) (Tocris Bioscience, Missouri, USA), um antagonista do receptor de adenosina A2A foi preparado em etanol:tween 20:salina 0,9\% (1:1:18), tendo sido administrado na dose de $5 \mathrm{mg} / \mathrm{kg}, 30$ minutos antes do tratamento com CBD; o diluente do mesmo foi administrado aos camundongos do grupo controle e tratados com CBD.

\subsection{Injúria pulmonar aguda}

Protocolo profilático: sesseta minutos após o tratamento com CBD os animais foram submetidos à instilação intra-nasal de LPS. Para tanto, os camundongos foram anestesiados com cetamina e xilazina (100 e $10 \mathrm{mg} / \mathrm{kg}$, i.p.). O LPS (Escherichia coli serotype 055:B5, Sigma St Louis, MO, USA) foi instilado por via nasal, em temperatura ambiente, na concentração de $100 \mu \mathrm{g} / \mathrm{ml}$ (após diluição em PBS), no volume de $1 \mu \mathrm{l} / \mathrm{g}$ de animal. A concentração e a via de administração do LPS baseiam-se nos estudos de Corteling et al. (2002). Após 1, 2, 4 e/ou 7 dias, os animais foram novamente anestesiados e submetidos à eutanásia por dessangramento através da artéria aorta abdominal; amostras necessárias para cada experimento como, por exemplo, de lavado broncoalveolar, de lavado femural, de sangue, do tecido pulmonar, do hipotálamo, etc, foram coletadas. Como grupo controle, foram utilizados animais submetidos à instilação intra-nasal de solução salina ( $\mathrm{NaCl}$ 0,9\%) apirogênica, nos mesmos volumes utilizados para o LPS.

Protocolo terapêutico: os animais foram, primeiramente, submetidos à instilação intra-nasal de LPS. Para tanto, os camundongos foram anestesiados com cetamina e xilazina (100 e $10 \mathrm{mg} / \mathrm{kg}$, i.p.), sendo o LPS instilado por via nasal, em temperatura ambiente, na concentração de $100 \mu \mathrm{g} / \mathrm{ml}$ (após diluição em PBS), no volume de $1 \mu \mathrm{l} / \mathrm{g}$ de animal. Decorridas $6 \mathrm{~h}$, os animais foram tratados com CBD e 
após 1 e 2 dias da indução da inflamação, foram novamente anestesiados e submetidos à eutanásia por dessangramento através da artéria aorta abdominal; amostras necessárias para cada experimento como, por exemplo, de lavado broncoalveolar, de lavado femural, de sangue, do tecido pulmonar, etc, foram coletadas. Como grupo controle, foram utilizados animais submetidos à instilação intra-nasal de solução salina ( $\mathrm{NaCl}$ 0,9\%) apirogênica, nos mesmos volumes utilizados para o LPS.

\subsection{Distribuição de leucócitos}

\subsubsection{Lavado broncoalveolar (LBA)}

O LBA foi coletado 1, 2, 4 e 7 dias após a instilação intranasal de LPS. Os animais foram mortos por exsanguinação feita pela veia cava inferior após anestesia i.p. com cetamina $(100 \mathrm{mg} / \mathrm{kg})$ e xilazina $(10 \mathrm{mg} / \mathrm{kg})$. Foi realizada uma incisão longitudinal na região cérvico-ventral, sendo a traquéia exposta e canulada com uma cânula metálica de 20 Gauge, fixada com fio de algodão ao redor da traquéia. A cânula foi acoplada a uma seringa contendo $0,8 \mathrm{ml}$ de PBS (tampão fosfato $\mathrm{pH} 7,4$ ) que foi injetado no espaço alveolar e, logo após, o lavado foi coletado em eppendorf. Após este procedimento, mais $0,7 \mathrm{ml}$ de PBS foi injetado no pulmão, sendo o lavado coletado, totalizando-se um volume de 1,5 $\mathrm{ml}$. Veja figura 1 abaixo. 

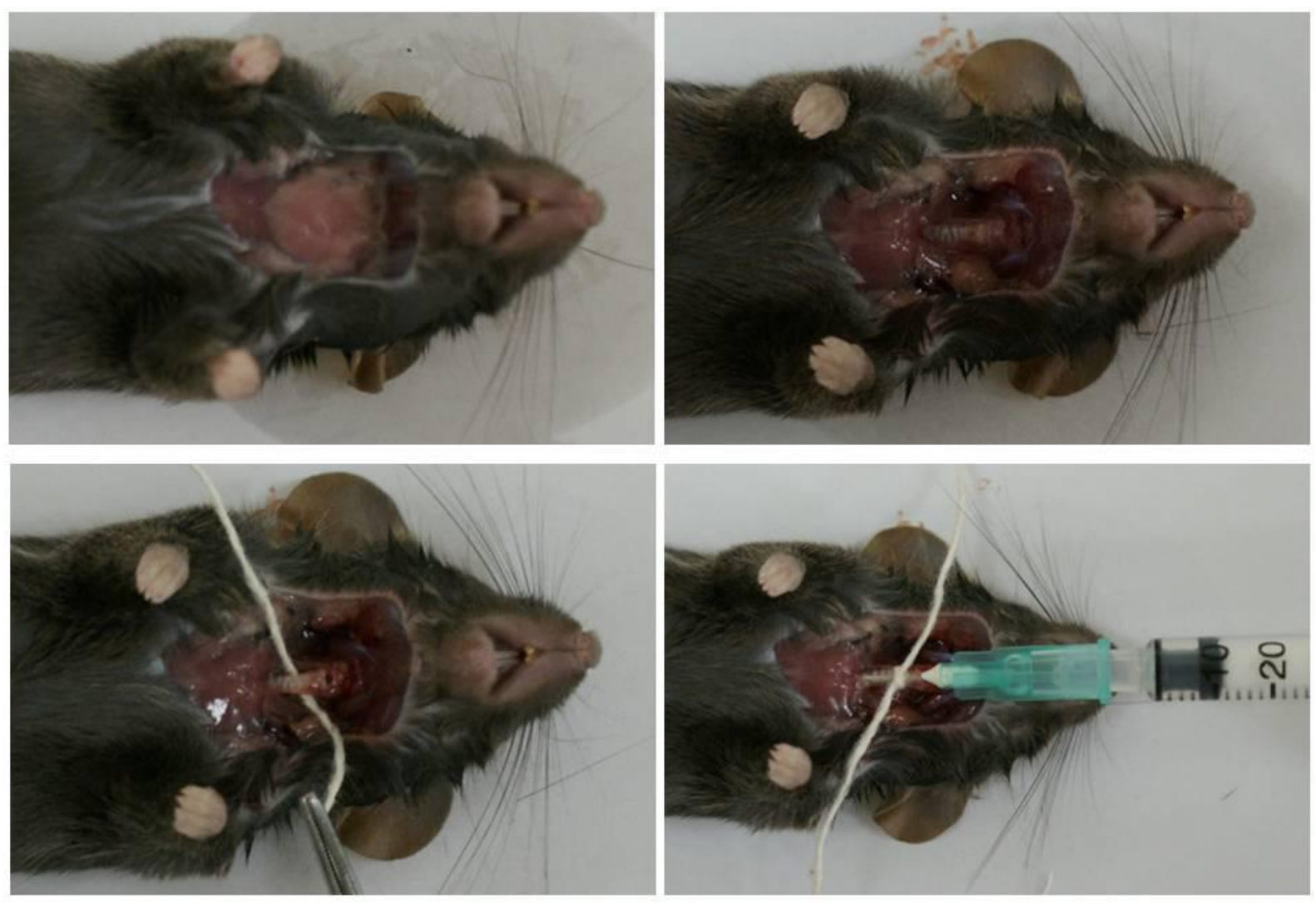

Figura 1 - Representação esquemática do procedimento de coleta de lavado broncoalveolar (LBA)

O LBA obtido foi centrifugado a $250 \times \mathrm{g}$ por $5 \mathrm{~min}$, sendo o sobrenadante coletado para dosagem de citocinas. $O$ botão celular foi ressuspenso em $1 \mathrm{~mL}$ de PBS e a contagem do número total de células no LBA foi realizada em câmara de Neubauer. Para tanto, alíquotas da amostra $(90 \mu \mathrm{l})$ foram acrescidas de $10 \mu \mathrm{l}$ de cristal violeta $0,2 \%$ dissolvido em ácido acético (30\%). Para a contagem diferencial, alíquotas da amostra $(100 \mu \mathrm{l})$ foram colocadas em citocentrífuga (FANEM, São Paulo, Brasil) e centrifugadas a $250 \times \mathrm{g}$ por 5 minutos. A contagem diferencial foi realizada por meio de colaração de Rosenfeld em microscopia óptica comum; foram contadas no mínimo 200 células, diferenciando-as morfológicamente em neutrófilos, macrófagos/monócitos e linfócitos. 


\subsubsection{Sangue}

Imediatamente antes da coleta do LBA, uma alíquota de sangue foi tomada da aorta abdominal de cada animal. Seringas de plástico de $1 \mathrm{~mL}$ foram utilizadas para a coleta de cada amostra e, em seguida, aproximadamente $200 \mu \mathrm{L}$ de sangue foi transferido para um eppendorf contendo $10 \mu \mathrm{L}$ de solução de EDTA $10 \%$. As amostras foram contadas em contador automático de células (ABC Vet ${ }^{\circledR}$, São Paulo, Brazil).

\subsubsection{Medula óssea}

O número total de células da medula óssea foi quantificado no lavado da medula do fêmur. Após a coleta do LBA e do sangue, o fêmur foi removido, tendo suas epífises sido cortadas transversalmente. Uma agulha conectada a uma seringa plástica contendo $5 \mathrm{~mL}$ de PBS foi, então, inserida na medula femoral e as células foram retiradas fisicamente e lavadas. A suspensão celular foi centrifugada $(250 \times \mathrm{g}$ por $5 \mathrm{~min}$ ) e o "pellet" celular foi ressuspenso e analisado. A contagem do número total de células foi realizada em câmara de Neubauer e em microscópio óptico comum, utlizando-se como corante o azul de tripan.

\subsection{Atividade da mieloperoxidase (MPO)}

Os animais foram anestesiados com cetamina e xilazina (100 e $10 \mathrm{mg} / \mathrm{kg}$, i.p.), submetidos a laparotomia mediana e dessangrados pela aorta abdominal. A cavidade torácica foi aberta e o leito vascular pulmonar perfundido com $10 \mathrm{~mL}$ de 
PBS por meio de uma cânula inserida na artéria pulmonar. Uma fração do pulmão foi coletada, pesada e guardada em freezer $-80^{\circ} \mathrm{C}$ até 0 momento da análise. As amostras foram preparadas de acordo com Golblum et al. (1985). Brevemente, a fração do pulmão foi homogeneizada em $1 \mathrm{~mL}$ de PBS contendo $0,5 \%$ de bromidrato de hexadeciltrimetilamonia (HTBA) e EDTA $5 \mathrm{mM}$, pH 6,0. As amostras homogeneizadas foram centrifugadas a $30.000 \times \mathrm{g}$ por 15 min a $4^{\circ} \mathrm{C}$ e $\mathrm{o}$ sobrenadante obtido foi utilizado para determinar a atividade de MPO na amostra. Para isto, o homogenato do pulmão $(10 \mu \mathrm{L})$ foi incubado por 5 min com $200 \mu \mathrm{L}$ uma solução contendo $\mathrm{H}_{2} \mathrm{O}_{2}(0,1 \%)$ e orto-dianisidina. A reação foi interrompida pela adição de $50 \mu \mathrm{L}$ de azida sódica (1\%). A absorbância foi determinada utilizando-se um leitor de microplacas a $450 \mathrm{~nm}$ (Bio-Tek Instruments ${ }^{\circledR}$, Winooski, USA). O calculo final da atividade de MPO foi normalizado dividondo-se os valores de absorbância pelo peso em gramas do tecido pulmonar.

\subsection{Análise de citocinas e quimiocinas}

Coletou-se uma alíquota de sangue da aorta abdominal de cada animal, utilizando-se seringas de plástico de $1 \mathrm{~mL}$; em seguida, o sangue foi transferido para um eppendorf seco, sendo centrifugado a $1000 \mathrm{xg}$ por 20 minutos. O soro obtido foi coletado e armazenado em freezer $-80^{\circ} \mathrm{C}$ até o momento das análises.

Foi utilizado o kit Cytometric Bead Array (CBA) Mouse Inflammation (BD Biosciences, San Jose, USA) para quantificar as concentrações de IL-6, IL-10, MCP1 , IFN- $\gamma$, TNF, e IL-12p70 no sobrenadante do LBA. O procedimento foi realizado de acordo com as intruções contidas no manual do fabricante. O CBA pode ser comparado ao método de ELISA sanduíche. De forma resumida, os nanobeads de captura, de detecção e as citocinas recombinantes da curva padrão específicos para cada citocina foram diluídas nas concentrações recomendadas. Cada nanobead está ligado a anticorpos específicos para a citocina/quimiocina a ser quantificada e apresenta tamanhos diferentes, o que permite a diferenciação de cada citocina, em diferentes picos de intensidade de fluorescência, como demonstrado na figura 2 abaixo. 

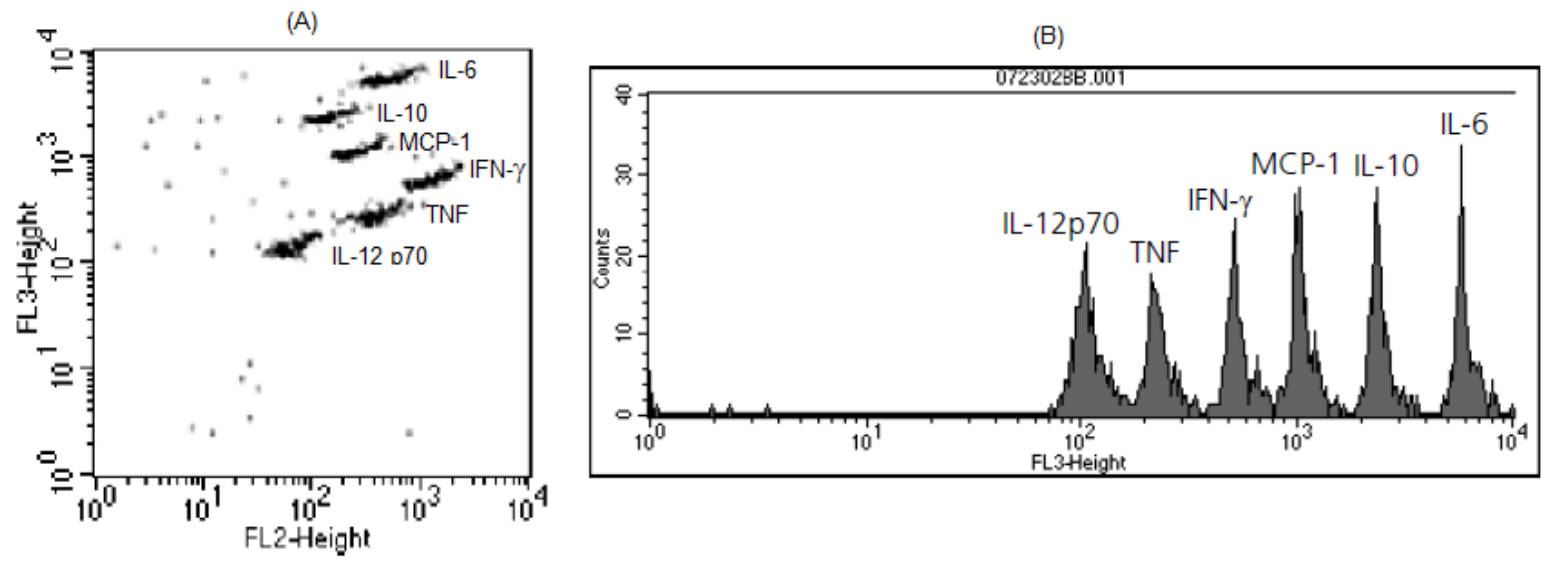

Figura 2 - (A) Citograma que ilustra as populações de nanobeads da curva padrão para as diferentes citocinas na concentração de $625 \mathrm{pg} / \mathrm{mL}$. (B) Histograma que ilustra os picos de intensidade de fluorescência para os diferentes populações de nanobeads. Figura adaptada do manual do usuário do CBA mouse inflammation kit - BD Biosciences

Os reagentes foram adicionados aos tubos de citometria relativos aos padrões e às amostras na seguinte ordem: suspensão de nanobeads de captura (50uL), padrões nas diferentes diluições e amostras (50uL) e os nanobeads de detecção (50uL); essa mistura ficou sob incubação por $2 \mathrm{~h}$ em temperatua ambiente no escuro. Após o período de incubação os tubos contendo os padrões e as amostras foram lavados (tampão de lavagem), sendo centrifugados a 250 x g por 5 minutos; o sobrenadante foi removido e as amostras foram ressupensas para leitura no citômetro de fluxo e determinação da intensidade de fluorescência de PE (detector FL2).

Foi utlizado o kit de ELISA (R\&D Systems, Minneapolis, USA) para quantificar a concentração de MIP-2 no sobrenadante do LBA. O procedimento foi realizado de acordo com as intruções contidas no manual do fabricante. Brevemente, os padrões e as amostras foram incubadas por um período de 2 horas em placas de 96 poços já sensibilizadas com anticorpos de captura, em temperatura ambiente. Após um ciclo de lavagem, adicionou-se em cada poço anticorpo de detecção conjugado com a enzima HRP (horseradish peroxidase) por um período de 2 horas, à temperatura ambiente. Novamente a placa foi lavada, adicionando-se o substrato da HRP em cada poço por $30 \mathrm{~min}$, protegido da luz, em temperatura ambiente. Por fim, a solução de parada $\left(\mathrm{H}_{2} \mathrm{SO}_{4} 2 \mathrm{~N}\right)$ foi adicionada para interromper a reação e a 
densidade óptica foi determinada em espectrofotômetro com filtro de $450 \mathrm{~nm}$.

\subsection{Análise de proteína (albumina) no LBA}

Alíquotas de LBA foram colocadas em microplacas de 96 poços (10 $\mu \mathrm{L} /$ poço), adicionando-se $250 \mu \mathrm{L}$ de reagente de Bradford a cada poço. Após $30 \mathrm{~min}$ de incubação à temperatura ambiente, a absorbância dos poços foi medida a $595 \mathrm{~nm}$ em leitor de microplaca. Foi utilizada uma curva padrão $(1,5-0,1 \mathrm{mg} / \mathrm{mL})$ de albumina sérica bovina (BSA, Sigma-Aldrich, St. Louis, USA) para determinação da concentração de proteína no LBA.

\subsection{Análise de células T regulatórias (CD4+FoxP3+)}

Foi utilizado um citômetro de fluxo (Becton Dickison Immunocytometry System, San Jose, CA, USA) conectado a um computador (Machintosh Apple, San Jose, CA, USA). Foram adquiridos 50000 eventos por meio de um programa denominado Cell Quest Pro ${ }^{\circledR}$ (Becton Dickison Immunocytometry System, San Jose, CA, USA). Estes eventos foram analisados por meio do programa FlowJo ${ }^{\circledR}$ versão 7.0.

As subpopulações celulares foram reconhecidas por meio das propriedades de FSC - Foward Scatter e SSC -Side Scatter que avaliam o tamanho e a complexidade das células, respectivamente. As fluorescências foram adquiridas em escala logarítmica para avaliação das moléculas de superfície celular e moléculas intracelulares (fenotipagem) de linfócitos. As amostras foram analisadas pelo uso do sofware FlowJo ${ }^{\circledR}$ a população de interesse (linfócitos T CD4+FoxP3+) foi delimitada meio de gates, excluindo-se assim outros tipos celulares das amostras. Além disso, o aparelho foi calibrado com um tubo branco (de animais com o mesmo background genético, porém sem a proteína verde knockin no gene FoxP3), um tubo de células (FoxP3 GPF knockin) sem marcação de superfície (fluorescência verde) e um tudo 
somente com marcação de superfície vermelha, anti-CD4-PE (de animais com o mesmo backgroud genético, porém sem a proteína verde knockin no gene FoxP3).

Foram coletados o LBA e o sangue, sendo eles processados conforme descrito no item 4.4. $O$ baço também foi coletado e submetido à fricção em placa de 6 poços contendo $5 \mathrm{~mL}$ de PBS gelado. Tanto a suspensão celular do baço quanto as células do sangue foram submetidas à lise hipotônica com soluções de $\mathrm{NaCl} 02 \%$ e 1,6\%. As células do LBA e do baço foram contadas e ajustadas para $1 \times 10^{6}$; do sangue total foram utilizados $100 \mu \mathrm{L}$ para a análise. As células foram marcadas em sua superfície com anticorpo anti-CD4 conjugado com PE. A fluorescência verde do GFP (green fluorescence protein) foi mensurada a $530 \pm 30 \mathrm{~nm}$ (detector FL1) e a fluorescência de cor vermelha PE (phycoerythrin) mensurada a $585 \pm 42 \mathrm{~nm}$ (detector FL2). A figura 3 que ilustra os dot plots utilizados nas análises.

A

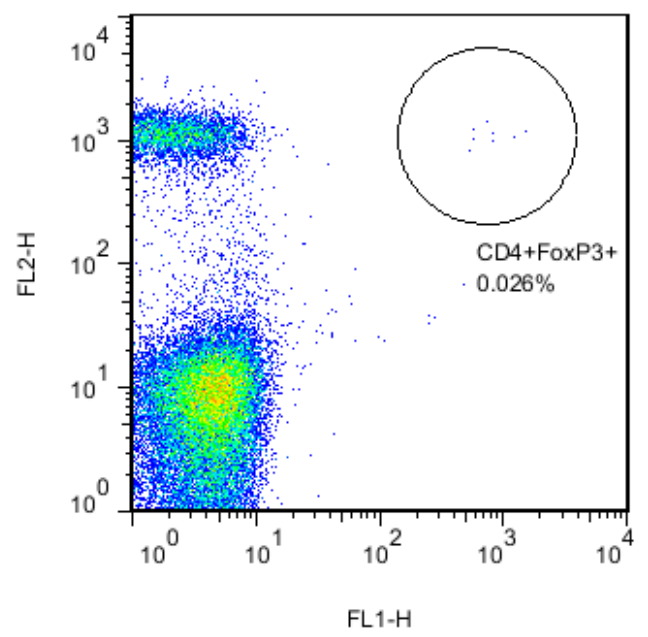

B

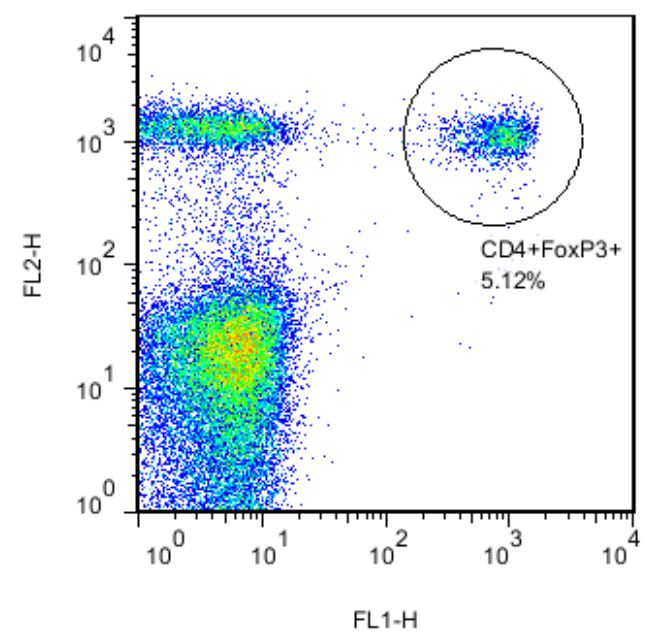

Figura 3 - Dot plots representativos utilizados na análise do percentual de células $T$ regulatórias (CD4+FoxP3+). (A) Dot plot de células T marcadas em sua superfície com anticorpo anti-CD4 conjugado com PE. (B) Dot plot de células $T$ regulatórias duplo-positivas para proteína verde fluorescente (FoxP3+) e marcadas em sua superfície com anticorpo anti-CD4 conjugado com PE 


\subsection{Expressão de moléculas de adesão em leucócitos do LBA}

Foi utilizado um citômetro de fluxo (Becton Dickison Immunocytometry System, San Jose, CA, USA) conectado a um computador (Machintosh Apple, San Jose, CA, USA). Foram adquiridos 50000 eventos por meio de um programa denominado Cell Quest Pro ${ }^{\circledR}$ (Becton Dickison Immunocytometry System, San Jose, CA, USA). Estes eventos foram analisados por meio do programa FlowJo ${ }^{\circledR}$ versão 7.0.

As subpopulações celulares foram reconhecidas por meio das propriedades de FSC - Foward Scatter e SSC -Side Scatter que avaliam o tamanho e a complexidade das células, respectivamente. As fluorescências foram adquiridas em escala logarítmica para avaliação das moléculas de superfície celular (fenotipagem) dos leucócitos. As amostras foram analisadas pelo uso do sofware FlowJo ${ }^{\circledR}$ a população de interesse (neutrófilos) foi delimitada meio de gates, excluindo-se assim outros tipos celulares das amostras.

O LBA foi coletado, sendo processado conforme descrito no item 4.4. As células do LBA foram contadas e ajustadas para $1 \times 10^{6}$; e foram marcadas em sua superfície com anticorpo anti-CD54 conjugado com PE (ICAM-1) e com anticorpo anti-CD49d conjugado com FITC (VLA-4). A fluorescência verde do FITC foi mensurada a $530 \pm 30 \mathrm{~nm}$ (detector FL1) e a fluorescência de cor vermelha do PE mensurada a $585 \pm 42 \mathrm{~nm}$ (detector FL2).

\subsection{Medida da atividade geral no campo aberto}

Para registro e análise comportamental foi utilizado o software Ethovision $\mathrm{XT}^{\circledR}$ (Noldus Information Technology ${ }^{\circledR}$, Leesburg, VA, USA) que consiste em um sistema de análise do movimento e reconhecimento comportamental. O sistema de observação indireta é constituído por uma filmadora instalada no teto de uma sala de observação. Os animais são posicionados no aparato e o seu comportamento é 
gravado para posterior análise no software. Para interpretar as imagens observadas durante a realização dos testes comportamentais no campo aberto o EthoVison XT versão 7.1 fez virtualmente as divisões do campo aberto em 2 áreas concêntricas (central e externa). Este sistema digitalizou e analisou o comportamento dos animais.

O campo aberto consiste de uma arena redonda feita de madeira, pintada de branco ( $40 \mathrm{~cm}$ de diâmetro e com paredes de $25 \mathrm{~cm}$ de altura, sendo o conjunto todo elevado a $55 \mathrm{~cm}$ do solo), como mostra a figura 4. Como já salientado, a atividade geral dos animais foi avaliada por meio do software Ethovision; desta forma, a presença do observador não interferiu com os parâmetros observados, uma vez que este ficou fora da sala onde se encontravam os animais em teste. É importante ressaltar que a sala onde foi realizado o experimento era pouco iluminada e protegida de qualquer tipo de ruído. Ainda, os animais dos diferentes grupos foram intercalados entre si para as observações afim de evitar possíveis interferências do ritmo circadiano sobre os resultados. Os animais foram colocados individualmente no centro da arena e observados por 5 minutos. A avaliação da atividade geral foi feita sempre no mesmo período do dia (entre as 7:00 hs e 12:00 hs) e, entre as observações, o aparelho foi limpo com uma solução aquosa de etanol $5 \%$, com a finalidade de se evitar a influência de odores.

Os parâmetros considerados indicativos da atividade geral no campo aberto foram os seguintes: 1) distância percorrida (cm): corresponde ao ato de o animal se locomover no piso da arena; 2) tempo (s) em movimento: quanto tempo o animal se movimentou no interior das zonas do campo aberto e 3) velocidade média $(\mathrm{cm} / \mathrm{s})$ : corresponde à distância percorrida pelo animal, por unidade de tempo. 


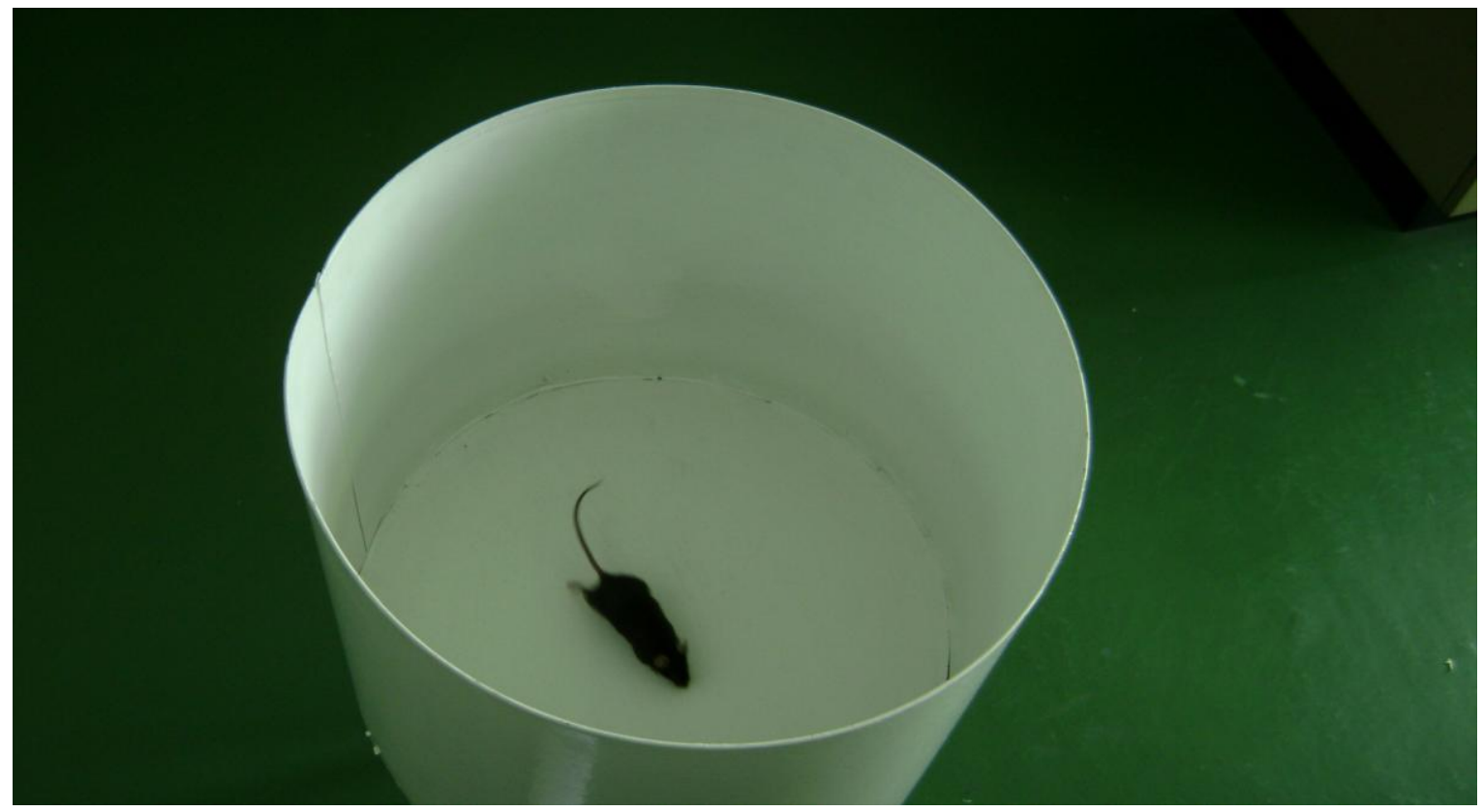

Figura 4 - Imagem do campo aberto utilizado na aquisição dos dados comportamentais

\subsection{Dosagem de corticosterona}

Os animais foram mortos por decaptação para a coleta de sangue e posterior obtenção do soro para a dosagem dos níveis séricos de corticosterona. O sangue foi coletado em eppendorfs secos 6 h e 24h após a indução da inflamação pulmonar, tendo sido deixado à temperatura ambiente para a retração do coágulo. Então, foi centrifugado a 1000 x g por 20 minutos para obtenção do soro. Este soro foi armazenado em eppendorfs de polietileno em freezer a $-80^{\circ} \mathrm{C}$ até o momento da realização das dosagens hormonais. As amostras foram coletadas à mesma hora do dia (entre 8 e $10 \mathrm{~h}$ am) buscando-se, desta forma, minimizar os efeitos do ritmo circadiano sobre os níveis séricos de corticosterona.

As amostras de soro dos animais foram retiradas do freezer, sendo mantidas à temperatura ambiente $\left(22 \pm 2^{\circ} \mathrm{C}\right)$ para o descongelamento. A quantificação de corticosterona foi realizada por ensaio imunoenzimático utilizando-se o kit comercial 
DetectX® (Arbor Assays, Michigan, USA) específico para corticosterona. 0 procedimento foi realizado de acordo com as intruções contidas no manual do fabricante. Brevemente, padrões e amostras diluidas foram colocados em placa de 96 poços, previamente coberta com anticorpos de captura. Um conjugado de peroxidase-corticosterona foi adicionado a cada poço e a reação de ligação é iniciada pela adição de anticorpo policlonal para corticosterona, também em cada poço. Após um período de incubação de $1 \mathrm{~h}$, a placa foi lavada com tampão de lavagem. O substrato da enzima foi, então, adicionado e mantido por um curto período de incubação (15 a 20 min), protegido da luz. A reação foi interrompida com a solução de parada. e a densidade óptica foi determinada em espectrofotômetro com filtro de $450 \mathrm{~nm}$.

\subsection{Análise estatística}

Os programas estatísticos GraphPad Prism 5.0 (GraphPad Softwares, Inc.) e SigmaPlot (Systat Software Inc.) foram utilizados nas análises estatísticas. Dados paramétricos foram analisados por ANOVA de uma via seguido do teste de comparações múltiplas Tukey-Kramer. Dados não paramétricos foram analisados pelo teste teste de Kruskal-Wallis seguido do teste de comparações múltiplas Dunn. Os dados de atividade de MPO e proteína no LBA foram analisados utilizando testes aplicados para dados não-paramétricos após terem sido normalizados como percentual do grupo controle não inflamado (veículo+sal). ANOVA de duas vias seguido do teste de Student-Newman-Keuls, quando necessário. Em todos os experimentos um $\mathrm{p} \leq 0.05$ foi considerado significante. Dados estão apresentados como media \pm erro padrão. 


\section{DELINEAMENTO EXPERIMENTAL E RESULTADOS}

\subsection{Tratamento profilático com CBD}

Decidimos iniciar nossos experimentos analisando os efeitos do tratamento profilático com CBD em um modelo murino de injúria pulmonar aguda (ALI).

5.1.1 O CBD tem um efeito anti-inflamatório dose-dependente em um modelo murino de $A L I$

Inicialmente, se fez necessária a realização de uma curva dose-resposta para avaliar os efeitos anti-inflamatórios do CBD no modelo ALI. Nossa intenção era eleger a menor dose com efeito anti-inflamatório em dois parâmetros genéricos de inflamação, sendo eles a migração total de leucócitos para os pulmões e a produção de TNF no LBA. Para tanto, quarenta e dois camundongos foram separados ao acaso em 9 grupos: veículo+sal, veículo+LPS, CBD 0,3+LPS, CBD 1,0+LPS, CBD 10+LPS, CBD 20+LPS, CBD 30+LPS, CBD 40+LPS, CBD 80+LPS. Brevemente, os animais receberam uma dose de CBD ou veículo (i.p.); 60 min após foram anestesiados e receberam solução salina ou LPS por via intra-nasal. Neste primeiro experimento realizamos a avaliação dos parâmetros inflamatórios $24 \mathrm{~h}$ após da indução da inflamação.

\section{RESULTADOS:}

A tabela 1 mostra os efeitos de doses crescentes de CBD na migração de leucócitos totais para os pulmões e na produção de TNF no LBA $24 \mathrm{~h}$ após a indução da inflamação. É importante observar que a instilação intra-nasal de LPS (veic+LPS) foi efetiva em induzir inflamação pulmonar, como pode ser observado 
pelo aumento do número de leucócitos $(F(8,33)=5,9 ; p<0,0001)$ (Figura 5A) e da concentração de TNF (F $(8,33)=7,8 ; p<0,0001)$ (Figura 5B) no LBA. Observamos que o tratamento com CBD, nas doses de 20 ( $p<0,05), 30(p<0,05)$ e $80(p<0,01)$ $\mathrm{mg} / \mathrm{kg}$, diminuiu a migração de leucócitos para os pulmões $(F(8,33)=5,9)$ (Figura 5A). Observamos, ainda, que o tratamento com CBD, nas doses de 10 ( $p<0,05), 20$ $(p<0,01), 30(p<0,05)$ e $80(p<0,0001) \mathrm{mg} / \mathrm{kg}$, diminuiu a produção de TNF no $\operatorname{LBA}(F(8,33)=7,8)($ Figura 5B).

Tabela 1 - Curva dose-resposta construída para avaliação dos efeitos do tratamento com CBD em um modelo murino de injúria pulmonar aguda (ALI)

\section{Parâmetros}

\begin{tabular}{|c|c|c|}
\hline Grupos & LBA (cél x 105) & TNF (pg/mL) \\
\hline Veículo + Sal & $0,9 \pm 0,1$ & $4,0 \pm 0,6$ \\
\hline Veículo + LPS & $5,0 \pm 0,7 a$ & $105 \pm 20 a$ \\
\hline CBD 0,3 + LPS & $4,5 \pm 0,9 a$ & $106 \pm 23 a$ \\
\hline CBD 1,0 + LPS & $4,1 \pm 0,4 a$ & $59 \pm 13$ \\
\hline CBD 10 + LPS & $2,9 \pm 0,6$ & $46 \pm 10 b$ \\
\hline CBD 20 + LPS & $2,3 \pm 0,5 \boldsymbol{b}$ & $31 \pm 13 b$ \\
\hline CBD 30 + LPS & $2,2 \pm 0,7 \boldsymbol{b}$ & $42 \pm 8 b$ \\
\hline CBD 40 + LPS & $2,7 \pm 0,6$ & $44 \pm 6$ \\
\hline CBD 80 + LPS & $1,6 \pm 0,4 \boldsymbol{b}$ & $15 \pm 6 b$ \\
\hline
\end{tabular}

Os dados representam a média \pm erro padrão, correspondente à contagem total de leucócitos no LBA (lavado broncoalveolar) e à concentração de TNF no sobrenadante do LBA. A letra a representa um $p<0,05$ quando comparado ao grupo veículo+sal e a letra $\boldsymbol{b}$ representa um $p<0,05$ quando comparado ao grupo veículo+LPS. Foi utilizado o teste estatístico ANOVA de uma via seguido do teste de Tukey-Kramer de comparações múltiplas, $n=4-5$ animais/grupo. 

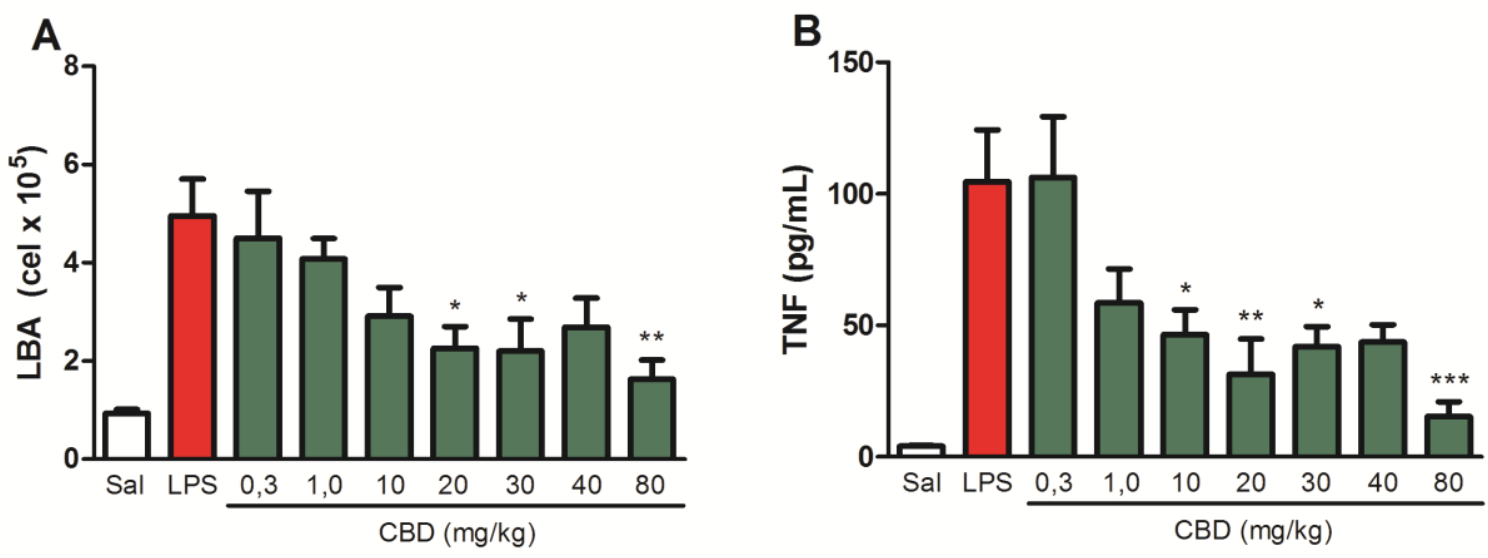

Figura 5 - Curva dose-resposta construída para avaliação dos efeitos do tratamento com CBD em um modelo murino de injúria pulmonar aguda (ALI). (A) contagem de leucócitos totais no LBA e (B) concentração de TNF no LBA. ${ }^{*} p<0,05,{ }^{* *} p<0,001 e^{* * *} p<0,0001$ quando comparados ao grupo veículo+LPS. ANOVA de uma via seguido do teste de Tukey-Kramer de comparações múltiplas, $n=4-5$ animais/grupo 
5.1.2 O tratamento com CBD diminui prolongadamente a migração de leucócitos para os pulmões

Baseados nos resultados anteriores, decidimos utilizar o CBD na dose de 20 $\mathrm{mg} / \mathrm{kg}$ nos experimentos subsequentes. Escolhemos esta dose pois foi a menor entre as avaliadas a diminuir a migração de leucócitos para o pulmão e a produção de TNF no LBA. Decidimos, então, analisar de forma mais aprofundada a migração de leucócitos para o pulmão. Quantificamos a presença de neutrófilos, macrófagos/monócitos e linfócitos no LBA dos animais submetidos à inflamação pulmonar ao longo do tempo. Assim, investigamos os efeitos do CBD $20 \mathrm{mg} / \mathrm{kg}$ na migração de leucócitos para os pulmões, 1, 2, 4 e 7 dias após a indução da inflamação pulmonar. Para tanto, setenta e sete camundongos foram separados ao acaso em 3 grupos (veículo+sal, veículo+LPS, CBD 20+LPS) e avaliados 1, 2, 4 e 7 dias após a indução da inflamação. Brevemente, os animais receberam uma dose de CBD ou veículo (i.p.), 60 min após foram anestesiados e receberam solução salina ou LPS por via intra-nasal. Veja a representação esquemática abaixo, figura 6.

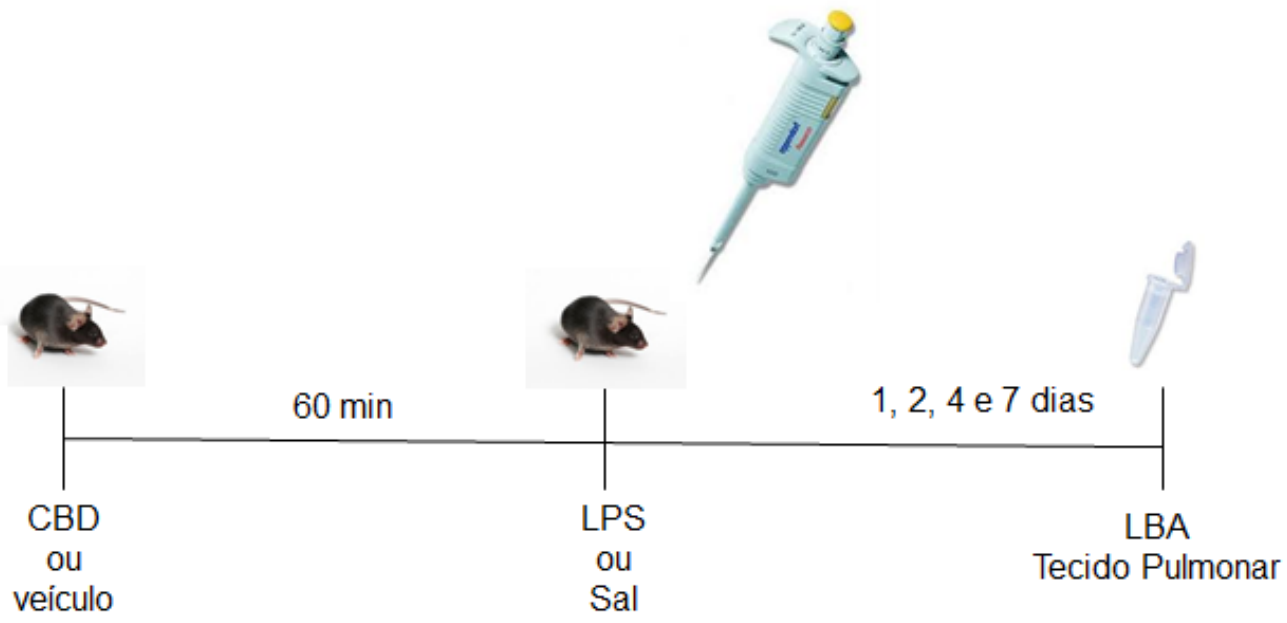

Figura 6 - Representação esquemática do protocolo experimental profilático de tratamento e indução da inflamação pulmonar 


\section{RESULTADOS:}

A tabela 2 mostra os efeitos do tratamento com CBD $20 \mathrm{mg} / \mathrm{kg}$ na migração de leucócitos totais para os pulmões de animais submetidos ao modelo de ALI. Observa-se que a instilação intra-nasal com LPS aumenta de forma significativa a contagem total de leucócitos no LBA nos animais do grupo controle inflamado (veículo+LPS), $1(F(2,15)=27,4 ; p<0,0001), 2(F(2,16)=38,6 ; p<0,0001)$ e $4(F$ $(2,17)=17,3 ; p<0,0001$ ) dias após a indução da inflamação pulmonar (Figura 7). Observamos, ainda, que o tratamento com o CBD diminuiu a contagem de leucócitos, $1(F(2,15)=27,4 ; p<0,0001), 2(F(2,16)=38,6 ; p<0,0001)$ e $4(F$ $(2,17)=17,3 ; p<0,001)$ dias após a indução da inflamação pulmonar (Figura 7). Após 7 dias, não observamos nenhuma mudança $(F(2,17)=2,3 ; p>0,05)$, pois a inflamação pulmonar já havia sido quase que completamente resolvida (Figura 7).

Tabela 2 - Efeitos do CBD sobre a migração de leucócitos para os pulmões de camundongos submetidos ao modelo de ALI

LBA ( $\mathrm{n}^{\circ}$ de células $\times 10^{5}$ )

\begin{tabular}{c|cccc}
\cline { 2 - 5 } Grupos & $\mathbf{1}$ dia & 2 dias & 4 dias & $\mathbf{7 d i a s}$ \\
\hline Veículo + Sal & $0,5 \pm 0,1$ & $0,8 \pm 0,1$ & $0,7 \pm 0,1$ & $0,8 \pm 0,1$ \\
\hline Veículo + LPS & $4,6 \pm 0,6 \boldsymbol{a}$ & $8,8 \pm 0,6 \boldsymbol{a}$ & $2,5 \pm 0,3 \boldsymbol{a}$ & $1,5 \pm 0,3$ \\
\hline CBD 20 + LPS & $2,1 \pm 0,2 \boldsymbol{b}$ & $5,0 \pm 0,8 \boldsymbol{b}$ & $1,2 \pm 0,2 \boldsymbol{b}$ & $1,0 \pm 0,1$ \\
\hline
\end{tabular}

Os dados representam a média \pm erro padrão, correspondente à contagem total de leucócitos no LBA. A letra a representa um $p<0,05$ quando comparado ao grupo veículo+sal e a letra $\boldsymbol{b}$ representa um $\mathrm{p}<0,05$ quando comparado ao grupo veículo+LPS. Foi utilizado o teste estatístico ANOVA de uma via seguido do teste de Tukey-Kramer de comparações múltiplas, $\mathrm{n}=4-9$ animais/grupo. 


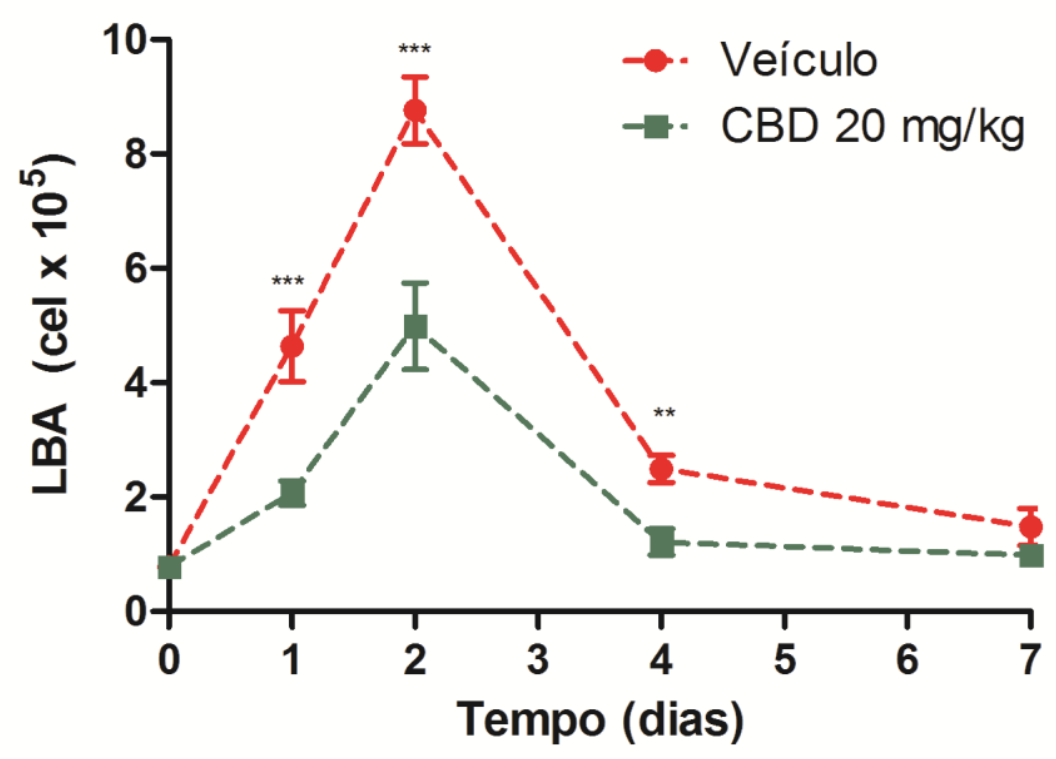

Figura 7 - Efeitos do CBD sobre a migração de leucócitos para os pulmões de camundongos submetidos ao modelo murino de ALI, 1, 2, 4 e 7 dias após a indução da inflamação. ${ }^{* *} p<0,001 e^{* * *} p<0,0001$ quando comparados ao grupo veículo+LPS. ANOVA de uma via seguido do teste de Tukey-Kramer de comparações múltiplas, $n=4-9$ animais/grupo

Analisamos, também, a contagem diferencial de leucócitos no LBA. A tabela 3 mostra que o CBD diminuiu a migração de neutrófilos $(F(2,15)=16,6, p<0,001$ (1 dia); $F(2,16)=14,6, p<0,001$ (2 dias); $F(2,16)=6,0, p<0,05$ (4 dias)), linfócitos ( $F$ $(2,15)=17,7, \mathrm{p}<0,0001$ (1 dia); $\mathrm{F}(2,16)=36,1, \mathrm{p}<0,0001$ (2 dias); $\mathrm{F}(2,16)=7,0$, $\mathrm{p}<0,05$ (4 dias)) e macrófagos $(\mathrm{F}(2,15)=19,4, \mathrm{p}<0,001$ (1 dia); $\mathrm{F}(2,16)=16,1, \mathrm{p}$ $<0,05$ (2 dias); $\mathrm{F}(2,16)=14,5, \mathrm{p}<0,001$ (4 dias)) para os pulmões, 1, 2 e 4 dias após a indução da inflamação. Observamos, ainda, que 7 dias da indução da ALI permanecia uma pequena presença de neutrófilos nos pulmões dos animais do grupo inflamado (veiculo+LPS) e que o tratamento com CBD aboliu completamente a presença destas células $(F(2,17)=5,5 ; p<0,05)$. 
Tabela 3 - Efeitos do CBD sobre a contagem diferencial de leucócitos no LBA de camundongos submetidos ao modelo de ALI

\section{Contagem diferencial de Leucócitos no LBA}

\begin{tabular}{|c|c|c|c|c|c|}
\hline $\begin{array}{l}\text { Tipo } \\
\text { celular }\end{array}$ & Grupos & 1 dia & 2 dias & 4 dias & 7 dias \\
\hline \multirow{3}{*}{ 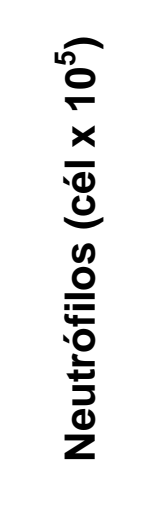 } & $\begin{array}{c}\text { Veículo + } \\
\text { Sal }\end{array}$ & $0,03 \pm 0,01$ & $0,2 \pm 0,1$ & $0,04 \pm 0,01$ & $0,03 \pm 0,01$ \\
\hline & $\begin{array}{c}\text { Veículo + } \\
\text { LPS }\end{array}$ & $1,1 \pm 0,2 \mathbf{a}$ & $3,2 \pm 0,5 a$ & $0,1 \pm 0,01 \mathbf{a}$ & $0,2 \pm 0,1 a$ \\
\hline & $\begin{array}{c}\text { CBD } 20+ \\
\text { LPS }\end{array}$ & $0,4 \pm 0,03 \boldsymbol{b}$ & $1,4 \pm 0,3 \boldsymbol{b}$ & $0,05 \pm 0,01 \boldsymbol{b}$ & $0,1 \pm 0,01 \boldsymbol{b}$ \\
\hline \multirow{3}{*}{ 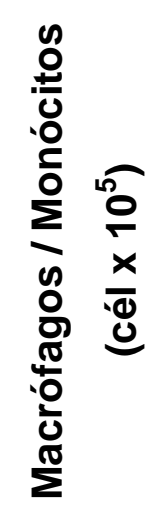 } & $\begin{array}{c}\text { Veículo + } \\
\text { Sal }\end{array}$ & $0,4 \pm 0,04$ & $0,4 \pm 0,1$ & $0,5 \pm 0,1$ & $0,9 \pm 0,2$ \\
\hline & $\begin{array}{c}\text { Veículo + } \\
\text { LPS }\end{array}$ & $2,8 \pm 0,4 \boldsymbol{a}$ & $3,8 \pm 0,3 \boldsymbol{a}$ & $1,9 \pm 0,2 \boldsymbol{a}$ & $1,0 \pm 0,2$ \\
\hline & $\begin{array}{c}\text { CBD } 20+ \\
\text { LPS }\end{array}$ & $1,5 \pm 0,2 \boldsymbol{b}$ & $2,2 \pm 0,5 \boldsymbol{b}$ & $1,0 \pm 0,2 \boldsymbol{b}$ & $0,7 \pm 0,1$ \\
\hline \multirow{3}{*}{ 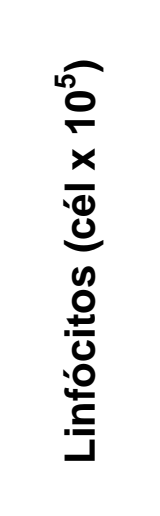 } & $\begin{array}{c}\text { Veículo + } \\
\text { Sal }\end{array}$ & $0,1 \pm 0,03$ & $0,2 \pm 0,04$ & $0,1 \pm 0,01$ & $0,1 \pm 0,01$ \\
\hline & $\begin{array}{c}\text { Veículo + } \\
\text { LPS }\end{array}$ & $0,7 \pm 0,1 \boldsymbol{a}$ & $1,5 \pm 0,2 \boldsymbol{a}$ & $0,2 \pm 0,03 \mathbf{a}$ & $0,3 \pm 0,1 \boldsymbol{a}$ \\
\hline & $\begin{array}{c}\text { CBD } 20+ \\
\text { LPS }\end{array}$ & $0,2 \pm 0,03 \boldsymbol{b}$ & $0,4 \pm 0,1 \boldsymbol{b}$ & $0,1 \pm 0,02 \boldsymbol{b}$ & $0,1 \pm 0,01$ \\
\hline
\end{tabular}

Os dados representam a média \pm erro padrão, correspondente à contagem diferencial de leucócitos no LBA. A letra a representa um $p<0,05$ quando comparado ao grupo veículo+sal e a letra $\boldsymbol{b}$ representa um $\mathrm{p}<0,05$ quando comparado ao grupo veículo+LPS. Foi utilizado o teste estatístico ANOVA de uma via seguido do teste de Tukey-Kramer de comparações múltiplas, $\mathrm{n}=4-9$ animais/grupo. 
5.1.3 O tratamento com CBD não altera a distribuição de leucócitos na medula óssea e no sangue

Analisamos os efeitos do CBD $20 \mathrm{mg} / \mathrm{kg}$ na distribuição de leucócitos no sangue e na medula óssea de camundongos submetidos ao modelo ALI. Assim, foram coletados a medula óssea e o sangue dos mesmos setenta e sete camundongos do experimento do item 5.1.2.

\section{RESULTADOS:}

A tabela 4 mostra que não foi observada nenhuma mudança significante entre os grupos, em nenhum dos períodos de tempo analisados, exceto por um aumento na contagem de células na medula óssea nos grupos veículo+LPS e CBD+LPS quando comparados com o grupo veículo+Sal $(F(2,17)=4,9 ; p<0,05)$, após 7 dias da indução da inflamação. 
Tabela 4 - Efeito do CBD sobre a distribuição de leucócitos na medula óssea e no sangue de camundongos submetidos ao modelo de ALI

\section{Distribuição de leucócitos}

\begin{tabular}{|c|c|c|c|c|c|}
\hline Compartimento & Grupos & 1 dia & 2 dias & 4 dias & 7 dias \\
\hline \multirow{3}{*}{ 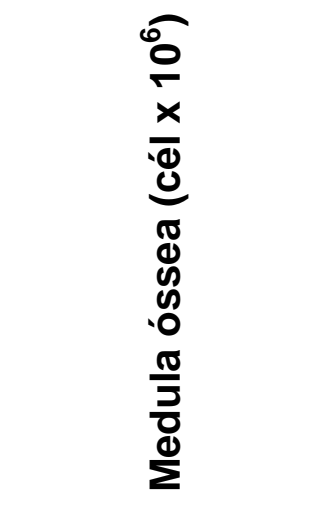 } & $\begin{array}{c}\text { Veículo + } \\
\text { Sal }\end{array}$ & $3.3 \pm 0.3$ & $2.8 \pm 0.5$ & $4.7 \pm 0.3$ & $3.3 \pm 0.3$ \\
\hline & $\begin{array}{c}\text { Veículo + } \\
\text { LPS }\end{array}$ & $2.9 \pm 0.2$ & $3.3 \pm 0.3$ & $4.7 \pm 0.4$ & $4.5 \pm 0.3 a$ \\
\hline & $\begin{array}{c}\text { CBD } 20+ \\
\text { LPS }\end{array}$ & $3.0 \pm 0.2$ & $2.8 \pm 0.4$ & $4.0 \pm 0.3$ & $4.4 \pm 0.2 a$ \\
\hline \multirow{3}{*}{ 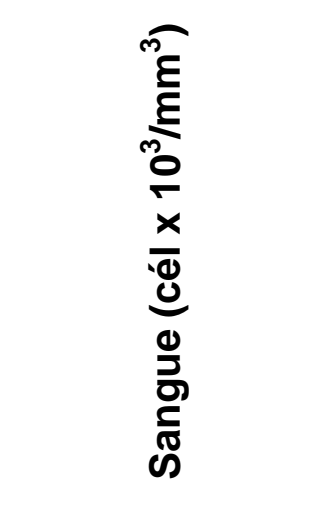 } & $\begin{array}{c}\text { Veículo + } \\
\text { Sal }\end{array}$ & $6.5 \pm 0.8$ & $7.7 \pm 1.0$ & $5.2 \pm 0.4$ & $4.9 \pm 0.3$ \\
\hline & $\begin{array}{l}\text { Veículo + } \\
\text { LPS }\end{array}$ & $7.9 \pm 0.8$ & $10.8 \pm 1.3$ & $6.2 \pm 0.4$ & $6.1 \pm 0.4$ \\
\hline & $\begin{array}{c}\text { CBD } 20+ \\
\text { LPS }\end{array}$ & $7.3 \pm 1.2$ & $9.3 \pm 1.5$ & $5.4 \pm 0.3$ & $6.1 \pm 0.5$ \\
\hline
\end{tabular}

Os dados representam a média \pm erro padrão, correspondente à contagem total de leucócitos na medula óssea e no sangue. A letra a representa um $p<0,05$ quando comparado ao grupo veículo+sal. Foi utilizado o teste estatístico ANOVA de uma via seguido do teste de Tukey-Kramer de comparações múltiplas, $n=4-9$ animais/grupo. 


\subsubsection{O CBD diminui a atividade de mieloperoxidase (MPO) no tecido pulmonar}

Devido à importância dos neutrófilos no modelo de $\mathrm{ALI}$, analisamos a atividade de MPO, uma medida indireta da atividade de neutrófilos no tecido pulmonar, 1, 2, 4 e 7 dias após a indução da ALI. Para tanto, setenta e cinco camundongos foram separados ao acaso em 3 grupos (veículo+sal, veículo+LPS, CBD 20+LPS) e avaliados 1, 2, 4 e 7 dias após a indução da inflamação. Brevemente, os animais receberam uma dose de CBD ou veículo (i.p.), $60 \mathrm{~min}$ após foram anestesiados e receberam solução salina ou LPS por via intra-nasal. Para efeito de análise estatística, os dados de atividade de MPO foram analisados utilizando o teste de Mann-Whitney $U$ após os valores terem sido normalizados como percentual do grupo controle não inflamado (veículo+Sal).

\section{RESULTADOS:}

A tabela 5 mostra que o CBD apresentou uma tendência em diminuir a atividade MPO, 1 dia $(U=6,0 ; p=0,06)$ após a indução da inflamação pulmonar. No entanto, observamos que o tratamento com o CBD diminuiu a atividade de MPO, 2 $(U=3,0 ; p<0,01)$ e $4(U=7,5 ; p<0,05)$ dias após a indução da inflamação. Após 7 dias não foi observado nenhuma diferença estatística entre os grupos, tampouco algum aumento da atividade de MPO quando comparado com o grupo não inflamado (veículo+Sal), provavelmente devido ao processo inflamatório estar praticamente resolvido (Figura 8). 
Tabela 5 - Efeito do CBD sobre a atividade de MPO no tecido pulmonar de camundongos submetidos ao modelo de ALI

Atividade de MPO (\% controle)

\begin{tabular}{c|cccc}
\hline Grupos & $\mathbf{1}$ dia & 2 dias & 4 dias & $\mathbf{7}$ dias \\
\hline Veículo + LPS & $224 \pm 17$ & $290 \pm 38$ & $139 \pm 7$ & $126 \pm 18$ \\
\hline CBD 20 + LPS & $165 \pm 16$ & $149 \pm 20 \boldsymbol{b}$ & $117 \pm 5 \boldsymbol{b}$ & $109 \pm 9$ \\
\hline
\end{tabular}

Os dados representam a média \pm erro padrão, correspondente a atividade de MPO no tecido pulmonar. A letra $\boldsymbol{b}$ representa um $\mathrm{p}<0,05$ quando comparado ao grupo veículo+LPS. Foi utilizado o teste estatístico Mann-Whitney U para comparação de dados não-paramétricos entre 2 grupos, $n=4-8$ animais/grupo.

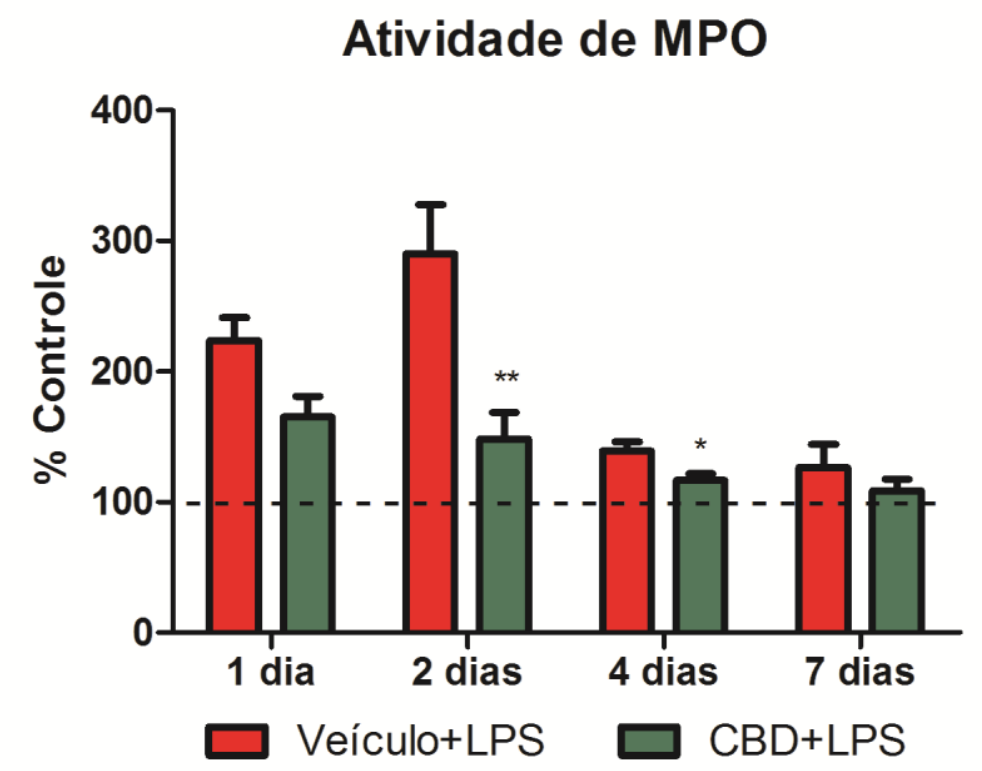

Figura 8 - Efeitos do CBD sobre a atividade de MPO no tecido pulmonar de camundongos submetidos ao modelo de ALI. * $p<0,05 e^{* *} p<0,001$ quando comparados ao grupo veículo+LPS. Teste de Mann-Whitney $U$ para comparação de dados não-paramétricos entre 2 grupos, $n=4-8$ animais/grupo 
5.1.5 $O C B D$ diminui a produção de citocinas e quimiocinas pró-inflamatórias no $\angle B A$

Na sequência investigamos a concentração de citocinas e quimiocinas próinflamatórias no LBA, 1, 2, 4 e 7 dias após a indução da inflamação. A análise de citocinas e quimiocinas no LBA nos pareceu importante para, primeiramente, caracterizar o nível da inflamação em cada time point analisado e, segundo, para tentar explicar a migração de leucócitos para os pulmões. Para tanto, 59 camundongos foram separados ao acaso em 3 grupos (veículo+sal, veículo+LPS, CBD 20+LPS) e avaliados 1, 2, 4 e 7 dias após a indução da inflamação. Brevemente, os animais receberam uma dose de CBD ou veículo (i.p.), 60 min após foram anestesiados e receberam solução salina ou LPS por via intra-nasal.

\section{RESULTADOS:}

A tabela 6 mostra que, 1 dia após a indução da inflamação, o CBD diminuiu a concentração de $\operatorname{TNF}(F(2,11)=15,7 ; p<0,01)$; no entanto, não foi observada qualquer alteração nos níveis de IL-12p70, IL-10, IL-6, e MCP-1, excetuando-se uma tendência de diminuição da produção de MIP-2 $(p=0,06)$. Dois dias após a indução da inflamação, observamos que o CBD diminuiu a concentração de $\operatorname{TNF}(F(2,12)=$ $5,5 ; p<0,05)$, IL-6 ( $F(2,12)=8,9 ; p<0,01)$, MCP-1 ( $(2,12)=14,3 ; p<0,0001)$, e MIP-2 (KW $=10,6 ; p<0,05)$; as outras citocinas analisadas (IL-12p70 e IL-10) permaneceram inalteradas nesse período de tempo. Finalmente, após 4 e 7 dias da indução da $\mathrm{ALI}$, nenhuma diferença foi encontrada nas citocinas/quimiocinas analisadas (Tabela 6 e Figura 9). A análise de IFN- $\gamma$ revelou níveis não detectáveis dessa citocina no LBA dos animais. 
Tabela 6 - Efeitos do CBD sobre a produção de citocina e quimiocinas no LBA de camundongos submetidos ao modelo de ALI

(Continua)

Produção de citocinas e quimiocinas no LBA

\begin{tabular}{|c|c|c|c|c|c|}
\hline $\begin{array}{l}\text { Citocinas e } \\
\text { Quimiocinas }\end{array}$ & Grupos & 1 dia & 2 dias & 4 dias & 7 dias \\
\hline \multirow{3}{*}{ 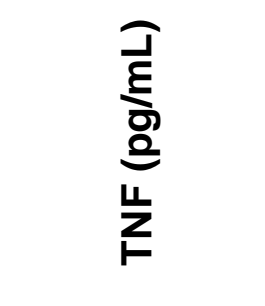 } & Veíc + Sal & $1,8 \pm 0,2$ & $9,2 \pm 3,8$ & $1,5 \pm 0,2$ & $1,4 \pm 0,1$ \\
\hline & Veíc + LPS & $60 \pm 7,1 a$ & $42 \pm 9,8 \boldsymbol{a}$ & $1,9 \pm 0,4$ & $4,9 \pm 2,6$ \\
\hline & CBD + LPS & $25 \pm 9,4 \boldsymbol{b}$ & $17 \pm 4,3 \boldsymbol{b}$ & $2,0 \pm 0,2$ & $2,8 \pm 0,4$ \\
\hline \multirow{3}{*}{ 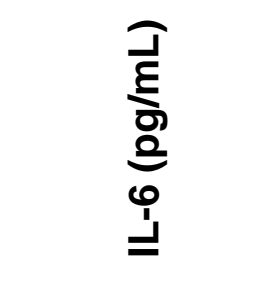 } & Veíc + Sal & $1,3 \pm 0,1$ & $0,5 \pm 0,1$ & $0,3 \pm 0,3$ & $0,8 \pm 0,3$ \\
\hline & Veíc + LPS & $25 \pm 8,7$ & $27 \pm 8,1 a$ & $1,0 \pm 0,3$ & $2,7 \pm 1,7$ \\
\hline & CBD + LPS & $16 \pm 5,2$ & $2,6 \pm 1,1 \boldsymbol{b}$ & $0,4 \pm 0,3$ & $1,5 \pm 0,2$ \\
\hline \multirow{3}{*}{ 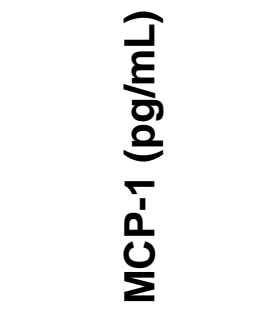 } & Veíc + Sal & $7,1 \pm 0,5$ & $20,5 \pm 3,9$ & $4,7 \pm 1,5$ & $6,0 \pm 0,7$ \\
\hline & Veíc + LPS & $22 \pm 2,1 \mathbf{a}$ & $71 \pm 11 a$ & $5,5 \pm 1,4$ & $6,4 \pm 2,6$ \\
\hline & CBD + LPS & $23 \pm 1,2 a$ & $29 \pm 1,7 \boldsymbol{b}$ & $6,5 \pm 1,1$ & $8,6 \pm 1,0$ \\
\hline \multirow{3}{*}{ 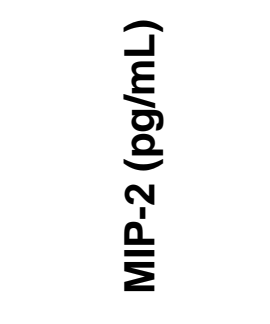 } & Veíc + Sal & $4,1 \pm 2,1$ & $4,1 \pm 2,1$ & $0,5 \pm 0,2$ & $0,5 \pm 0,2$ \\
\hline & Veíc + LPS & $72 \pm 9,8 a$ & $51 \pm 5,0 a$ & $1,1 \pm 0,5$ & $1,5 \pm 0,7$ \\
\hline & CBD + LPS & $50 \pm 14$ & $22 \pm 6,5 \boldsymbol{b}$ & $1,4 \pm 0,7$ & $1,5 \pm 0,3$ \\
\hline \multirow{3}{*}{ 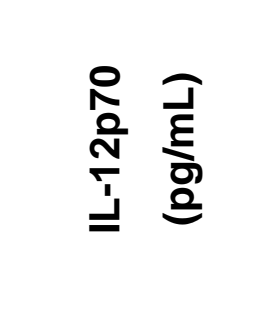 } & Veíc + Sal & $0,7 \pm 0,4$ & $4,9 \pm 1,1$ & $0,9 \pm 0,4$ & $0,7 \pm 0,4$ \\
\hline & Veíc + LPS & $1,7 \pm 0,9$ & $6,0 \pm 0,4$ & $1,2 \pm 0,5$ & $1,5 \pm 0,5$ \\
\hline & CBD + LPS & $1,7 \pm 0,2$ & $4,7 \pm 0,5$ & $1,2 \pm 0,5$ & $2,1 \pm 0,2$ \\
\hline
\end{tabular}


(Conclusão)

\begin{tabular}{|c|c|c|c|c|}
\hline Veíc + Sal & $1,7 \pm 1,0$ & $4,5 \pm 0,9$ & $1,1 \pm 0,7$ & $1,5 \pm 0,1$ \\
\hline Veíc + LPS & $3,8 \pm 0,5$ & $5,9 \pm 0,9$ & $2,2 \pm 1,5$ & $1,2 \pm 0,5$ \\
\hline CBD + LPS & $2,1 \pm 0,9$ & $4,9 \pm 0,8$ & $1,1 \pm 0,8$ & $3,2 \pm 0,9$ \\
\hline
\end{tabular}

Os dados representam a média \pm erro padrão, correspondente à concentração de citocinas e quimiocinas no LBA. A letra a representa um $p<0,05$ quando comparado ao grupo veículo+sal e a letra $\boldsymbol{b}$ representa um $p<0,05$ quando comparado ao grupo veículo+LPS. Foi utilizado o teste estatístico ANOVA de uma via seguido do teste de Tukey-Kramer de comparações múltiplas e o teste de Kruskal-Wallis seguido do teste de Dunn de comparações múltiplas, $n=4-7$ animais/grupo. 

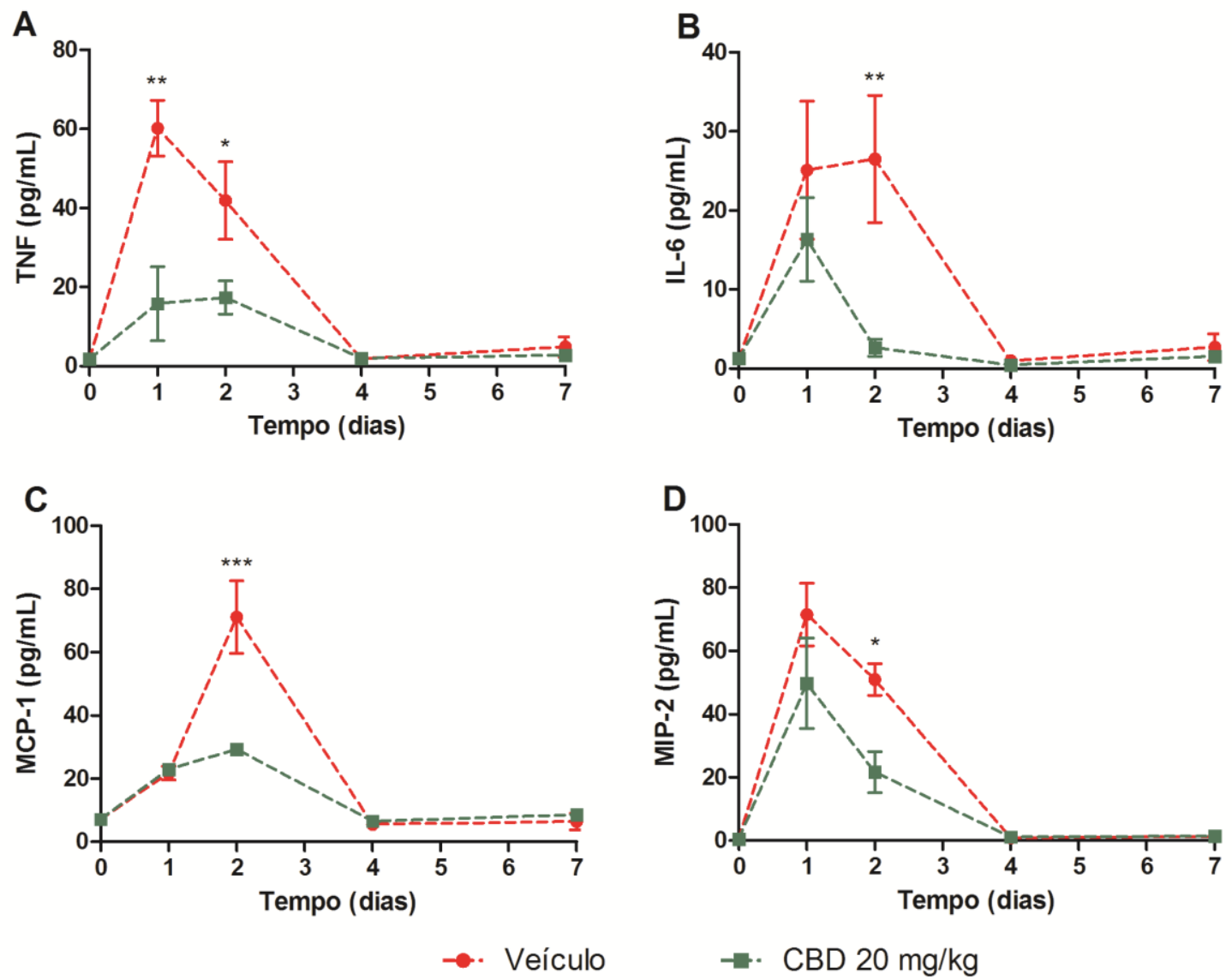

Figura 9 - Efeitos do CBD sobre a produção de citocinas e quimiocinas em camundongos submetidos ao modelo de ALI. (A) TNF, (B) IL-6, (C) MCP-1 e (D) MIP-2. * $p<0,05,{ }^{* *} p<0,001 e^{* * *} p<0,0001$ quando comparados ao grupo veículo+LPS. ANOVA de uma via seguido do teste de Tukey-Kramer de comparações múltiplas e teste de KruskalWallis seguido do teste de Dunn de comparações múltiplas, $n=4-7$ animais/grupo 
5.1.6 O CBD diminui a permeabilidade do endotélio vascular pulmonar

Investigamos a permeabilidade vascular pela medida indireta da presença de proteínas (albumina) no LBA, 1, 2, 4 e 7 dias após a indução da inflamação. Para tanto, 59 camundongos foram separados ao acaso em 3 grupos (veículo+sal, veículo+LPS, CBD 20+LPS) e avaliados 1, 2, 4 e 7 dias após a indução da inflamação. Brevemente, os animais receberam uma dose de CBD ou veículo (i.p.), 60 min após foram anestesiados e receberam solução salina ou LPS por via intranasal. Para efeito de análise estatística, os dados de concentração de proteínas no LBA foram analisados utilizando o teste de Mann-Whitney $U$ após os valores terem sido normalizados como percentual do grupo controle não inflamado (veículo+Sal).

\section{RESULTADOS:}

A tabela 7 mostra que o CBD diminuiu a concentração de proteínas no LBA, 1 $(U=5,5 ; p=0,05)$ e $2(U=7,0 ; p=0,05)$ dias após a indução da ALI. Após 4 e 7 dias nenhuma diferença estatisticamente significante foi encontrada na concentração de proteínas no LBA (Figura 10).

Tabela 7 - Efeitos do CBD sobre a concentração de albumina no LBA de camundongos submetidos ao modelo de ALI.

Proteína no LBA (\% controle)

\begin{tabular}{c|cccc}
\hline Grupos & $\mathbf{1}$ dia & $\mathbf{2}$ dias & $\mathbf{4}$ dias & $\mathbf{7}$ dias \\
\hline Veículo + LPS & $171 \pm 11$ & $145 \pm 10$ & $123 \pm 17$ & $110 \pm 5$ \\
\hline CBD 20 + LPS & $138 \pm 14 \boldsymbol{b}$ & $103 \pm 10 \boldsymbol{b}$ & $106 \pm 6$ & $112 \pm 7$ \\
\hline
\end{tabular}

Os dados representam a média \pm erro padrão, correspondente à concentração de albumina no LBA. A letra $\boldsymbol{b}$ representa um $\mathrm{p}<0,05$ quando comparado ao grupo veículo+LPS. Foi utilizado o teste estatístico Mann-Whitney U para comparação de dados não-paramétricos entre 2 grupos, $n=4-7$ animais/grupo. 


\section{Proteína no LBA}

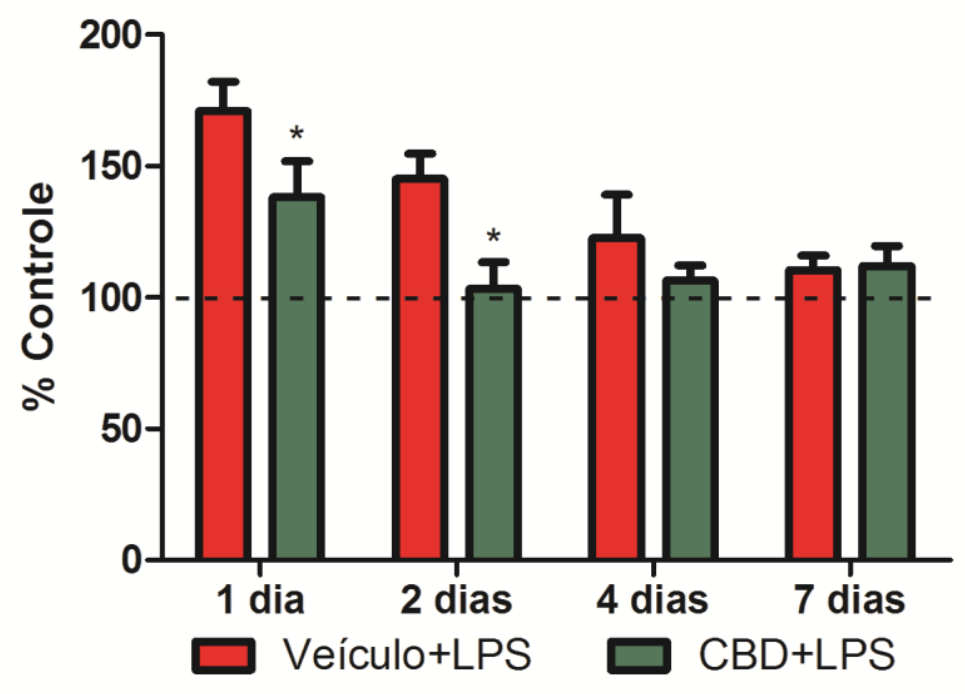

Figura 10 - Efeitos do CBD sobre a concentração de albumina no LBA de camundongos submetidos ao modelo de ALI. * $p<0,05$ quando comparados ao grupo veículo+LPS. Teste de Mann-Whitney U para comparação de dados não-paramétricos entre 2 grupos, $n=4-7$ animais/grupo 
5.1.7 $O$ antagonismo do receptor de adenosina A2A atenua os efeitos antiinflamatórios do CBD no modelo de ALI

O CBD é conhecido por exercer suas ações por diversos mecanismos de ação (ZUARDI, 2008). No entanto, o mecanismo que foi mostrado como sendo um dos principais responsáveis pelos efeitos anti-inflamatórios do CBD é a inibição competitiva de um transportador equilibrativo de adenosina, o que leva a um aumento de adenosina extracelular que, em consequência, leva a um aumento da sinalização via receptor de adenosina A2A. Foi mostrado que o bloqueio ou a depleção do gene do receptor de adenosina $A 2 A$ impediu que o CBD diminuisse a produção de TNF induzida pela administração sistêmica de LPS (CARRIER; AUCHAMPACH; HILLARD, 2006). Desta forma, resolvemos investigar o papel do receptor de adenosina $A 2 A$ nos efeitos anti-inflamatórios do $C B D$ relatados até aqui, utilizando o ZM241385, um antagonista altamente seletivo para o receptor de adenosina A2A. Para tanto, 102 camundongos foram separados ao acaso em 4 grupos (ZM+veículo+sal, ZM+veículo+LPS, ZM+CBD 20+LPS e veículo+ CBD 20+LPS) e avaliados 1, 2, 4 e 7 dias após a indução da inflamação. Brevemente, os animais receberam uma dose de ZM241385 (5 mg/kg, i.p.), após $30 \mathrm{~min}$ os animais receberam CBD ou veículo (i.p.), 60 min após foram anestesiados e receberam solução salina ou LPS por via intra-nasal. Veja a representação esquemática, figura 11.

Com este protocolo analisamos a migração de leucócitos totais para os pulmões, a atividade de MPO no tecido pulmonar, a produção de citocinas próinflamatórias no sobrenadante do LBA e a permeabilidade vascular pulmonar de animais submetidos ao modelo de ALI. 


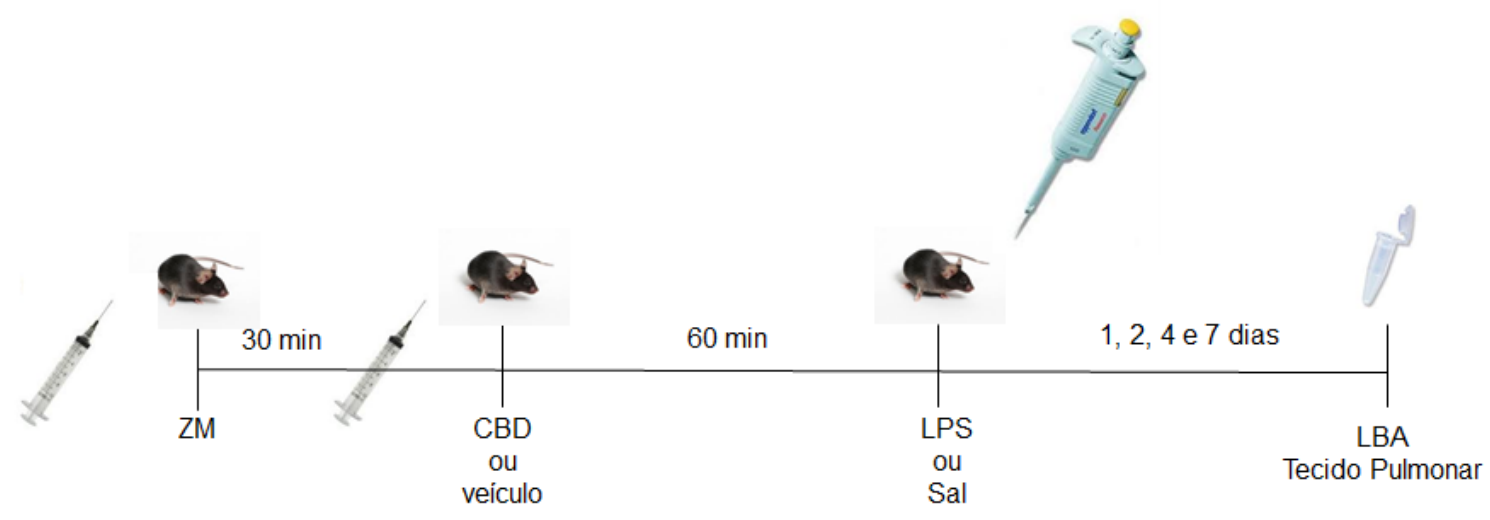

Figura 11 - Representação esquemática do protocolo experimental de tratamento e indução da inflamação pulmonar

\section{RESULTADOS:}

A tabela 8 mostra e a figura 12 ilustra os efeitos do pré-tratamento com ZM nos efeitos do CBD sobre a migração de leucócitos totais para os pulmões. Observamos que os animais tratados com CBD (veículo+CBD+LPS) apresentam uma diminuição da inflamação no dia $1(F(3,21)=3,7 ; p<0,05), 2(F(3,22)=9,5 ; p$ $<0,0001)$ e $4(F(3,21)=3,6 ; p<0,05)$ após a indução da inflamação. Observamos, ainda, que o tratamento com o ZM241385 preveniu a inibição da migração de leucócitos para os pulmões no dia 1, 2 e 4 após a indução da inflamação. Após 7 dias, não observamos qualquer mudança, pois a inflamação pulmonar já havia sido quase completamente resolvida. 
Tabela 8 - Efeito do antagonismo do receptor de adenosina A2A nos efeitos do CBD sobre a migração de leucócitos para os pulmões de camundongos submetidos ao modelo de ALI

LBA (células $\times 10^{5}$ )

\begin{tabular}{c|cccc}
\hline Grupos & $\mathbf{1}$ dia & 2 dias & $\mathbf{4}$ dias & $\mathbf{7}$ dias \\
\hline $\begin{array}{c}\text { ZM + Veículo + } \\
\text { Sal }\end{array}$ & $0,9 \pm 0,1$ & $0,7 \pm 0,1$ & $0,3 \pm 0,03$ & $0,7 \pm 0,2$ \\
$\begin{array}{c}\text { ZM + Veículo } \\
\text { + LPS }\end{array}$ & $5,5 \pm 1,0 \boldsymbol{a}$ & $10,7 \pm 1,9 \boldsymbol{a}$ & $2,0 \pm 0,5 \boldsymbol{a}$ & $1,3 \pm 0,2$ \\
$\begin{array}{c}\text { ZM + CBD 20 } \\
\text { + LPS }\end{array}$ & $5,7 \pm 1,5 \boldsymbol{a}$ & $9,7 \pm 1,5 \boldsymbol{a}$ & $2,5 \pm 0,5 \boldsymbol{a}$ & $1,1 \pm 0,1$ \\
$\begin{array}{c}\text { Veículo + } \\
\text { CBD 20 + LPS }\end{array}$ & $2,9 \pm 0,7 \boldsymbol{b}$ & $5,8 \pm 0,9 \boldsymbol{b}$ & $1,4 \pm 0,3 \boldsymbol{b}$ & $0,9 \pm 0,2$ \\
\hline
\end{tabular}

Os dados representam a média \pm erro padrão, correspondente à contagem de leucócitos totais no LBA. A letra a representa um $p<0,05$ quando comparado ao

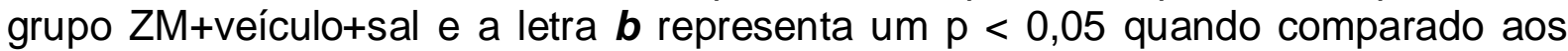
grupos ZM+veículo+LPS e ZM+CBD 20+LPS. Foi utilizado o teste estatístico ANOVA de uma via seguido do teste de Tukey-Kramer de comparações múltiplas, $n$ = 4-7 animais/grupo. 


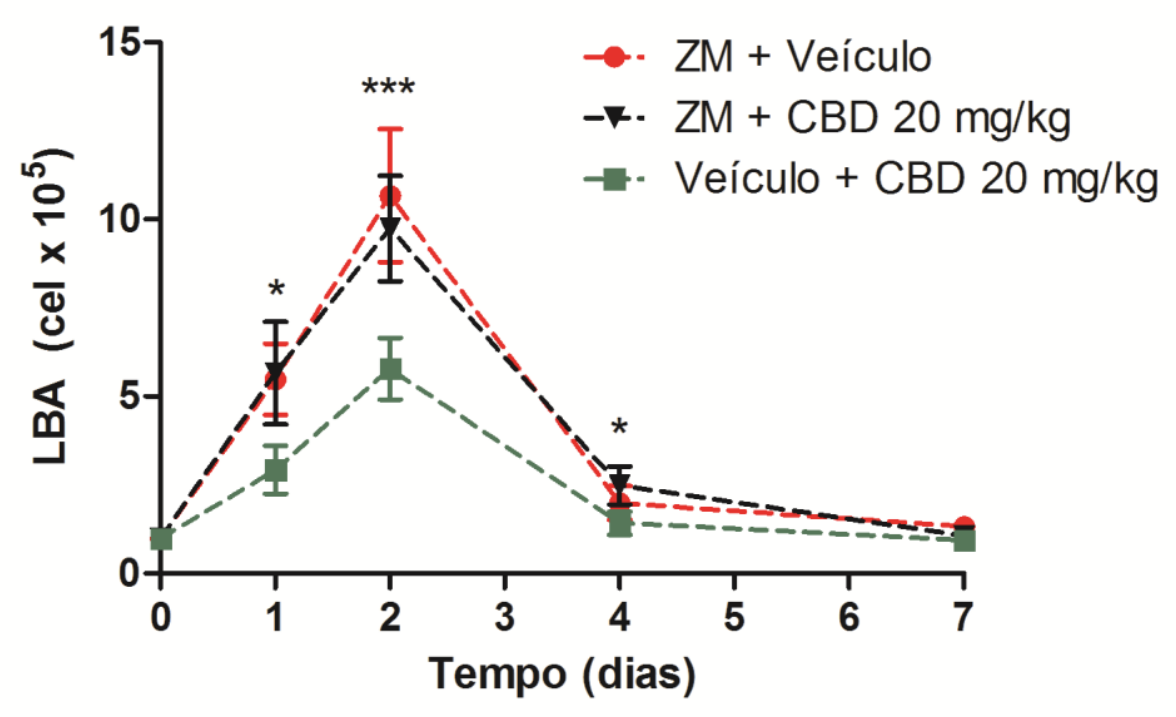

Figura 12 - Efeitos do antagonismo do receptor de adenosina A2A nos efeitos do CBD sobre a migração de células para os pulmões de camundongos submetidos ao modelo de ALI. * $p<0,05 e^{* * *} p<0,0001$ quando comparados ao grupo ZM+veículo+LPS e ZM+CBD 20+LPS. ANOVA de uma via seguido do teste de Tukey-Kramer de comparações múltiplas, $\mathrm{n}$ $=4-7$ animais/grupo

A tabela 9 mostra e a figura 13 ilustra os efeitos do pré-tratamento com ZM nos efeitos do CBD sobre a atividade de MPO no tecido pulmonar. Para efeito de análise estatística, os dados de atividade de MPO foram avaliados utilizando-se o teste de Kruskal-Wallis após os valores terem sido normalizados como percentual do grupo controle não inflamado (ZM+veículo+Sal). Observamos que os animais tratados com CBD (veículo+CBD+LPS) apresentaram uma diminuição da inflamação no dia 2 ( $K W=7,8 ; p<0,05)$ após a indução da inflamação. Observamos, ainda, que o tratamento com o ZM241385 preveniu a inibição da atividade de MPO no dia 2 após a indução da inflamação. Após 7 dias, não observamos qualquer mudança, pois a inflamação pulmonar já havia sido quase completamente resolvida. 
Tabela 9 - Efeito do antagonismo do receptor de adenosina A2A nos efeitos do CBD sobre a atividade de MPO no tecido pulmonar de camundongos submetidos ao modelo de ALI

Atividade de MPO (\% controle)

\begin{tabular}{c|cccc}
\hline $\begin{array}{c}\text { Grupos } \\
\text { ZM + Veículo } \\
\text { + LPS }\end{array}$ & $153 \pm 19$ & $249 \pm 26$ & $129 \pm 9$ & $102 \pm 13$ \\
$\begin{array}{c}\text { ZM + CBD 20 } \\
\text { + LPS }\end{array}$ & $149 \pm 13$ & $247 \pm 25$ & $114 \pm 5$ & $106 \pm 14$ \\
$\begin{array}{c}\text { Veículo + } \\
\text { CBD 20 + LPS }\end{array}$ & $121 \pm 11$ & $167 \pm 15 \boldsymbol{b}$ & $107 \pm 4$ & $108 \pm 10$ \\
\hline
\end{tabular}

Os dados representam a média \pm erro padrão, correspondente à atividade de MPO no tecido pulmonar. A letra $\boldsymbol{b}$ representa um $p<0,05$ quando comparado aos grupos ZM+veículo+LPS e ZM+CBD 20+LPS. Foi utilizado o teste estatístico Kruskal-Wallis seguido do teste de Dunn de comparações múltiplas, $n=5-9$ animais/grupo.

\section{Atividade de MPO}

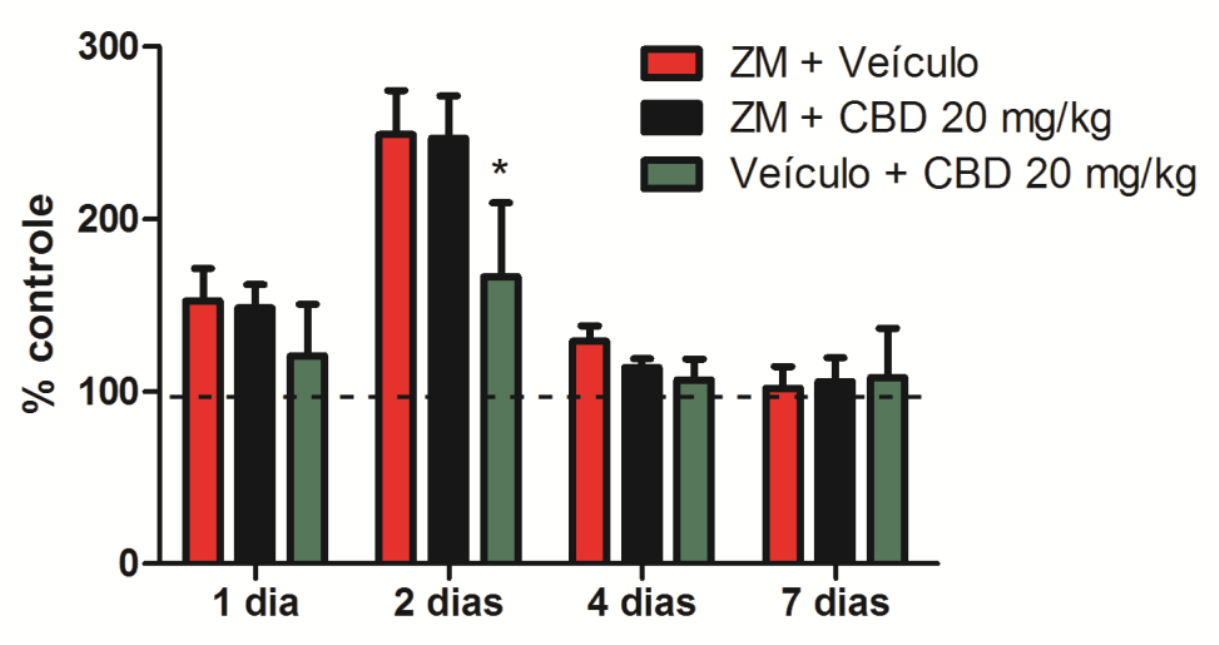

Figura 13 - Efeitos do antagonismo do receptor de adenosina A2A nos efeitos do CBD sobre a migração de células para os pulmões de camundongos submetidos ao modelo de ALI. * $p<0,05$ quando comparados ao grupo ZM+veículo+LPS e ZM+CBD 20+LPS. Kruskal-Wallis seguido do teste de Dunn de comparações múltiplas, $\mathrm{n}=5-9$ animais/grupo 
A tabela 10 mostra e a figura 14 ilustra os efeitos do pré-tratamento com ZM sobre os efeitos do $C B D$ na produção de citocinas e quimiocinas pró-inflamatórias no LBA. Observamos que o tratamento com o CBD (veículo+CBD+LPS) diminuiu a concentração de TNF $(F(3,19)=5,0 ; p<0,001)$, MCP-1 $(F(3,19)=3,7 ; p<0,05)$ e MIP-2 (KW = 11,9; $p<0,001)$ no LBA, 1 dia após a indução da inflamação. Ainda, 2 dias após a indução da inflamação, observou-se que o tratamento com o CBD diminuiu a concentração de TNF (KW = 14,6; $p<0,05)$, IL-6 (KW = 13,4; $p<0,001)$, MCP-1 (KW = 13,0; $p<0,001)$ e MIP-2 (KW = 12,1; $p<0,05)$ no LBA. Observamos que o pré-tratamento com o ZM241385 preveniu a diminuição da concentração de TNF, IL-6, MCP-1 e MIP-2 no LBA, 1 e 2 dias após a indução da inflamação pulmonar. Conforme relatado anteriormente, não se observou qualquer diferença estatisticamente significante nas concentrações de IL-12p70 e IL-10 no LBA entre os grupos nos dias 4 e 7 após a indução da inflamação. Além disso, concentrações de IFN- $\gamma$ não foram detectadas no LBA, conforme observado no item 5.1.5. 
Tabela 10 - Efeito do antagonismo do receptor de adenosina A2A nos efeitos do CBD sobre a concentração de citocinas e quimiocinas no LBA de camundongos submetidos ao modelo de ALI

(Continua)

Produção de citocinas e quimiocinas no LBA

\begin{tabular}{|c|c|c|c|c|c|}
\hline $\begin{array}{c}\text { Citocinas e } \\
\text { Quimiocinas }\end{array}$ & Grupos & 1 dia & 2 dias & 4 dias & 7 dias \\
\hline \multirow{4}{*}{ 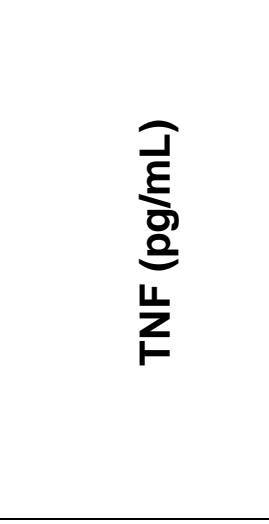 } & $\begin{array}{c}\text { ZM +Veíc + } \\
\text { Sal }\end{array}$ & $4,8 \pm 0,8$ & $2,1 \pm 0,4$ & $4,4 \pm 0,4$ & $5,7 \pm 0,3$ \\
\hline & $\begin{array}{l}\text { ZM + Veíc } \\
\text { + LPS }\end{array}$ & $81 \pm 10 a$ & $31 \pm 10 a$ & $5,6 \pm 0,9$ & $5,3 \pm 0,4$ \\
\hline & $\begin{array}{c}Z M+C B D \\
20+L P S\end{array}$ & $79 \pm 22 a$ & $25 \pm 5,4 a$ & $5,8 \pm 1,0$ & $3,9 \pm 0,6$ \\
\hline & $\begin{array}{c}\text { Veíc + CBD } \\
20 \text { + LPS }\end{array}$ & $33 \pm 10 b$ & $13 \pm 3,6 b$ & $4,5 \pm 0,6$ & $4,0 \pm 0,6$ \\
\hline \multirow{4}{*}{ 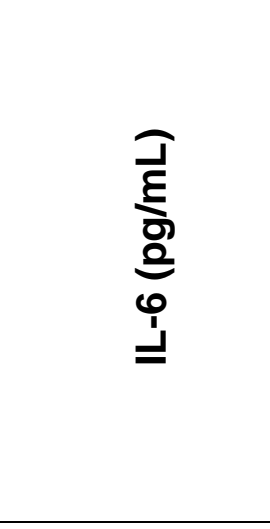 } & $\begin{array}{l}\text { ZM +Veíc + } \\
\text { Sal }\end{array}$ & $0,3 \pm 0,1$ & $0,3 \pm 0,2$ & $0,2 \pm 0,1$ & $0,3 \pm 0,02$ \\
\hline & $\begin{array}{l}\text { ZM + Veíc } \\
\text { + LPS }\end{array}$ & $13 \pm 4,5$ & $17 \pm 5,5 a$ & $0,3 \pm 0,04$ & $0,2 \pm 0,04$ \\
\hline & $\begin{array}{c}Z M+C B D \\
20+\text { LPS }\end{array}$ & $10 \pm 3,1$ & $14 \pm 4,7 a$ & $0,3 \pm 0,1$ & $0,2 \pm 0,03$ \\
\hline & $\begin{array}{c}\text { Veíc + CBD } \\
20+\text { LPS }\end{array}$ & $7,4 \pm 2,5$ & $9,0 \pm 4,1 b$ & $0,3 \pm 0,1$ & $0,2 \pm 0,04$ \\
\hline \multirow{4}{*}{ 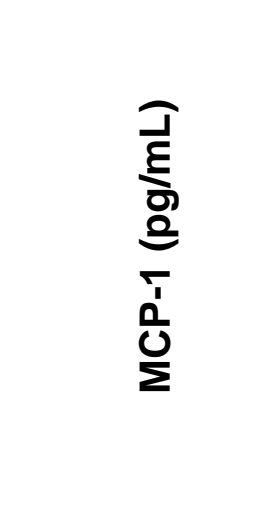 } & $\begin{array}{c}\text { ZM +Veíc + } \\
\text { Sal }\end{array}$ & $10,6 \pm 1,5$ & $5,8 \pm 1,5$ & $14 \pm 2,6$ & $20 \pm 2,0$ \\
\hline & $\begin{array}{l}\text { ZM + Veíc } \\
\text { + LPS }\end{array}$ & $22 \pm 2,9 a$ & $46 \pm 10 a$ & $16 \pm 3,0$ & $20 \pm 2,3$ \\
\hline & $\begin{array}{c}Z M+C B D \\
20+\text { LPS }\end{array}$ & $19 \pm 1,1 a$ & $40 \pm 9 a$ & $19 \pm 2,7$ & $15 \pm 2,5$ \\
\hline & $\begin{array}{c}\text { Veíc + CBD } \\
20 \text { + LPS }\end{array}$ & $14 \pm 2,6$ & $25 \pm 6,6 \boldsymbol{b}$ & $14 \pm 2,4$ & $16 \pm 2,1$ \\
\hline
\end{tabular}


(Conclusão)

\begin{tabular}{|c|c|c|c|c|c|}
\hline $\begin{array}{c}\text { Citocinas e } \\
\text { Quimiocinas }\end{array}$ & Grupos & $1 \mathrm{dia}$ & 2 dias & 4 dias & 7 dias \\
\hline \multirow{4}{*}{ 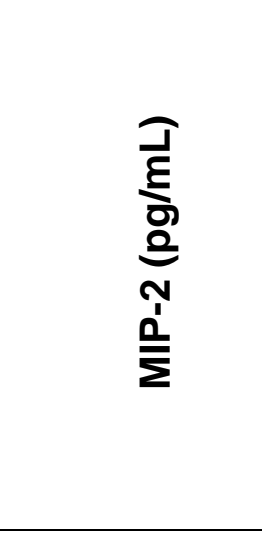 } & $\begin{array}{c}\text { ZM + Veíc + } \\
\text { Sal }\end{array}$ & $1,5 \pm 0,9$ & $0,4 \pm 0,4$ & $0,1 \pm 0,1$ & $1,4 \pm 0,2$ \\
\hline & $\begin{array}{c}\text { ZM + Veíc } \\
\text { + LPS }\end{array}$ & $107 \pm 16 a$ & $31 \pm 6,7 \mathbf{a}$ & $1,4 \pm 0,7$ & $2,0 \pm 0,1$ \\
\hline & $\begin{array}{c}Z M+C B D \\
20+L P S\end{array}$ & $93 \pm 22 a$ & $25 \pm 3,7 a$ & $1,5 \pm 0,4$ & $1,2 \pm 0,3$ \\
\hline & $\begin{array}{c}\text { Veíc + CBD } \\
20 \text { + LPS }\end{array}$ & $50 \pm 12 b$ & $14 \pm 2,3 \boldsymbol{b}$ & $1,7 \pm 0,9$ & $2,0 \pm 0,6$ \\
\hline \multirow{4}{*}{ 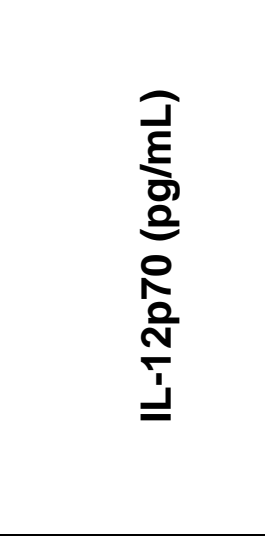 } & $\begin{array}{c}\text { ZM +Veíc + } \\
\text { Sal }\end{array}$ & $4,0 \pm 0,6$ & $0,4 \pm 0,4$ & $3,2 \pm 0,4$ & $4,0 \pm 0,4$ \\
\hline & $\begin{array}{c}\text { ZM + Veíc } \\
\text { + LPS }\end{array}$ & $4,6 \pm 0,4$ & $1,1 \pm 0,4$ & $3,7 \pm 1,1$ & $3,1 \pm 0,5$ \\
\hline & $\begin{array}{c}Z M+C B D \\
20 \text { + LPS }\end{array}$ & $3,8 \pm 0,6$ & $0,8 \pm 0,5$ & $3,2 \pm 0,5$ & $2,1 \pm 0,2$ \\
\hline & $\begin{array}{c}\text { Veíc + CBD } \\
20 \text { + LPS }\end{array}$ & $3,3 \pm 1,0$ & $1,5 \pm 0,4$ & $3,2 \pm 0,6$ & $2,4 \pm 0,4$ \\
\hline \multirow{4}{*}{ 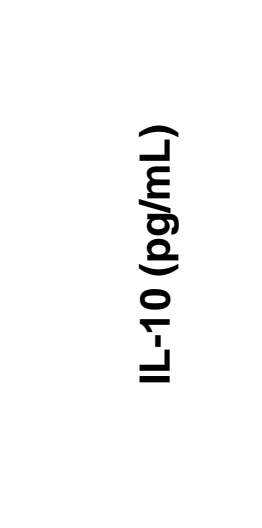 } & $\begin{array}{c}\text { ZM + Veíc + } \\
\text { Sal }\end{array}$ & $2,5 \pm 1,2$ & $2,3 \pm 0,4$ & $2,0 \pm 0,3$ & $2,3 \pm 0,5$ \\
\hline & $\begin{array}{c}\text { ZM + Veíc } \\
\text { + LPS }\end{array}$ & $3,5 \pm 0,5$ & $2,0 \pm 0,7$ & $3,5 \pm 1,1$ & $2,7 \pm 0,8$ \\
\hline & $\begin{array}{c}Z M+C B D \\
20+L P S\end{array}$ & $3,0 \pm 0,7$ & $2,9 \pm 0,3$ & $2,0 \pm 0,5$ & $1,3 \pm 0,4$ \\
\hline & $\begin{array}{c}\text { Veíc + CBD } \\
20+\text { LPS }\end{array}$ & $2,7 \pm 0,6$ & $2,9 \pm 0,6$ & $2,7 \pm 0,4$ & $2,4 \pm 0,7$ \\
\hline
\end{tabular}

Os dados representam a média \pm erro padrão, correspondente à concentração de citocinas e quimiocinas no LBA. A letra a representa um $p<0,05$ quando comparado

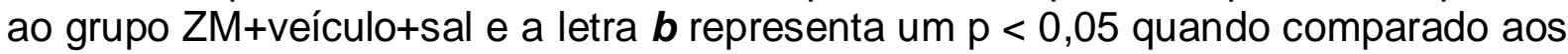
grupos ZM+veículo+LPS e ZM+CBD 20+LPS. Foi utilizado o teste estatístico ANOVA de uma via seguido do teste de Tukey-Kramer de comparações múltiplas e o teste Kruskal-Wallis seguido do teste de Dunn de comparações múltiplas, $n=4-8$ animais/grupo. 

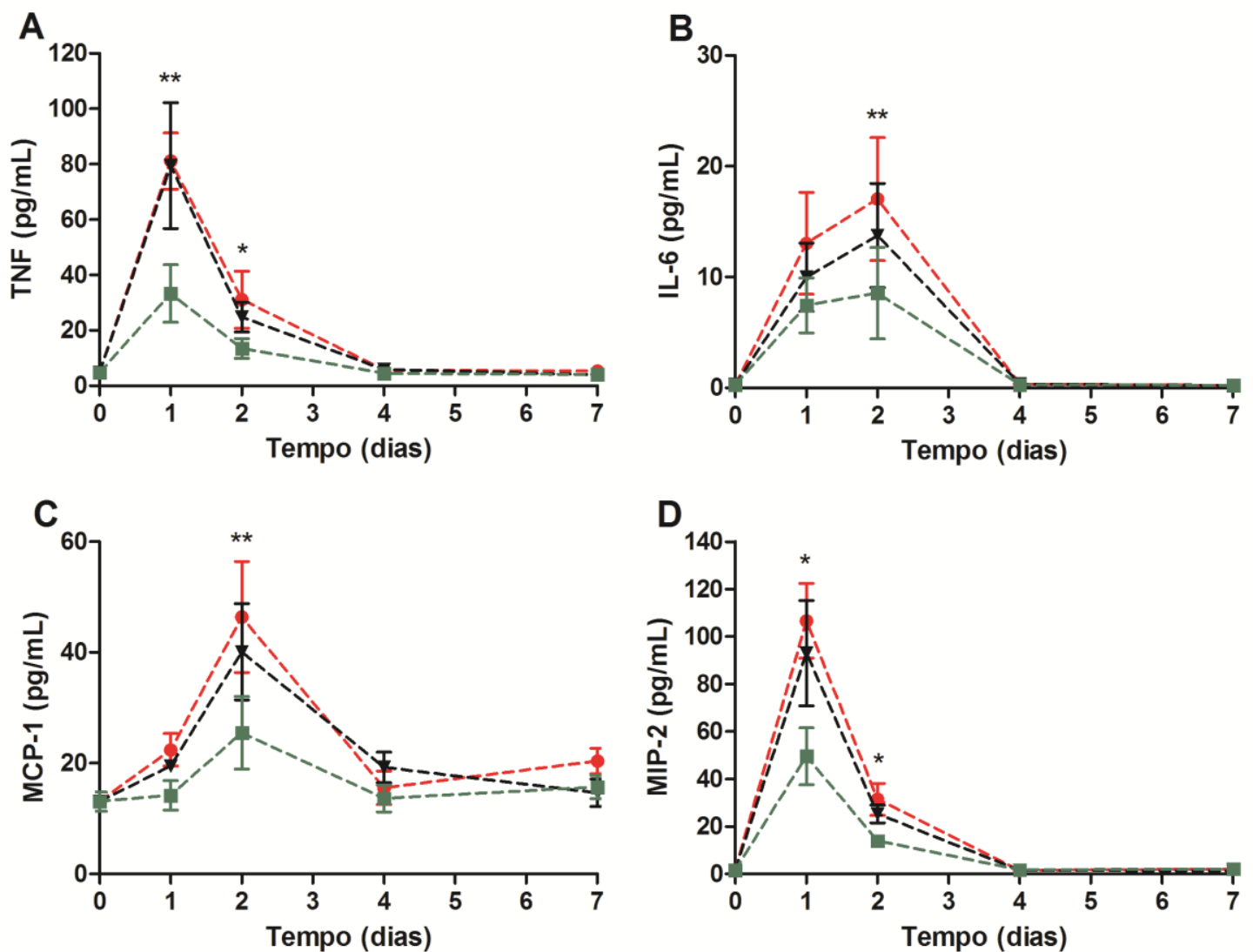

$\rightarrow$ ZM + Veículo $\quad$-r. ZM + CBD 20 mg/kg $\quad \rightarrow$ - Veículo + CBD 20 mg/kg

Figura 14 - Efeitos do antagonismo do receptor de adenosina A2A nos efeitos do CBD sobre a concentração de citocinas e quimiocinas no LBA de camundongos submetidos ao modelo de ALI. (A) TNF, (B) IL-6, (C) MCP-1 e (D) MIP-2. * $p<0,05 e^{* *} p<0,001$ quando comparados ao grupo ZM+veículo+LPS e ZM+CBD 20+LPS. ANOVA de uma via seguido do teste de Tukey-Kramer de comparações múltiplas e KruskalWallis seguido do teste de Dunn de comparações múltiplas, $n=4-8$ animais/grupo

A tabela 11 mostra e a figura 15 ilustra os efeitos do pré-tratamento com ZM nos efeitos do CBD sobre a permeabilidade vascular nos pulmões. Observamos que o tratamento com o CBD (veículo+CBD+LPS) diminuiu a concentração de proteínas no LBA, $2(\mathrm{KW}=4,9 ; \mathrm{p}<$ 0,05) e $4(\mathrm{KW}=9,7 ; \mathrm{p}<0,001)$ dias após a indução da inflamação. Observamos, ainda, que o pré-tratamento com o ZM241385 preveniu a diminuição da concentração de proteínas no LBA, 1,2 e 4 após a indução da inflamação. Após 7 dias, não observamos qualquer mudança, pois a inflamação pulmonar já havia sido quase completamente resolvida. 
Tabela 11 - Efeito do antagonismo do receptor de adenosina A2A nos efeitos do CBD sobre a atividade de MPO no tecido pulmonar de camundongos submetidos ao modelo de ALI

Proteína no LBA (\% controle)

\begin{tabular}{c|cccc}
\hline Grupos & $\mathbf{1}$ dia & 2 dias & $\mathbf{4}$ dias & $\mathbf{7}$ dias \\
\hline $\begin{array}{c}\text { ZM + Veículo } \\
\text { + LPS }\end{array}$ & $158 \pm 15$ & $150 \pm 21$ & $127 \pm 7$ & $102 \pm 5$ \\
$\begin{array}{c}\text { ZM + CBD 20 } \\
\text { + LPS }\end{array}$ & $165 \pm 21$ & $154 \pm 17$ & $117 \pm 3$ & $106 \pm 4$ \\
$\begin{array}{c}\text { Veículo + } \\
\text { CBD 20 + LPS }\end{array}$ & $127 \pm 11$ & $108 \pm 7 \boldsymbol{b}$ & $101 \pm 4 \boldsymbol{b}$ & $106 \pm 7$ \\
\hline
\end{tabular}

Os dados representam a média \pm erro padrão, correspondente à concentração de albumina no LBA. A letra $\boldsymbol{b}$ representa um $p<0,05$ quando comparado aos grupos ZM+veículo+LPS e ZM+CBD 20+LPS. Foi utilizado o teste estatístico Kruskal-Wallis seguido do teste de Dunn de comparações múltiplas, $n=4-8$ animais/grupo.

\section{Proteína no LBA}

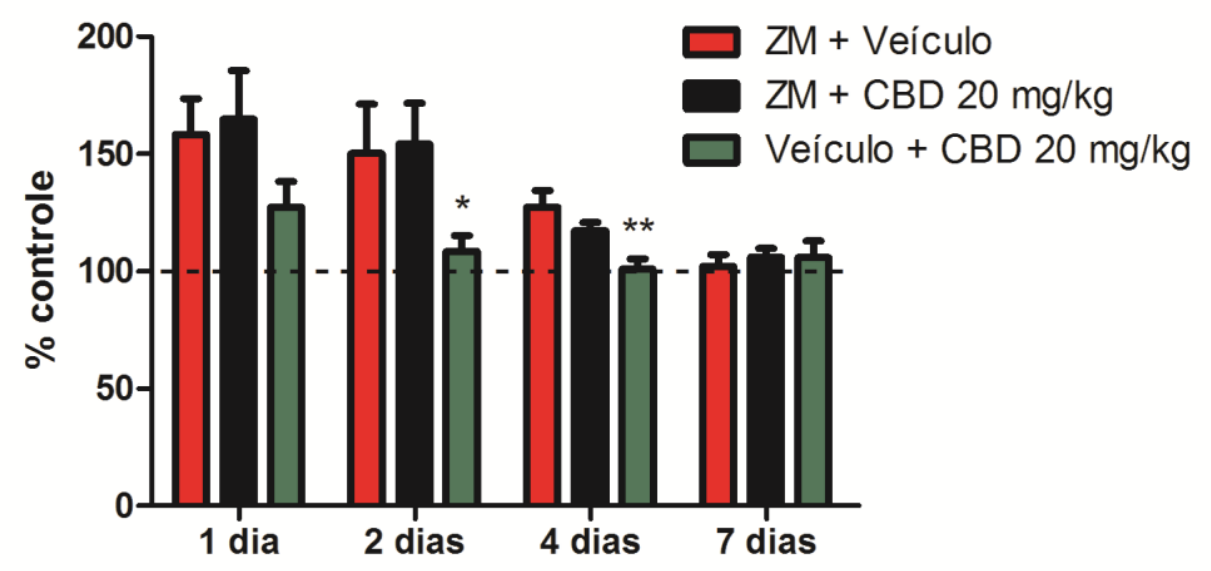

Figura 15 - Efeitos do antagonismo do receptor de adenosina A2A nos efeitos do CBD sobre a migração de células para os pulmões de camundongos submetidos ao modelo de ALI. * $p<0,05$ e ** $p<0,001$ quando comparados ao grupo ZM+veículo+LPS e ZM+CBD 20+LPS. KruskalWallis seguido do teste de Dunn de comparações múltiplas, $n=4-8$ animais/grupo 
Desta forma, demonstramos, com estes experimentos (item 5.1.7.), que o uso de um antagonista do receptor de adenosina A2A preveniu os efeitos antiinflamatórios do CBD em animais submetidos ao modelo de ALI. 
5.1.8 O CBD altera a percentagem de células $T$ regulatórias (CD4+FoxP3+) no $\angle B A$, no sangue e no baço

Após a análise dos efeitos do CBD em diversos parâmetros da inflamação, pensamos que seria interessante avaliar um aspecto importante da imunidade adquirida. Dados relativamente recentes de literatura apontam para um papel das células T regulatórias (Treg) na resolução do modelo de ALI induzido por LPS (D’Alessio et al,, 2009). Desta forma, avaliamos a distribuição de células Treg no LBA, no sangue e no baço, 1 e 2 dias após a indução da ALI. Para tanto, 40 camundongos C57BL/6 FoxP3-GFP knockin foram separados ao acaso em 3 grupos (veículo+sal, veículo+LPS, CBD 20+LPS) e avaliados 1 e 2 dias após a indução da inflamação. Brevemente, os animais receberam uma dose de CBD ou veículo (i.p.); 60 min após, foram anestesiados e receberam solução salina ou LPS por via intranasal.

\section{RESULTADOS:}

A tabela 12 mostra os efeitos do tratamento com CBD na distribuição de células Treg no LBA, no sangue e no baço. Observamos que os animais tratados com CBD apresentaram um aumento no percentual de células Treg no baço ( $F$ $(2,20)=22,6 ; p<0,0001)$ e uma diminuição das mesmas no sangue $(F(2,20)=$ 24,$1 ; p<0,0001$ ), após 1 dia após a indução da inflamação (Figura 16). Não se observou qualquer diferença estatística no percentual de células Treg no LBA. Após 2 dias da indução da inflamação, observamos que o tratamento com o CBD aumentou o percentual de células Treg no sangue $(F(2,16)=21,4 ; p<0,001)$. Não se observou qualquer diferença estatística no percentual de células Treg quer no baço ou no LBA (Figura 17). 
Tabela 12 - Efeitos do CBD sobre o percentual de células Treg no LBA, no sangue e no baço de camundongos submetidos ao modelo de ALI

Células T regulatórias (CD4+FoxP3+)

\begin{tabular}{c|c|cc}
\hline Compartimento & Grupos & $\mathbf{1 ~ d i a}$ & 2 dias \\
\hline \multirow{2}{*}{ LBA (\%) } & Veículo + Sal & $0,5 \pm 0,02$ & $1,2 \pm 0,4$ \\
\cline { 2 - 4 } & Veículo + LPS & $1,8 \pm 0,5 \boldsymbol{a}$ & $2,0 \pm 0,1$ \\
\cline { 2 - 4 } & CBD 20 + LPS & $1,2 \pm 0,2$ & $1,8 \pm 0,2$ \\
\hline \multirow{2}{*}{ Sangue (\%) } & Veículo + Sal & $2,3 \pm 0,04$ & $1,1 \pm 0,1$ \\
\cline { 2 - 4 } & Veículo + LPS & $1,9 \pm 0,1 \mathbf{a}$ & $1,5 \pm 0,1$ \\
\cline { 2 - 4 } & CBD 20 + LPS & $1,5 \pm 0,1 \mathbf{a} \boldsymbol{b}$ & $1,9 \pm 0,1 \boldsymbol{a} \boldsymbol{b}$ \\
\hline \multirow{2}{*}{ Baço (\%) } & Veículo + Sal & $3,3 \pm 0,1$ & $3,7 \pm 0,1$ \\
& Veículo + LPS & $3,1 \pm 0,2$ & $3,9 \pm 0,1$ \\
& CBD 20 + LPS & $4,6 \pm 0,2 \boldsymbol{a} \boldsymbol{b}$ & $3,9 \pm 0,1$ \\
\hline
\end{tabular}

Os dados representam a média \pm erro padrão, correspondente ao percentual de células $T$ regulatórias no LBA, no sangue e no baço. A letra a representa um $p<$ 0,05 quando comparado ao grupo veículo+sal e a letra $\boldsymbol{b}$ representa um $p<0,05$ quando comparado ao grupo veículo+LPS. Foi utilizado o teste estatístico ANOVA de uma via seguido do teste de Tukey-Kramer de comparações múltiplas, $n=5-10$ animais/grupo. 


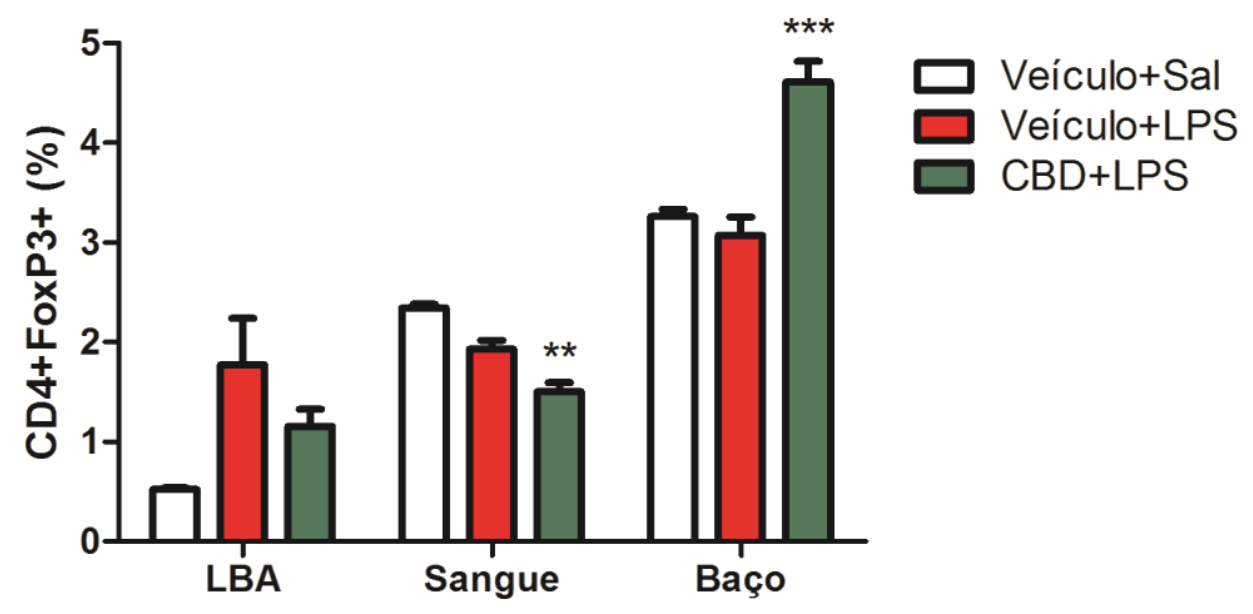

Figura 16 - Efeitos do CBD sobre o percentual de células Treg no LBA, no sangue e no baço de camundongos submetidos ao modelo de ALI, 1 dia após a indução da inflamação. ${ }^{* *} p<0,001 e^{* * *} p<0,0001$ quando comparados aos grupos veículo+sal e veículo+LPS. ANOVA de uma via seguido do teste de Tukey-Kramer de comparações múltiplas, $n=5-10$ animais/grupo

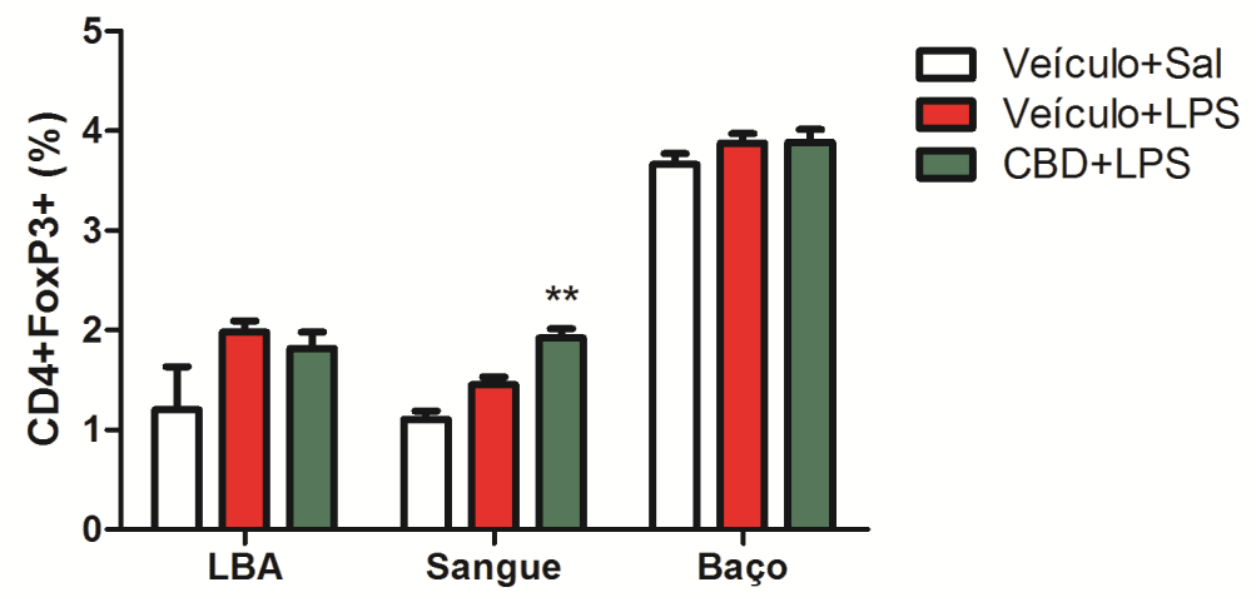

Figura 17 - Efeitos do CBD sobre o percentual de células Treg no LBA, no sangue e no baço de camundongos submetidos ao modelo de ALI, 2 dias após a indução da inflamação. ${ }^{* *} p<0,001$ quando comparados aos grupos veículo+sal e veículo+LPS. ANOVA de uma via seguido do teste de Tukey-Kramer de comparações múltiplas, $n=4-7$ animais/grupo 


\subsubsection{O CBD altera poucos parâmetros comportamentais no campo aberto}

As infecções ou modelos experimentais que mimetizam infecções são conhecidos por alterar parâmetros comportamentais, conhecido de maneira geral como comportamento doentio. Avaliamos se a inflamação pulmonar alteraria parâmetros comportamentais e se o tratamento com o CBD seria capaz de modificar tais alterações. Desta forma, avaliamos o comportamento dos animais no campo aberto 6 e 24 h após a indução da inflamação. Para o experimento de 6 h, 36 camundongos foram separados ao acaso em 4 grupos (veículo+sal, veículo+LPS, CBD 20+sal e CBD 20+LPS); os animais receberam uma dose de CBD ou veículo (i.p.), 60 min após foram submetidos a nebulização com solução salina ou LPS, conforme item 4.3. Para o experimento de $24 \mathrm{~h}, 19$ camundongos foram separados ao acaso em 3 grupos (veículo+sal, veículo+LPS, CBD 20+LPS); os animais receberam uma dose de CBD ou veículo (i.p.), $60 \mathrm{~min}$ após foram anestesiados e receberam solução salina ou LPS por via intra-nasal. Foram utilizados 2 protocolos experimentais diferentes para cada experimento, principalmente devido ao tratamento com anestésico.

\section{RESULTADOS:}

A tabela 13 mostra os efeitos do tratamento com o CBD, 6 h após a indução da inflamação. Os resultados obtidos nos experimentos comportamentais revelaram-se bastante sutís. A ANOVA de duas vias mostrou que não houve qualquer efeito comportamental oriundo da inflamação pulmonar após $6 \mathrm{~h}$ da indução da ALI (fator inflamação). No entanto, quando se levou em consideração somente 0 fator tratamento, o CBD aumentou a distância movida $(F(3,39)=4,8 ; p<0,05)$ e o tempo na zona central $(F(3,39)=7,7 ; p<0,05)$ do campo aberto. Quando se levou em consideração o tratamento entre os animais nebulizados com salina (veículo+sal e CBD 20+sal), o CBD aumentou a distância movida $(F(3,39)=4,8 ; p<0,05)$ no campo aberto. Quando se levou em consideração o tratamento entre os animais nebulizados com LPS (veículo+LPS e CBD 20+LPS), o CBD aumentou o tempo gasto na zona central $(F(3,39)=7,7 ; p<0,05)$ do campo aberto. Não se observou 
diferenças significantes no tempo gasto na zona periférica e na velocidade média dos animais no campo aberto.

Tabela 13 - Efeitos do CBD sobre parâmetros comportamentais no campo aberto de camundongos submetidos ao modelo de ALI, $6 \mathrm{~h}$ após a indução da inflamação

\section{Parâmetros}

\begin{tabular}{|c|cccc}
\cline { 2 - 5 } Grupos & $\begin{array}{c}\text { Distância } \\
\text { movida }(\mathbf{c m})\end{array}$ & $\begin{array}{c}\text { Tempo zona } \\
\text { periférica }(\mathbf{s})\end{array}$ & $\begin{array}{c}\text { Tempo zona } \\
\text { central }(\mathbf{s})\end{array}$ & $\begin{array}{c}\text { Velocidade } \\
\text { média }(\mathbf{c m} / \mathbf{s})\end{array}$ \\
\hline Veículo + Sal & $2173 \pm 118$ & $254 \pm 4,1$ & $42 \pm 3,1$ & $7,3 \pm 0,4$ \\
\hline CBD 20 + Sal & $2457 \pm 88 \mathbf{a c}$ & $251 \pm 5,6$ & $48 \pm 5,6 \mathbf{c}$ & $8,5 \pm 0,3$ \\
\hline Veículo + LPS & $2117 \pm 97$ & $254 \pm 5,1$ & $41 \pm 2,5$ & $7,6 \pm 0,4$ \\
\hline CBD 20 + LPS & $2256 \pm 62 \mathbf{c}$ & $238 \pm 5,5$ & $60 \pm 5,6 \mathbf{b} \mathbf{c}$ & $7,6 \pm 0,2$ \\
\hline
\end{tabular}

Os dados representam a média \pm erro padrão, correspondente a parâmetros comportamentais no campo aberto. A letra a representa um $p<0,05$ quando comparado ao grupo veículo+sal, a $\boldsymbol{b}$ representa um $\mathrm{p}<0,05$ quando comparado ao grupo veículo+LPS e a letra $c$ representa um $p<0,05$ quando se compara os grupos tratados com CBD (CBD+sal e CBD+LPS) com os grupos tratados com veículo (veículo+sal e veículo+LPS). Foi utilizado o teste estatístico ANOVA de duas vias seguido do teste de Student-Newman-Keuls de comparações múltiplas, $\mathrm{n}=8-12$ animais/grupo. 
A tabela 14 mostra os efeitos do tratamento com CBD 24 h após a indução da inflamação. Novamente, os resultados obtidos neste experimento comportamental acabaram por se mostrar bastante sutís. A ANOVA de uma via revelou que o grupo dos animais inflamados (veículo+LPS) apresentavam uma diminuição da distância movida $(F(2,16)=3,9 ; p<0,05)$ e da velocidade média $(F(2,16)=3,8 ; p<0,05)$ no campo aberto. $O$ tratamento com o CBD reestabeleceu a ambulação $(F(2,16)=3,9$; $p<0,05)$ e a velocidade média $(F(2,16)=3,8 ; p<0,05)$ no campo aberto $24 \mathrm{~h}$ após a indução da inflamação. Não se observou qualquer diferença significante entre os grupos no tempo gasto na zona periférica $(F(2,16)=0,3 ; p=0,8)$ e na zona central $(F(2,16)=0,3 ; p=0,8)$ do campo aberto.

Tabela 14 - Efeitos do CBD sobre parâmetros comportamentais no campo aberto de camundongos submetidos ao modelo de ALI, $24 \mathrm{~h}$ após a indução da inflamação

\section{Parâmetros}

\begin{tabular}{c|cccc}
\hline Grupos & $\begin{array}{c}\text { Distância } \\
\text { movida (cm) }\end{array}$ & $\begin{array}{c}\text { Tempo zona } \\
\text { periférica }(\mathbf{s})\end{array}$ & $\begin{array}{c}\text { Tempo zona } \\
\text { central (s) }\end{array}$ & $\begin{array}{c}\text { Velocidade } \\
\text { média (cm/s) }\end{array}$ \\
\hline Veículo + Sal & $1455 \pm 67$ & $243 \pm 14$ & $57 \pm 14$ & $4,9 \pm 0,2$ \\
\hline Veículo + LPS & $1303 \pm 84$ & $256 \pm 10$ & $44 \pm 10$ & $4,2 \pm 0,3$ \\
\hline CBD 20 + LPS & $1608 \pm 77 \boldsymbol{b}$ & $250 \pm 10$ & $50 \pm 10$ & $5,4 \pm 0,3 \boldsymbol{b}$ \\
\hline
\end{tabular}

Os dados representam a média \pm erro padrão, correspondente aos parâmetros comportamentais no campo aberto. A letra a representa um $p<0,05$ quando comparado ao grupo veículo+sal e a letra $\boldsymbol{b}$ representa um $p<0,05$ quando comparado ao grupo veículo+LPS. Foi utilizado o teste estatístico ANOVA de uma via seguido do teste de Tukey-Kramer de comparações múltiplas, $n=5-9$ animais/grupo. 
Pensamos que seria interessante avaliar se a inflamação pulmonar induzida por LPS aumentaria os níveis séricos de corticosterona e se o tratamento com o CBD teria alguma influência neste aumento. Desta forma, avaliamos os níveis de corticosterona, 6 e $24 \mathrm{~h}$ após a indução da ALI. Para tanto, 72 camundongos foram separados ao acaso em 4 grupos (veículo+sal, veículo+LPS, CBD 20+sal e CBD 20+LPS) e avaliados 6 e $24 \mathrm{~h}$ após a indução da inflamação. Brevemente, os animais receberam uma dose de CBD ou veículo (i.p.), 60 min após foram submetidos a nebulização, conforme item 4.3 , de solução salina ou LPS.

\section{RESULTADOS:}

A tabela 15 mostra os efeitos do tratamento com o CBD nos níveis de corticosterona, $6 \mathrm{~h}$ e $24 \mathrm{~h}$ após a indução da inflamação. A ANOVA de duas vias revelou que não houve qualquer efeito a atividade do eixo HPA em decorrência da inflamação pulmonar (fator inflamação) $(F(3,40)=0,6 ; p=0,5)$. Da mesma maneira, o fator tratamento não modificou a atividade do eixo $\operatorname{HPA}(F(3,40)=2,7 ; p=0,1)$. Por fim, não houve qualquer tipo de interação entre o fator tratamento e o fator inflamação $(F(3,40)=0,5 ; p=0,5)$. 
Tabela 15 - Efeitos do CBD sobre a ativação do eixo HPA de camundongos submetidos ao modelo de ALI, 6 e 24 h após a indução da inflamação

Corticosterona $(\mathrm{ng} / \mathrm{mL})$

\begin{tabular}{|c|cc|}
\hline Grupos & $\mathbf{6 ~ h}$ & $\mathbf{2 4} \mathbf{~}$ \\
\hline Veículo + Sal & $234 \pm 19$ & $182 \pm 21$ \\
\hline CBD 20 + LPS & $219 \pm 14$ & $186 \pm 11$ \\
\hline Veículo + LPS & $232 \pm 14$ & $189 \pm 14$ \\
\hline CBD 20 + LPS & $197 \pm 13$ & $194 \pm 11$ \\
\hline
\end{tabular}

Os dados representam a média \pm erro padrão, correspondente à concentração de corticosterona no soro. Foi utilizado o teste estatístico ANOVA de duas vias seguido do teste de Student-Newman-Keuls de comparações múltiplas, $n=8-12$ animais/grupo. 


\subsection{Tratamento terapêutico com CBD}

Após a análise de todos os resultados envolvendo o tratamento profilático com CBD no modelo murino de ALI, decidimos avaliar os efeitos do tratamento terapêutico com CBD no mesmo modelo.

5.2.1 O tratamento terapêutico com CBD diminui a migração de leucócitos para os pulmões

Neste ponto do trabalho decidimos analisar, utilizando o protocolo de tratamento terapêutico, a migração de leucócitos para os pulmões. Quantificamos a presença de neutrófilos, macrófagos/monócitos e linfócitos no LBA dos animais submetidos à inflamação pulmonar. Assim, investigamos os efeitos do CBD 20 e 80 $\mathrm{mg} / \mathrm{kg}$ na migração de leucócitos para os pulmões, 1 e 2 dias após a indução da ALI. Para tanto, cinquenta e quatro camundongos foram separados ao acaso em 4 grupos (sal+veículo, LPS+ veículo, LPS+ CBD 20, LPS+CBD 80) e avaliados 1 e 2 dias após a indução da inflamação. Brevemente, os animais foram anestesiados e receberam solução salina ou LPS por via intra-nasal. Decorridas $6 \mathrm{~h}$, os animais receberam uma dose de CBD ou veículo (i.p.). Veja a representação esquemática abaixo, figura 18. 


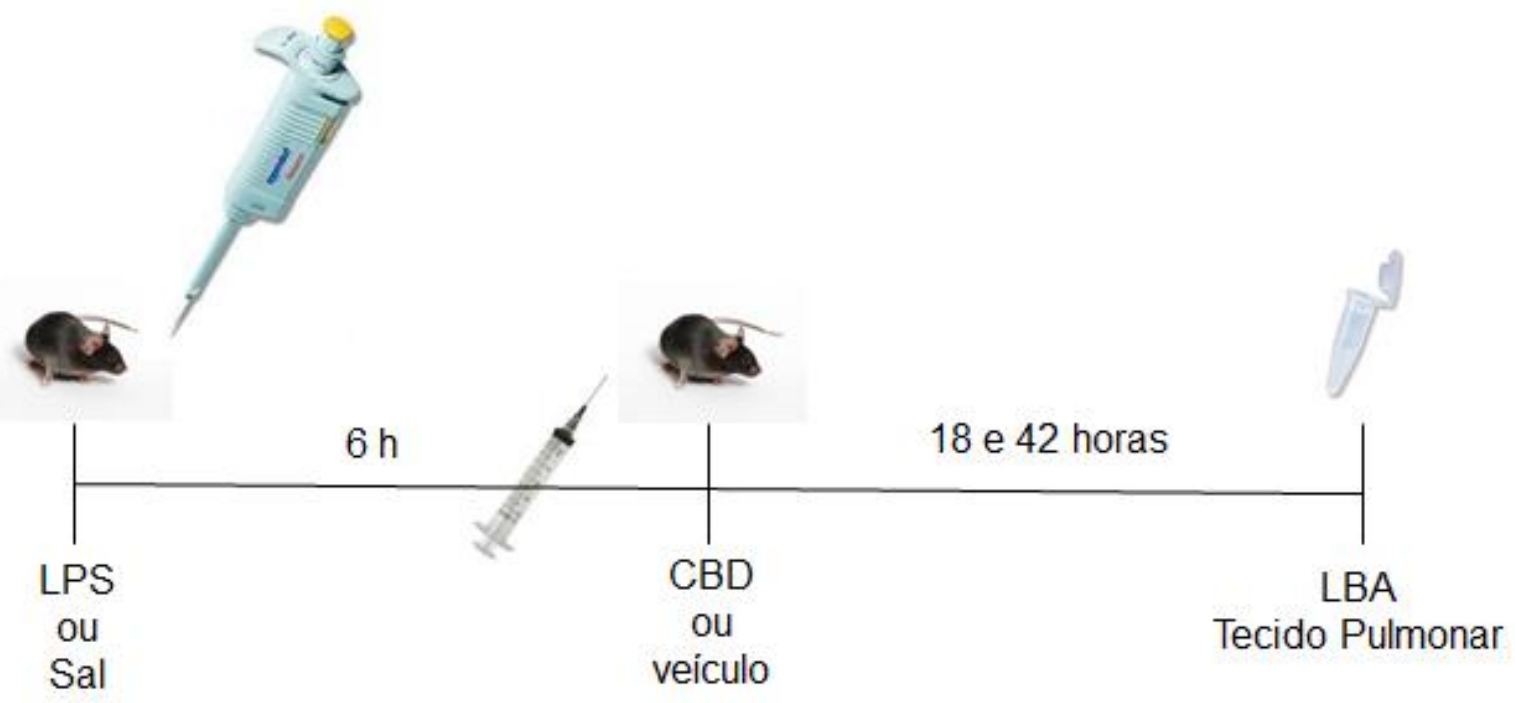

Figura 18 - Representação esquemática do protocolo experimental terapêutico de tratamento e indução da inflamação pulmonar

\section{RESULTADOS:}

A tabela 16 mostra os efeitos do tratamento terapêutico com CBD nas doses de 20 e $80 \mathrm{mg} / \mathrm{kg}$ na migração de leucócitos totais para os pulmões de animais submetidos ao modelo de ALI. Observa-se que a instilação intra-nasal com LPS aumentou de forma significativa a contagem total de leucócitos no LBA nos animais do grupo controle inflamado (LPS+veículo), $1(F(3,22)=20,0 p<0,0001)$ e 2 ( $F$ $(3,24)=13,0 ; p<0,0001)$ dias após a indução da inflamação pulmonar (Figura 19). Observa-se, ainda, que o tratamento com o CBD, nas doses de 20 e $80 \mathrm{mg} / \mathrm{kg}$, diminuiu a contagem de leucócitos, $1(F(3,22)=20,0 p<0,0001)$ e $2(F(3,24)=$ 13,$0 ; p<0,001$ ) dias após a indução da inflamação pulmonar (Figura 19). 
Tabela 16 - Efeitos do tratamento terapêutico com o CBD sobre a migração de leucócitos para os pulmões de camundongos submetidos ao modelo de ALI

LBA ( $n$ ㅇ de células $\times 10^{5}$ )

\begin{tabular}{c|cc} 
Grupos & $\mathbf{1}$ dia & $\mathbf{2}$ dias \\
\hline Sal + Veículo & $1,1 \pm 0,1$ & $1,3 \pm 0,3$ \\
\hline LPS + Veículo & $25,5 \pm 3,9 \boldsymbol{a}$ & $9,1 \pm 1,2 \boldsymbol{a}$ \\
\hline LPS + CBD 20 & $10,1 \pm 1,7 \boldsymbol{a} \boldsymbol{b}$ & $3,9 \pm 0,7 \boldsymbol{b}$ \\
\hline LPS + CBD 80 & $9,5 \pm 0,7 \boldsymbol{b}$ & $4,1 \pm 0,5 \boldsymbol{b}$ \\
\hline
\end{tabular}

Os dados representam a média \pm erro padrão, correspondente à contagem total de leucócitos no LBA. A letra a representa um $p<0,05$ quando comparado ao grupo sal+veículo e a letra $\boldsymbol{b}$ representa um $\mathrm{p}<0,05$ quando comparado ao grupo LPS+veículo. Foi utilizado o teste estatístico ANOVA de uma via seguido do teste de Tukey-Kramer de comparações múltiplas, $n=4-9$ animais/grupo.

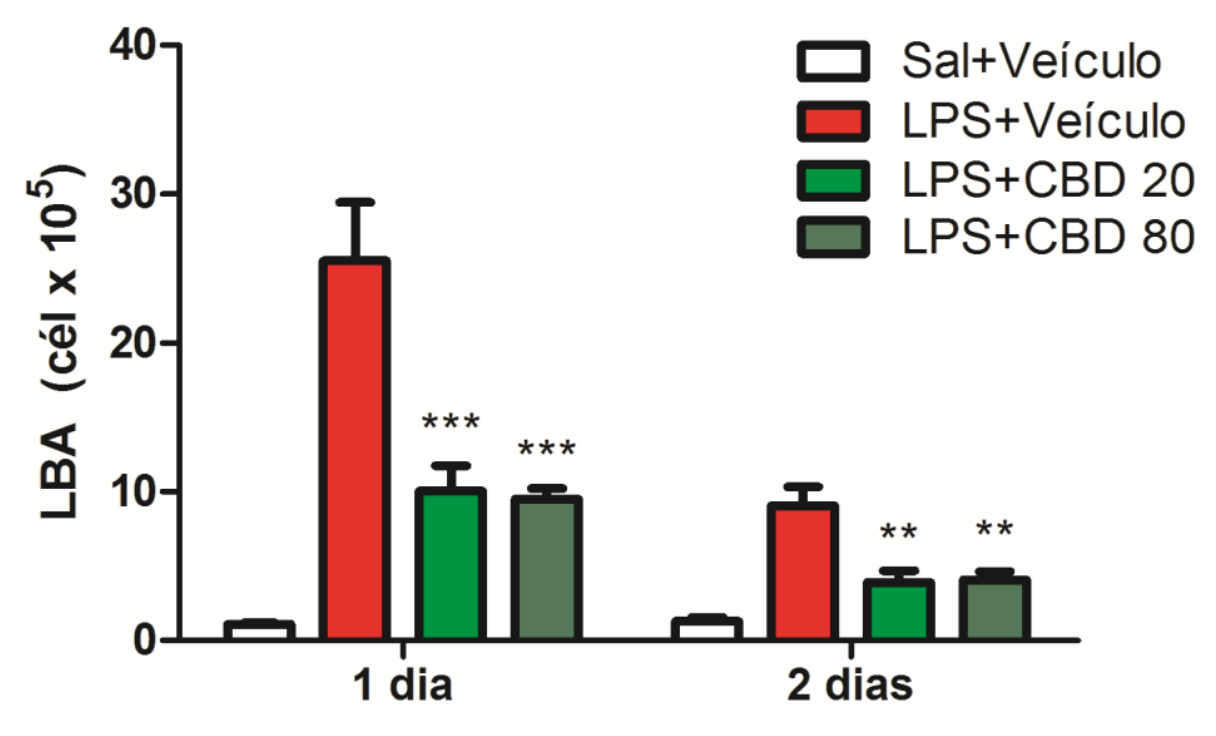

Figura 19 - Efeitos do tratamento terapêutico com CBD sobre a migração de leucócitos para os pulmões de camundongos submetidos ao modelo murino de ALI, 1 e 2 dias após a indução da inflamação. ** $p<0,001$ e ${ }^{* * *} p<0,0001$ quando comparados ao grupo LPS+veículo. ANOVA de uma via seguido do teste de Tukey-Kramer de comparações múltiplas, $\mathrm{n}=4-9$ animais/grupo 
Analisamos, também, a contagem diferencial de leucócitos no LBA. A tabela 17 mostra que 1 dia após a indução da inflamação, o CBD nas doses de 20 e $80 \mathrm{mg} / \mathrm{kg}$, diminuiu a migração de neutrófilos $(F(3,22)=16,3, p<0,0001)$ e macrófagos ( $F$ $(3,22)=11,1, p<0,0001$ e $p<0,001)$ para os pulmões; com relação aos linfócitos, somente a dose de $80 \mathrm{mg} / \mathrm{kg}$ foi capaz de diminuir a migração de leucócitos para os pulmões $(F(3,22)=4,7, p<0,05), 1$ dia após a indução da inflamação. Após 2 dias da indução da inflamação, observamos que o CBD nas doses de 20 e $80 \mathrm{mg} / \mathrm{kg}$, diminuiu a migração de neutrófilos $(F(3,23)=13,1, p<0,001)$ para os pulmões. Além disso, o tratamento com o CBD na dose de $20 \mathrm{mg} / \mathrm{kg}$ diminuiu a migração de macrófagos $(F(3,23)=4,2, p<0,05)$ para os pulmões, 2 dias após a indução da inflamação. Não se observou qualquer alteração com relação aos linfócitos 2 dias após a inflamação. 
Tabela 17 - Efeitos do tratamento terapêutico com CBD sobre a contagem de diferencial de leucócitos no LBA de camundongos submetidos ao modelo de ALI

Contagem diferencial de Leucócitos no LBA

\begin{tabular}{|c|c|c|c|}
\hline Tipo celular & Grupos & 1 dia & 2 dias \\
\hline \multirow{4}{*}{ 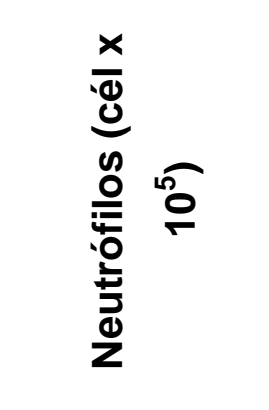 } & Sal + Veículo & $0,2 \pm 0,1$ & $0,2 \pm 0,1$ \\
\hline & LPS + Veículo & $23 \pm 3,8 a$ & $7,0 \pm 1,0 a$ \\
\hline & LPS + CBD 20 & $8,8 \pm 1,8 \boldsymbol{a} \boldsymbol{b}$ & $2,7 \pm 0,7 \boldsymbol{b}$ \\
\hline & LPS + CBD 80 & $8,1 \pm 0,7 \boldsymbol{b}$ & $2,4 \pm 0,4 \boldsymbol{b}$ \\
\hline \multirow{4}{*}{ 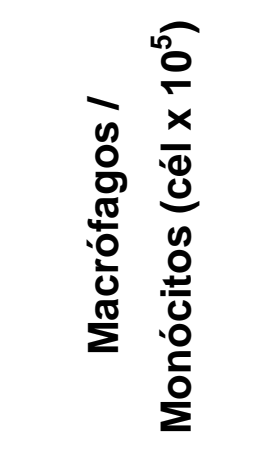 } & Sal + Veículo & $0,9 \pm 0,1$ & $0,8 \pm 0,1$ \\
\hline & LPS + Veículo & $2,5 \pm 0,3 a$ & $1,8 \pm 0,3 a$ \\
\hline & LPS + CBD 20 & $1,0 \pm 0,2 \boldsymbol{b}$ & $0,9 \pm 0,1 \boldsymbol{b}$ \\
\hline & LPS + CBD 80 & $1,2 \pm 0,1 \boldsymbol{b}$ & $1,3 \pm 0,1$ \\
\hline \multirow{4}{*}{ 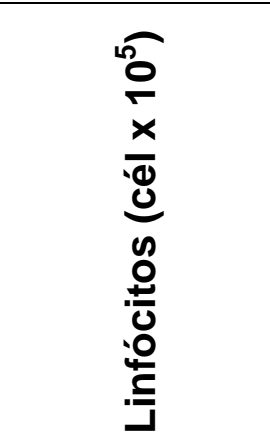 } & Sal + Veículo & $0,02 \pm 0,01$ & $0,2 \pm 0,1$ \\
\hline & LPS + Veículo & $0,5 \pm 0,1 a$ & $0,3 \pm 0,1$ \\
\hline & LPS + CBD 20 & $0,2 \pm 0,1$ & $0,3 \pm 0,1$ \\
\hline & LPS + CBD 80 & $0,2 \pm 0,1 \boldsymbol{b}$ & $0,3 \pm 0,2$ \\
\hline
\end{tabular}

Os dados representam a média \pm erro padrão, correspondente à contagem diferencial de leucócitos no LBA. A letra a representa um $p<0,05$ quando comparado ao grupo sal+veículo e a letra $\boldsymbol{b}$ representa um $p<0,05$ quando comparado ao grupo LPS+veículo. Foi utilizado o teste estatístico ANOVA de uma via seguido do teste de Tukey-Kramer de comparações múltiplas, $\mathrm{n}=4-9$ animais/grupo. 
5.2.2 O tratamento terapêutico com CBD não altera a distribuição de leucócitos na medula óssea e no sangue

Analisamos os efeitos do tratamento terapêutico com CBD 20 e 80 mg/kg sobre a distribuição de leucócitos no sangue e na medula óssea. Assim, foram coletados a medula óssea e o sangue dos mesmos cinquenta e quatro camundongos do experimento do item 5.2.1.

\section{RESULTADOS:}

A tabela 18 mostra que não foi observada qualquer alteração significante entre os grupos, em nenhum dos períodos de tempo analisados tanto na medula óssea ( $F$ $(3,22)=2,8, p=0,06$ (1 dia); $F(3,23)=0,1, p=0,9$ (2 dias)) como no sangue ( $F$ $(3,22)=0,3, p=0,8(1 \mathrm{dia}) ; F(3,23)=0,9, p=0,5$ (2 dias)) . 
Tabela 18 - Efeitos do tratamento terapêutico com CBD sobre a distribuição de leucócitos na medula óssea e no sangue de camundongos submetidos ao modelo de ALI

\section{Distribuição de leucócitos}

\begin{tabular}{|c|c|c|c|}
\hline Compartimento & Grupos & 1 dia & 2 dias \\
\hline \multirow{4}{*}{ 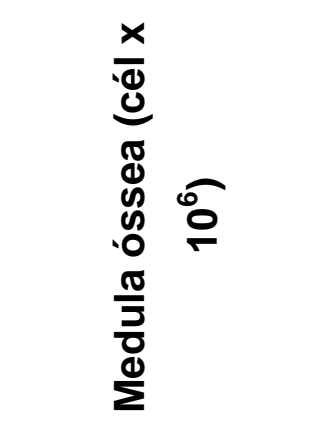 } & Sal + Veículo & $3,5 \pm 3,1$ & $3,7 \pm 5,5$ \\
\hline & LPS + Veículo & $3,9 \pm 4,1$ & $3,9 \pm 1,1$ \\
\hline & LPS + CBD 20 & $4,7 \pm 2,3$ & $4,0 \pm 4,8$ \\
\hline & LPS + CBD 80 & $4,7 \pm 3,3$ & $3,8 \pm 3,5$ \\
\hline \multirow{4}{*}{ 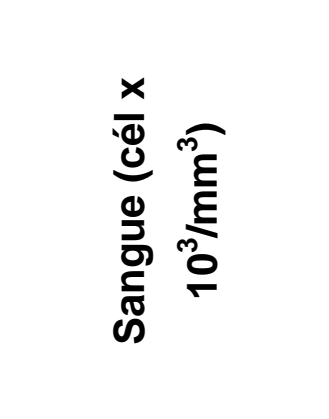 } & Sal + Veículo & $3,7 \pm 0,8$ & $3,8 \pm 0,1$ \\
\hline & LPS + Veículo & $3,1 \pm 0,2$ & $3,5 \pm 0,3$ \\
\hline & LPS + CBD 20 & $3,3 \pm 0,5$ & $2,7 \pm 0,4$ \\
\hline & LPS + CBD 80 & $3,7 \pm 0,4$ & $3,9 \pm 0,6$ \\
\hline
\end{tabular}

Os dados representam a média \pm erro padrão, correspondente à contagem total de leucócitos na medula óssea e no sangue. Foi utilizado o teste estatístico ANOVA de uma via seguido do teste de Tukey-Kramer de comparações múltiplas, $n=4-9$ animais/grupo. 


\subsubsection{O tratamento terapêutico com CBD diminui a atividade de mieloperoxidase (MPO) no tecido pulmonar}

Novamente, analisamos a atividade de MPO, como uma medida indireta da atividade de neutrófilos no tecido pulmonar, 1 e 2 dias após a indução da inflamação. Para tanto, cinquenta e dois camundongos foram separados ao acaso em 4 grupos (sal+veículo, LPS+ veículo, LPS+ CBD 20, LPS+CBD 80) e avaliados 1 e 2 dias após a indução da inflamação. Brevemente, os animais foram anestesiados e receberam solução salina ou LPS por via intra-nasal. Decorridas $6 \mathrm{~h}$, os animais receberam uma dose de CBD ou veículo (i.p.). Para efeito de análise estatística, os dados de atividade de MPO foram analisados utilizando o teste de Kruskal-Wallis seguido do teste de Dunn de comparações múltiplas, após os valores terem sido normalizados como percentual do grupo controle não inflamado (sal+veículo).

\section{RESULTADOS:}

A tabela 19 mostra e a figura 20 ilustra que o tratamento terapêutico com CBD na dose de $80 \mathrm{mg} / \mathrm{kg}$ diminuiu a atividade de MPO, 1 ( $\mathrm{KW}=9,7 ; \mathrm{p}<0,001)$ e 2 (KW $=9,9 ; p<0,001)$ dias após a indução da inflamação. Ao se avaliar os resultados após a dose de $20 \mathrm{mg} / \mathrm{kg}$, observa- se uma diminuição da atividade de MPO que, no entanto, não foi estatisticamente significante. 
Tabela 19 - Efeito do tratamento terapêutico com o CBD sobre a atividade de MPO no tecido pulmonar de camundongos submetidos ao modelo de ALI

Atividade de MPO (\% controle)

\begin{tabular}{c|cc}
\hline Grupos & $\mathbf{1}$ dia & 2 dias \\
\hline LPS + Veículo & $380 \pm 53$ & $151 \pm 10$ \\
\hline LPS + CBD 20 & $239 \pm 26$ & $110 \pm 5$ \\
\hline LPS + CBD 80 & $175 \pm 6 \boldsymbol{b}$ & $102 \pm 6 \boldsymbol{b}$ \\
\hline
\end{tabular}

Os dados representam a média \pm erro padrão, correspondente à atividade de MPO no tecido pulmonar. A letra $\boldsymbol{b}$ representa um $p<0,05$ quando comparado ao grupo LPS+veículo. Foi utilizado o teste estatístico Kruskal-Wallis seguido do teste de Dunn de comparações múltiplas, $n=4-9$ animais/grupo.

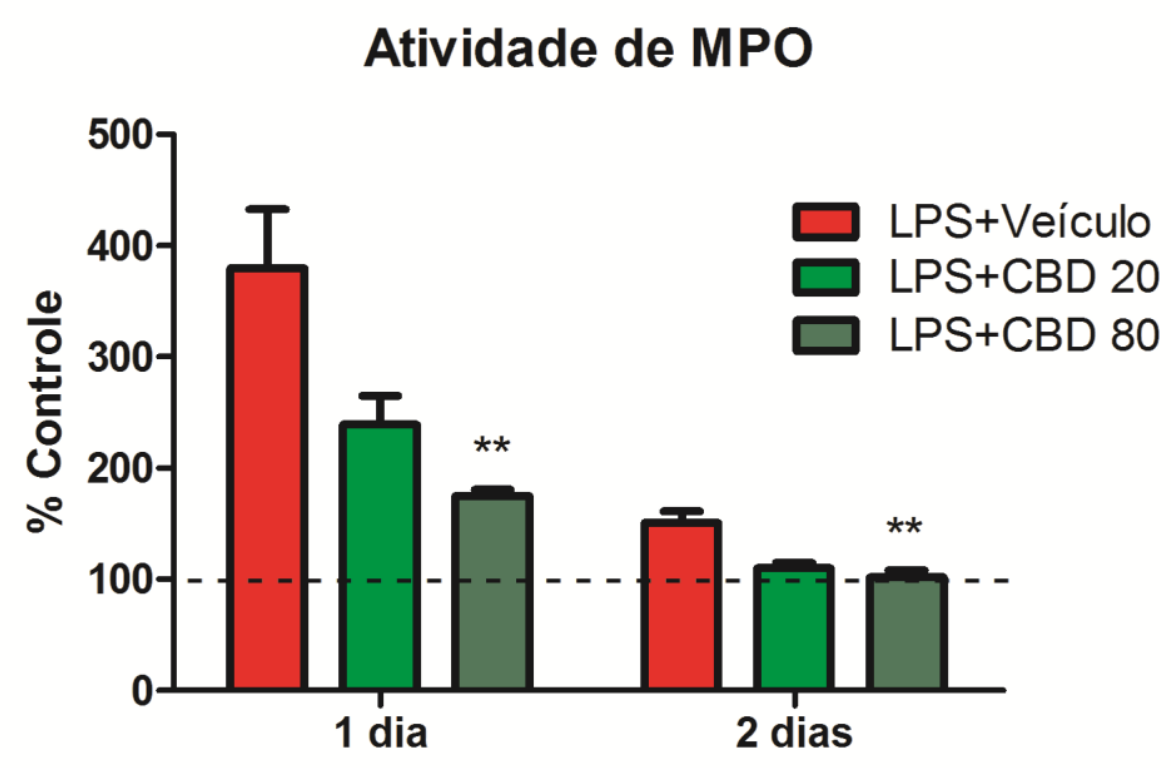

Figura 20 - Efeitos do tratamento terapêutico com CBD sobre a atividade de MPO no tecido pulmonar de camundongos submetidos ao modelo murino de $\mathrm{ALI}, 1$ e 2 dias após a indução da inflamação. ${ }^{* *} p<0,001$ quando comparados ao grupo LPS+veículo. Kruskal-Wallis seguido do teste de Dunn de comparações múltiplas, $n=4-9$ animais/grupo 
5.2.4 O tratamento terapêutico com $C B D$ diminui a produção de citocinas $e$ quimiocinas pró-inflamatórias no LBA

Investigamos, ainda, os efeitos do tratamento terapêutico com CBD sobre a concentração de citocinas e quimiocinas pró-inflamatórias no LBA, 1 e 2 dias após a indução da inflamação. Para tanto, cinquenta e dois camundongos foram separados ao acaso em 4 grupos (sal+veículo, LPS+ veículo, LPS+ CBD 20, LPS+CBD 80) e avaliados 1 e 2 dias após a indução da inflamação. Brevemente, os animais foram anestesiados e receberam solução salina ou LPS por via intra-nasal. Decorridas $6 \mathrm{~h}$, os animais receberam uma dose de CBD ou veículo (i.p.).

\section{RESULTADOS:}

A tabela 20 mostra que, 1 dia após a indução da inflamação, o CBD $20 \mathrm{mg} / \mathrm{kg}$ diminuiu a produção de TNF $(F(3,23)=14,5 ; p<0,05)$ e MIP-2 $(F(3,22)=32,9 ; p<$ $0,0001)$ no LBA. Ainda, 1 dias após a indução da inflamação, o CBD $80 \mathrm{mg} / \mathrm{kg}$ diminuiu a produção de TNF ( $F(3,23)=14,5 ; p<0,0001)$, IL-6 $(F(3,23)=11,5 ; p<$ $0,05)$, MCP-1 $(F(3,23)=5,6 ; p<0,05)$ e MIP-2 $(F(3,22)=32,9 ; p<0,0001)$ no LBA. Adicionalmente, 2 dias após a indução da inflamação, o CBD $20 \mathrm{mg} / \mathrm{kg}$ diminuiu a produção de TNF ( $F(3,22)=5,6 ; p<0,05)$, IL-6 $(F(3,22)=6,9 ; p<0,001)$ e MIP-2 $(F(3,23)=9,4 ; p<0,001)$ no LBA. Já o CBD $80 \mathrm{mg} / \mathrm{kg}$ diminuiu a produção de IL-6 $(F(3,22)=6,9 ; p<0,05), M C P-1(F(3,22)=4,2 ; p<0,05)$ e MIP-2(F $(3,23)=9,4 ; p$ $<0,05)$ no LBA (Figura 21). 
Tabela 20 - Efeitos do tratamento terapêutico com CBD sobre a produção de citocina e quimiocinas no LBA de camundongos submetidos ao modelo de ALI

(Continua)

Produção de citocinas e quimiocinas no LBA

\begin{tabular}{|c|c|c|c|}
\hline $\begin{array}{l}\text { Citocinas e } \\
\text { Quimiocinas }\end{array}$ & Grupos & 1 dia & 2 dias \\
\hline \multirow{4}{*}{ 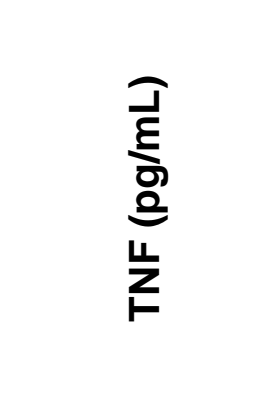 } & Sal + Veículo & $5,7 \pm 0,4$ & $8 \pm 0,5$ \\
\hline & LPS + Veículo & $194 \pm 30 a$ & $41 \pm 10 a$ \\
\hline & LPS + CBD 20 & $96 \pm 17 \boldsymbol{a} b$ & $14 \pm 3,3 \boldsymbol{b}$ \\
\hline & LPS + CBD 80 & $71 \pm 17 \boldsymbol{b}$ & $18 \pm 3,5$ \\
\hline \multirow{4}{*}{ 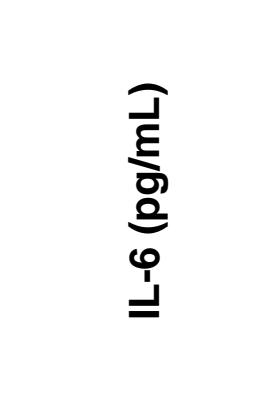 } & Sal + Veículo & $1,6 \pm 0,1$ & $2,6 \pm 0,1$ \\
\hline & LPS + Veículo & $89 \pm 14 a$ & $12 \pm 2,7 a$ \\
\hline & LPS + CBD 20 & $64 \pm 13 a$ & $4,0 \pm 0,5 \boldsymbol{b}$ \\
\hline & LPS + CBD 80 & $41 \pm 9 b$ & $5,8 \pm 1,3 \boldsymbol{b}$ \\
\hline \multirow{4}{*}{ 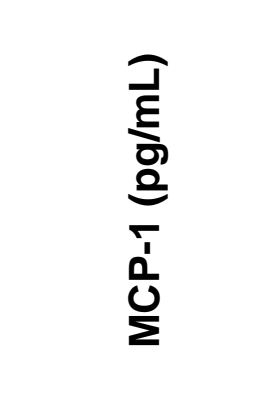 } & Sal + Veículo & $9 \pm 2$ & $20 \pm 2,7$ \\
\hline & LPS + Veículo & $65 \pm 19 a$ & $54 \pm 13 a$ \\
\hline & LPS + CBD 20 & $25 \pm 5$ & $28 \pm 2,5$ \\
\hline & LPS + CBD 80 & $24 \pm 2 b$ & $25 \pm 2,7 \boldsymbol{b}$ \\
\hline \multirow{4}{*}{ 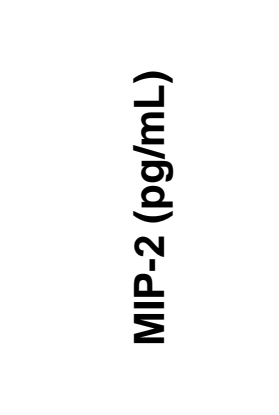 } & Sal + Veículo & $0 \pm 0$ & $0,4 \pm 0,3$ \\
\hline & LPS + Veículo & $206 \pm 22 a$ & $23 \pm 4,7 a$ \\
\hline & LPS + CBD 20 & $60 \pm 12 b$ & $6,8 \pm 1,9 \boldsymbol{b}$ \\
\hline & LPS + CBD 80 & $65 \pm 5,3 \boldsymbol{b}$ & $8,4 \pm 2,2 \boldsymbol{b}$ \\
\hline
\end{tabular}


(Conclusão)

\begin{tabular}{|c|c|c|c|}
\hline $\begin{array}{l}\text { Citocinas e } \\
\text { Quimiocinas }\end{array}$ & Grupos & 1 dia & 2 dias \\
\hline \multirow{4}{*}{ 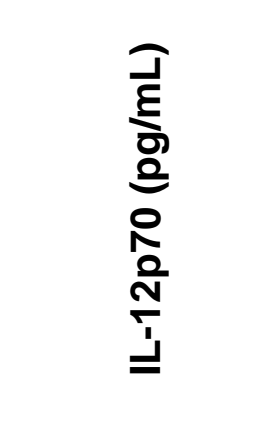 } & Sal + Veículo & $2,3 \pm 0,8$ & $5,6 \pm 0,4$ \\
\hline & LPS + Veículo & $6,7 \pm 1,7$ & $7,4 \pm 0,4$ \\
\hline & LPS + CBD 20 & $5,5 \pm 1,1$ & $7,6 \pm 0,8$ \\
\hline & LPS + CBD 80 & $5,4 \pm 0,5$ & $6,0 \pm 1,2$ \\
\hline \multirow{4}{*}{ 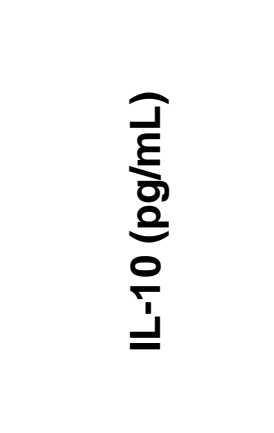 } & Sal + Veículo & $6,4 \pm 3,4$ & $16 \pm 2,0$ \\
\hline & LPS + Veículo & $20 \pm 5,4$ & $21 \pm 1,7$ \\
\hline & LPS + CBD 20 & $15 \pm 2,5$ & $24 \pm 3,5$ \\
\hline & LPS + CBD 80 & $17 \pm 2,0$ & $17 \pm 3,1$ \\
\hline \multirow{4}{*}{ 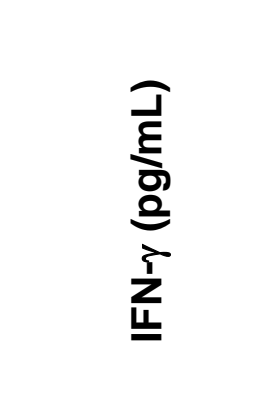 } & Sal + Veículo & $1,3 \pm 0,1$ & $1,8 \pm 0,1$ \\
\hline & LPS + Veículo & $2,1 \pm 0,3 \mathbf{a}$ & $3,5 \pm 0,7 a$ \\
\hline & LPS + CBD 20 & $1,6 \pm 0,1$ & $2,0 \pm 0,2$ \\
\hline & LPS + CBD 80 & $1,8 \pm 0,1$ & $2,1 \pm 0,2$ \\
\hline
\end{tabular}

Os dados representam a média \pm erro padrão, correspondente à concentração de citocinas e quimiocinas no LBA. A letra a representa um $p<0,05$ quando comparado ao grupo sal+veículo e a letra $\boldsymbol{b}$ representa um $p<0,05$ quando comparado ao grupo LPS+veículo. Foi utilizado o teste estatístico ANOVA de uma via seguido do teste de Tukey-Kramer de comparações múltiplas, $\mathrm{n}=4-9$ animais/grupo. 

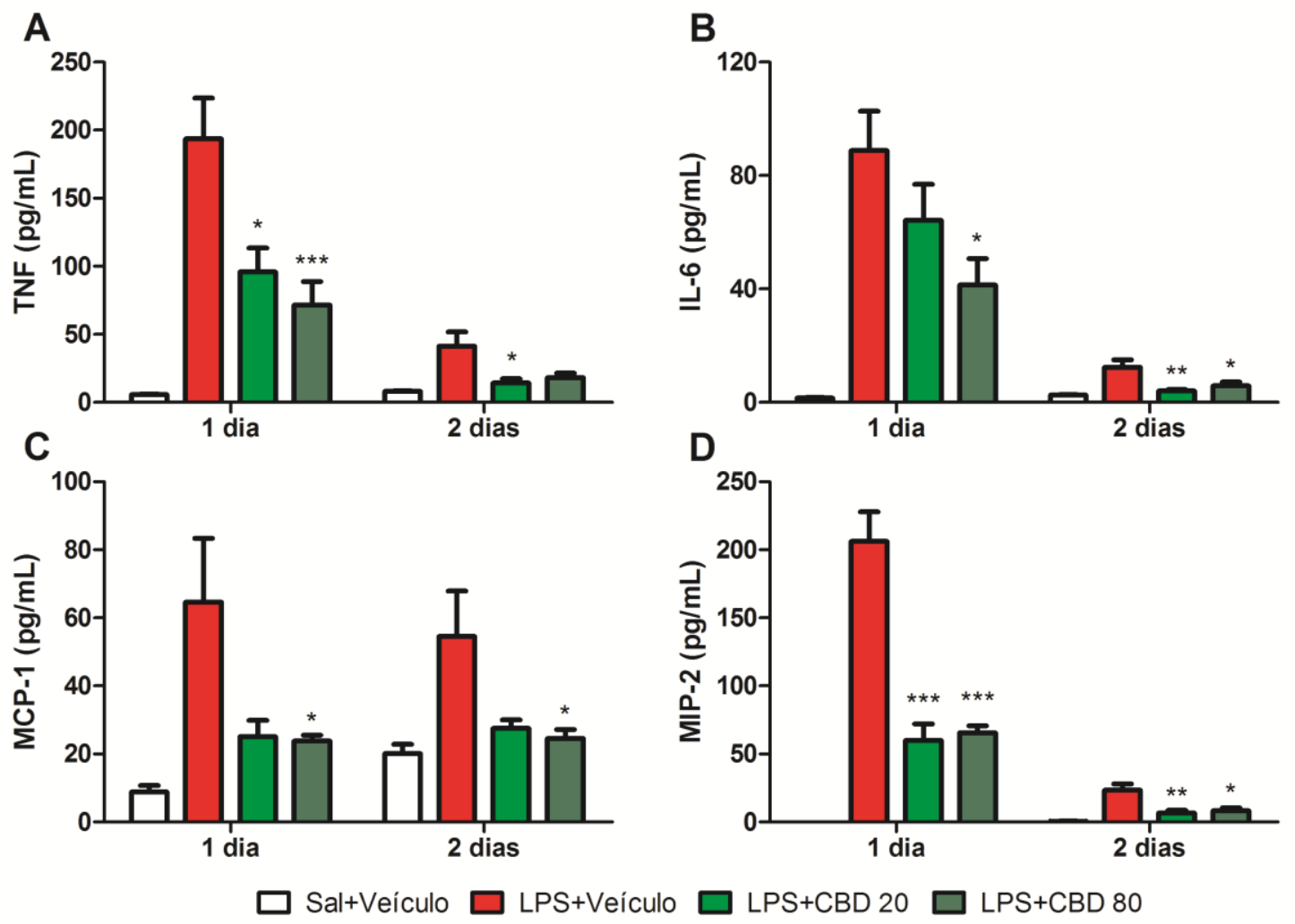

Figura 21 - Efeitos do tratamento terapêutico com CBD sobre a produção de citocinas e quimiocinas em camundongos submetidos ao modelo de ALI. (A) TNF, (B) IL-6, (C) MCP-1 e (D) MIP-2. * $p<0,05,{ }^{* *} p<0,001$ e ${ }^{* * *} p<0,0001$ quando comparados ao grupo veículo+LPS. ANOVA de uma via seguido do teste de Tukey-Kramer de comparações múltiplas, $\mathrm{n}=5-8$ animais/grupo 
5.2.5 O tratamento terapêutico com CBD diminui a permeabilidade do endotélio vascular pulmonar

Com relação aos parâmetros relacionados ao processo inflamatório, investigamos, ainda, os efeitos do tratamento terapêutico com CBD sobre a permeabilidade vascular pela medida indireta da presença de proteínas (albumina) no LBA, 1 e 2 dias após a indução da inflamação. Para tanto, cinquenta e quatro camundongos foram separados ao acaso em 4 grupos (sal+veículo, LPS+ veículo, LPS + CBD 20, LPS+CBD 80) e avaliados 1 e 2 dias após a indução da inflamação. Brevemente, os animais foram anestesiados e receberam solução salina ou LPS por via intra-nasal. Decorridas $6 \mathrm{~h}$, os animais receberam uma dose de CBD ou veículo (i.p.). Para efeito de análise estatística, os dados de atividade de MPO foram analisados utilizando o teste de Kruskal-Wallis seguido do teste de Dunn de comparações múltiplas, após os valores terem sido normalizados como percentual do grupo controle não inflamado (Sal+ veículo).

\section{RESULTADOS:}

A tabela 21 mostra e a figura 22 ilustra que o tratamento terapêutico com CBD (80 mg/kg) diminuiu a concentração de proteína no LBA, 1 dia ( $K W=7,5 ; p<0,05)$ após a indução da inflamação. Quando analisamos os resultados da dose de 20 $\mathrm{mg} / \mathrm{kg}$ (1 dia) e das doses de 20 e $80 \mathrm{mg} / \mathrm{kg}$ (2 dias), após a indução da inflamação, observamos uma diminuição da concentração de proteínas no LBA que, no entanto, não foi estatisticamente significante. 
Tabela 21 - Efeito do tratamento terapêutico com o CBD sobre a concentração de proteína no LBA de camundongos submetidos ao modelo de ALI

Proteína no LBA (\% controle)

\begin{tabular}{c|cc}
\hline Grupos & $\mathbf{1}$ dia & 2 dias \\
\hline LPS + Veículo & $272 \pm 33$ & $155 \pm 13$ \\
\hline LPS + CBD 20 & $189 \pm 32$ & $117 \pm 11$ \\
\hline LPS + CBD 80 & $146 \pm 17 \boldsymbol{b}$ & $118 \pm 15$ \\
\hline
\end{tabular}

Os dados representam a média \pm erro padrão, correspondente à concentração de proteína no LBA. A letra $\boldsymbol{b}$ representa um $p<0,05$ quando comparado ao grupo LPS+veículo. Foi utilizado o teste estatístico Kruskal-Wallis seguido do teste de Dunn de comparações múltiplas, $n=4-9$ animais/grupo.

\section{Proteína no LBA}

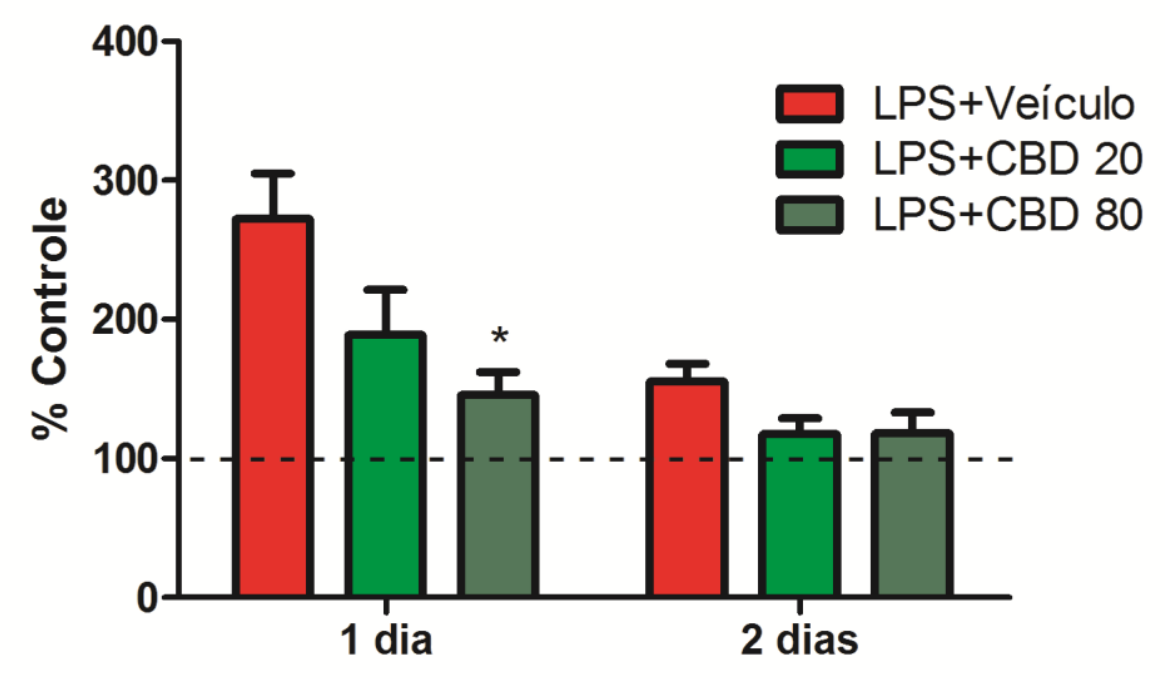

Figura 22 - Efeitos do tratamento terapêutico com CBD sobre a concentração de proteína no LBA de camundongos submetidos ao modelo murino de $\mathrm{ALI}, 1$ e 2 dias após a indução da inflamação. ${ }^{*} p<0,05$ quando comparados ao grupo LPS+veículo. Kruskal-Wallis seguido do teste de Dunn de comparações múltiplas, $n=4-9$ animais/grupo 
5.2.6 O tratamento terapêutico com CBD diminui a expressão de moléculas de adesão em neutrófilos do LBA

Por fim, resolvemos analisar os efeitos do tratamento terapêutico com CBD sobre um dos fatores mais importantes na migração de leucócitos, a expressão de moléculas de adesão. Desta forma, após avaliarmos todos os parâmetros relacionados ao processo inflamatório descritos anteriormente, decidimos avaliar a expressão de moléculas de adesão em neutrófilos do LBA. Para tanto, 30 camundongos foram separados ao acaso em 4 grupos (sal+veículo, LPS+veículo, LPS+CBD 20, LPS+CBD 80) e avaliados 1 dia após a indução da inflamação. Brevemente, os animais foram anestesiados e receberam solução salina ou LPS por via intra-nasal. Decorridas $6 \mathrm{~h}$, os animais receberam uma dose de CBD ou veículo (i.p.).

É importante ressaltar que nesta análise estatística não existe o grupo sal+veículo. Isto se deu, pois os animais deste grupo (não inflamado) não apresentam quantidade significante de neutrófilos, o que tornava impossível a obtenção da média de intesidade de fluorescência (MFI).

\section{RESULTADOS:}

A tabela 22 mostra e a figura 23 ilustra que o tratamento terapêutico com CBD $80 \mathrm{mg} / \mathrm{kg}$ diminuiu a expressão de ICAM-1 nos neutrófilos do LBA de animais submetidos ao modelo de ALI, 1 dia após a indução da inflamação. Observamos que o tratamento com CBD, em nenhuma das doses, foi capaz de alterar a expressão de VLA-4 nos neutrófilos. Analisamos, também, a expressão destas moléculas de adesão em linfócitos e macrófagos e não encontramos diferenças estatisticamente significantes entre os grupos (dados não mostrados). 
Tabela 22 - Efeito do tratamento terapêutico com o CBD sobre a expressão de moléculas de adesão em neutrófilos do LBA de camundongos submetidos ao modelo de ALI

Moléculas de adesão (MFI)

\begin{tabular}{c|cc}
\hline Grupos & VLA-4 & ICAM-1 \\
\hline LPS + Veículo & $13,4 \pm 0,1$ & $84 \pm 3,8$ \\
\hline LPS + CBD 20 & $13,2 \pm 0,6$ & $74 \pm 3,2$ \\
\hline LPS + CBD 80 & $13,5 \pm 0,3$ & $68 \pm 3,1 \boldsymbol{b}$ \\
\hline
\end{tabular}

Os dados representam a média \pm erro padrão, correspondente à média de intesidade de fluorescência de VLA-4 e ICAM-1 nos neutrófilos do LBA. A letra $\boldsymbol{b}$ representa um $p<0,05$ quando comparado ao grupo LPS+veículo. Foi utilizado o teste estatístico Kruskal-Wallis seguido do teste de Dunn de comparações múltiplas, $\mathrm{n}=4-10$ animais/grupo.

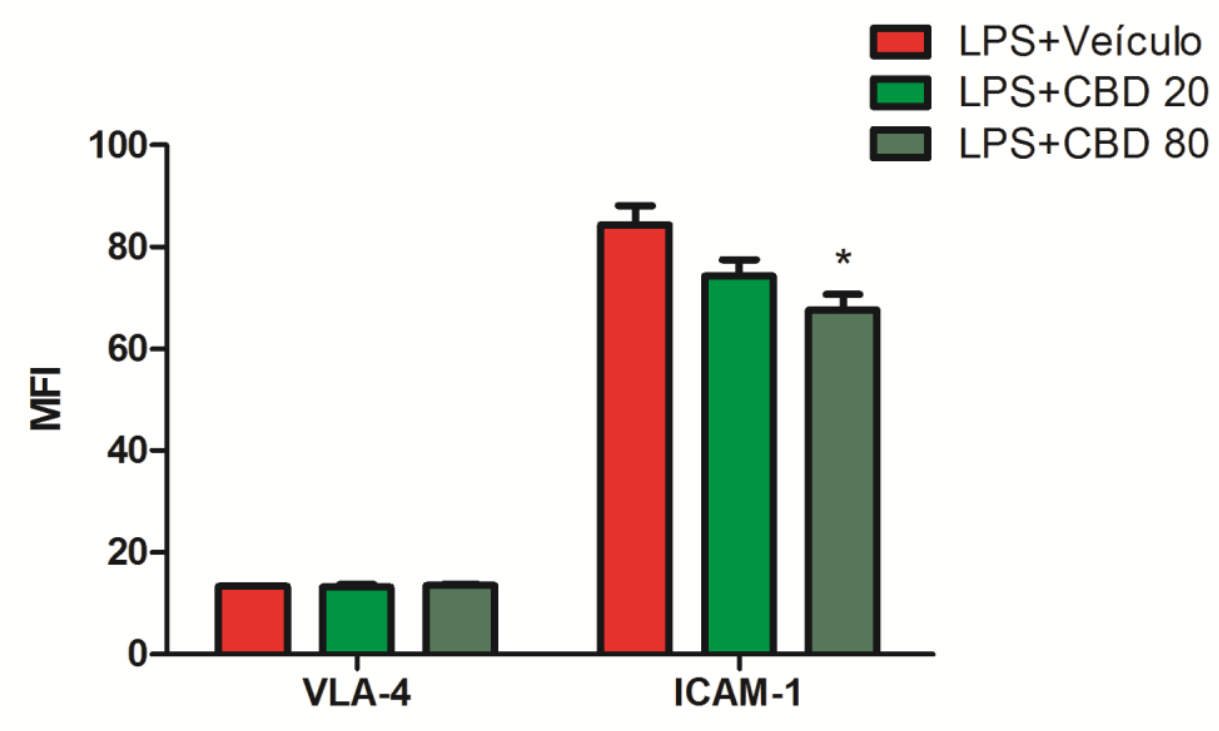

Figura 23 - Efeitos do tratamento terapêutico com CBD sobre a expressão de moléculas de adesão em neutrófilos do LBA de camundongos submetidos ao modelo murino de ALI, 1 dia após a indução da inflamação. * $p<0,05$ quando comparados ao grupo LPS+veículo. Kruskal-Wallis seguido do teste de Dunn de comparações múltiplas, $\mathrm{n}=$ 4-10 animais/grupo 


\section{DISCUSSÃO}

O CBD é considerado o maior componente não psicotrópico da marijuana (Cannabis sativa) (ZUARDI, 2008); mais especificamente, é tido como um fármaco que apresenta potentes propriedades imunossupressoras e anti-inflamatórias (MECHOULAM; PARKER; GALLILY, 2002). De fato, foram relatados para ele efeitos imunossupressores e anti-inflamatórios em modelos de diabetes mellitus tipo I e em complicações da diabetes, artrite reumatóide, injúria por isquemia/reperfusão, inflamação intestinal, hepatite autoimune e, dentre outros, esclerose múltipla (IZZO et al., 2009). No entanto, e tanto quanto seja de nosso conhecimento, até o presente momento não há dados na literatura relativos aos possíveis efeitos do CBD em modelos que envolvam inflamação e injúria pulmonar. Desta forma, pareceu-nos interessante avaliar os efeitos do CBD em um modelo de injúria pulmonar aguda conhecida como ALI (da sigla em inglês, Acute Lung Injury). Neste sentido, os tratamentos disponíveis até o momento para ALI constituem, infelizmente, medidas de suporte, uma vez que terapias específicas ainda não foram desenvolvidas para a mesma.

A ALI e, sua forma mais severa, a síndrome do desconforto respiratório agudo (ARDS), são doenças pulmonares de início agudo e caracterizadas por infiltrado pulmonar bilateral (GROMMES; SOEHNLEIN, 2011). A causa mais comum de ALI/ARDS em humanos é a sepsis, embora a seqüência exata desta relação não esteja ainda muito bem elucidada. Em especial, a ALI caracteriza-se por uma injúria alvéolo-capilar, inflamação com acúmulo de neutrófilos e produção de citocinas próinflamatórias (TSUSHIMA et al., 2009); pode resultar em falha respiratória persistente e dependência prolongada de ventilação mecânica, aumento de susceptibilidade à falência múltipla de órgãos e, consequentemente, de mortalidade (RUBENFELD et al., 2005).

ALI e ARDS são problemas relevantes de saúde pública. A elas têm sido atribuídas cerca de 200 mil hospitalizações e 75 mil mortes todos os anos nos Estados Unidos (quase $40 \%$ da mortalidade total) (RUBENFELD et al., 2005). No Brasil, existem poucas informações a respeito da incidência de ALI e de ARDS em Unidades de Terapia Intensiva (UTI). Em UTI's do Hospital das Clínicas de Porto 
Alegre mostrou-se em 1301 pacientes uma incidência de 2,3\% de ARDS e de 3,8\% de ALI (FIALKOW et al., 2002); no Hospital das Clínicas de Ribeirão Preto foi relatada uma incidência de $1 \%$ de $A L I$ e 2,2\% de ARDS em 597 pacientes (OLIVEIRA; BASILLE FILHO, 2006).

Nosso trabalho foi planejado e executado com a finalidade precípua de buscar por eventuais efeitos de um tratamento profilático com CBD, ou seja, de um tratamento realizado previamente à indução da inflamação e, também por efeitos decorrentes de um tratamento terapêutico, isto é, avaliando-se os efeitos do CBD $6 \mathrm{~h}$ após a indução da inflamação. O delineamento experimental utilizado no protocolo de tratamento terapêutico foi escolhido em função de dados obtidos em um experimento piloto; nele observa-se, 6 h após a indução da inflamação pulmonar, um aumento do número de leucócitos no LBA (dados não mostrados). É importante ressaltar, ainda, que neste trabalho, fez-se uma avaliação dos efeitos do CBD em animais submetidos ao modelo de ALI dentro de uma perspectiva neuroimune. Isto implica dizer que, em nosso trabalho, é importante a avaliação não apenas dos efeitos anti-inflamatório do CBD mas, também, da possível relação existente entre estes efeitos e as modificações centrais (comportamentais e endócrinas) decorrentes da ativação imune periférica assim como dos reflexos do tratamento com o CBD nesses efeitos.

De maneira geral, mostramos que o tratamento profilático com CBD foi capaz de produzir uma diminuição prolongada em diversos parâmetros de inflamação, tais como migração de leucócitos (neutrófilos, macrófagos e linfócitos) para os pulmões, atividade de MPO no tecido pulmonar, produção de citocinas e quimiocinas próinflamatórias no LBA e permeabilidade vascular, em um modelo murino de ALI induzida por LPS intra-nasal. Além disso, mostramos que o CBD alterou a distribuição de células $T$ regulatórias no sangue e no baço. Por fim, mostramos que a inflamação pulmonar induzida por LPS modificou poucos parâmetros comportamentais (diminuição da locomoção e da velocidade média dos camundongos no campo aberto), que foi revertida pelo tratamento com o CBD, e não ativou o eixo HPA. Neste contexto, mostramos ainda que a sinalização pelo receptor de adenosina A2A é, provavelmente, o mecanismo responsável pelos efeitos antiinflamatórios observados, uma vez que o uso de um antagonista deste receptor aboliu os efeitos anti-inflamatórios induzidos pelo CBD. 
Quando utilizamos o protocolo de tratamento terapêutico mostramos, de forma semelhante, que o CBD diminuiu de forma prolongada a migração de leucócitos (neutrófilos, macrófagos e linfócitos) para os pulmões, a atividade de MPO no tecido pulmonar, a produção de citocinas e quimiocinas pró-inflamatórias no LBA, e a permeabilidade vascular, 1 e 2 dias após a indução da inflamação pulmonar. Observamos, ainda, que o tratamento terapêutico com CBD diminuiu a expressão de moléculas de adesão em neutrófilos do LBA, no $1^{\circ}$ dia após a indução da inflamação.

Análise do protocolo experimental usado mostra que cuidou-se, inicialmente, de construir uma curva dose-resposta $(0,3$ a $80 \mathrm{mg} / \mathrm{kg})$ para analisar os efeitos do CBD em animais submetidos ao modelo de ALI induzido por LPS; avaliamos, neste sentido, a contagem total de leucócitos e a concentração de TNF no LBA, dois parâmetros gerais tidos como sendo indicativos de inflamação pulmonar, 1 dia após a indução da inflamação experimental. Mostramos que o CBD, nas doses de 20, 30 e $80 \mathrm{mg} / \mathrm{kg}$, diminuiu a migração de leucócitos para os pulmões. Adicionalmente, mostramos que o CBD nas doses de 10, 20, 30 e $80 \mathrm{mg} / \mathrm{kg}$ diminuiu a produção de TNF no sobrenadante do LBA. Esses resultados indicam a existência de uma relação entre as doses de CBD e o efeito que produziram em dois relevantes parâmetros da inflamação pulmonar induzida por LPS. É interessante observar que o tratamento com CBD na dose de $40 \mathrm{mg} / \mathrm{kg}$ não produziu resultados estatisticamente diferentes daqueles observados no grupo veicúlo+LPS (controle inflamado) e que o efeito do tratamento com CBD na dose de $30 \mathrm{mg} / \mathrm{kg}$ foi menos pronunciado que aquele obtido após as doses de 20 e $80 \mathrm{mg} / \mathrm{kg}$. Esses resultados sugerem que os efeitos do CBD sobre o processo pulmonar tenham se expressado na forma de uma curva em $U$ invertido, também conhecida como curva em formato de sino. Curiosamente, este tipo de curva ou de relação é característica dos canabinóides, sejam eles derivados da Cannabis sativa, sintéticos ou aqueles que alteram a degração de endocanabinóides (VIVEROS; MARCO; FILE, 2005; RIBEIRO et al., 2009). No presente trabalho, a curva obtida foi relativamente discreta; mas foi suficiente para mostrar o cuidado que se deve ter quando da escolha da dose a ser ensaiada em experimentos que empreguem canabinóides. Este fato é experimental e clinicamente importante, uma vez que erros na escolha da dose a ser ensaiada podem levar à não observação do efeito terapêutico desejado ou, até mesmo, à 
piora dos sintomas dos pacientes tratados (IZZO et al., 2009). Desta forma, este primeiro experimento foi realizado para selecionar as doses a serem empregadas no trabalho que, em nosso caso, foram de 20 e $80 \mathrm{mg} / \mathrm{kg}$. Mais especificamente, a dose de $20 \mathrm{mg} / \mathrm{kg}$ foi usada nos experimentos que envolveram tratamento profilático dos animais com CBD. As doses de 20 e $80 \mathrm{mg} / \mathrm{kg}$ de CBD foram empregadas nos experimentos em que os animais receberam tratamento terapêutico.

Quando do início dos estudos para avaliação dos efeitos do CBD no modelo de ALI, pareceu-nos importante analisar, em um primeiro momento, o influxo de leucócitos para os pulmões. A migração de neutrófilos para o interstício e para o espaço broncoalveolar é importante por exercer papel central na progressão da ALI induzida por LPS (GROMMES; SOEHNLEIN, 2011). Observamos que o CBD na dose de $20 \mathrm{mg} / \mathrm{kg}$ usada profilaticamente reduziu consideravelmente a migração de leucócitos para os pulmões dos camundongos 1, 2 e 4 dias após a indução da ALI, como demonstrado pela contagem total de leucócitos no LBA. A contagem diferencial de leucócitos revelou que os neutrófilos estavam bastante diminuídos, assim como os macrófagos e os linfócitos, 1, 2 e 4 dias após a indução da inflamação nos animais tratados profilaticamente com CBD. Sete dias após a indução da inflamação os animais tratados com CBD já haviam se recuperado por completo, momento em que aqueles tratados com veículo ainda apresentavam um pequeno e não significante aumento no número total de leucócitos. No entanto, neste $7^{\circ}$ dia evidenciamos um aumento significante na contagem diferencial de neutrófilos nos animais do grupo controle, aumento este que foi diminuído pelo tratamento com CBD.

Sabe-se ser a migração de leucócitos para o sítio da inflamação extremamente importante para o dano e para a resolução da lesão tecidual (GROMMES; SOEHNLEIN, 2011). Assim o CBD, por diminuir a migração de neutrófilos, parece ter potencial para diminuir a inflamação no modelo de ALI induzida por LPS. Desta maneira, em decorrência da presença de um menor acúmulo de neutrófilos nos pulmões de camundongos tratados com CBD, pareceu-nos relevante investigar outros parâmetros que pudessem melhor caracterizar não só os efeitos do CBD na migração de leucócitos para o pulmão, mas também os efeitos anti-inflamatórios deste fármaco em nosso modelo.

Importante ressaltar, neste momento, que a migração de neutrófilos para os pulmões de per se não é suficiente para causar a ALI; de fato, os neutrófilos podem 
migrar para os pulmões e não causar inflamação, o que implica ser necessária uma ativação dos mesmos (GROMMES; SOEHNLEIN, 2011), isto é, implica na necessidade de produção e liberação de citocinas e quimiocinas. Assim, pareceunos importante analisar a produção de citocinas e quimiocinas pró-inflamatórias durante a progressão da doença em animais submetidos ao modelo de ALI tratados ou não com CBD.

Mostramos a ocorrência de uma diminuição nas concentrações de TNF e de IL6 em camundongos tratados profilaticamente com CBD, 1 e 2 dias após a indução da ALI. Estes resultados são extremamente importantes: estas citocinas são ambas essenciais para o estabelecimento dos processos inflamatórios e para a ativação de fagócitos. Corroborando com nossos achados, mostrou-se que a inibição da enzima conversora de TNF reduziu parâmetros inflamatórios da ALI induzida por LPS em ratos (SHIMIZU et al., 2009). Mostramos, ainda, que o tratamento profilático com CBD diminuiu a produção de MIP-2 (CXCL2), 1 e 2 dias após a indução da ALI, assim como a produção de MCP-1 (CCL2), 2 dias após a indução da mesma. Estes resultados parecem explicar a dinâmica da migração de leucócitos para os pulmões, sendo as quimiocinas as responsáveis pela movimento dos leucócitos para o foco inflamatório (KOBAYASHI, 2008). Desta forma, parece-nos razoável sugerir que o CBD, por diminuir a produção de MIP-2 no LBA, reduziria a migração de neutrófilos para os pulmões. Apoiando nossos achados, mostrou-se que o bloqueio (ZARBOCK; ALLEGRETTI; LEY, 2008) ou a depleção do gene (REUTERSHAN et al., 2006) do receptor de MIP-2 (CXCR2) atenuaram tanto a migração neutrofílica como a inflamação em modelos de ALI. Neste sentido, a concentração de MCP-1 no LBA poderia explicar a redução do número de neutrófilos, de macrógafos e de linfócitos observada no presente estudo quando da análise diferencial do LBA. Recentemente, mostrou-se que a depleção do gene do MCP-1 reduziu o influxo de neutrófilos e o clearance bacteriano em pulmões de camundongos infectados por $E$. coli (BALAMAYOORAN et al., 2011). Em seu conjunto, esses resultados sugerem que 0 MCP-1 medeie, também, a quimiotaxia de neutrófilos corroborando igualmente para os presentes achados. Desta forma, quer nos parecer sejam os achados deste trabalho importantes por sugerir que o CBD tenha modificado o milieu de citocinas e quimiocinas no pulmão de camundongos submetidos ao modelos de ALI.

Os neutrófilos são altamente especializados para a função primária de fagocitose e destruição de microrganismos (KLEBANOFF, 2005). A mieloperoxidase 
(MPO) é, entre outras, uma molécula com atividade microbicida liberada dentro dos fagossomos durante o processo de desgranulação. Sabe-se ser o ácido hipocloroso $(\mathrm{HOCl})$ o produto inicial do sistema $\mathrm{MPO}-\mathrm{H}_{2} \mathrm{O}_{2}$-cloridrato que inclui, ainda, a produção de outros produtos (KLEBANOFF, 2005). Neste sentido, o $\mathrm{HOCl}$ é o composto oxidante com atividade bactericida principal produzido pelos neutrófilos. Assim, uma análise da atividade da MPO tem sido considerada um bom marcador para a atividade de neutrófilos nos tecidos, principalmente quando da presença de doenças. Mostramos que a atividade da MPO estava reduzida nos camundongos tratados profilaticamente com o CBD e submetidos à inflamação pulmonar, 1, 2 e 4 dias após a indução da ALI. Neste contexto, é importante ressaltar que o MIP-2 promove não somente a migração de neutrófilos , mas também o aumento na atividade de MPO (KOBAYASHI, 2008). Desta forma, parece-nos razoável sugerir que o CBD, por reduzir a produção de MIP-2 no LBA, tenha diminuído a atividade da MPO nos pulmões. Entendemos que esta diminuição de atividade de MPO deva ter ocorrido em função de uma menor produção dos mediadores inflamatórios analisados. Quer nos parecer seja este efeito importante porque essa diminuição de atividade levaria a uma redução da capacidade da MPO em causar dano tecidual. Em decorrência, quanto menor o dano tecidual, menor a capacidade dos leucócitos em gerar o milieu inflamatório nos pulmões.

É de conhecimento geral que o processo inflamatório se inicia na microcirculação, sendo caracterizado pela formação de espaços intercelulares responsáveis pelo aumento da permeabilidade microvascular observada na doença (WARE, 2006). Desta forma, a diminuição na função da barreira celular epitelial facita o influxo de fluido rico em proteínas e outras macromoléculas para o espaço alveolar. Em nosso trabalho, mostramos que o tratamento profilático com CBD diminuiu a concentração de proteínas no LBA de animais submetidos ao modelo de ALI. Sabe-se ser a quantificação de albumina no LBA uma medida indireta da permeabilidade vascular de animais submetidos a modelos de inflamação pulmonar. Assim, pode-se dizer que o CBD usado de forma profilática tenha sido capaz de reduzir a permeabilidade vascular de camundongos submetidos ao modelo experimental de $A L I$, fato que indica a capacidade que ele apresenta de inibir os eventos iniciais de uma inflamação. Esta ação do CBD é extremamente importante uma vez que o aumento de um fluido rico em proteínas no espaço alveolar tem 
potencial para ativar os macrófagos alveolares (GROMMES; SOEHNLEIN, 2011) e, assim, iniciar um processo inflamatório.

Uma característica importante de nossos achados relacionados ao protocolo profilático, foi o fato de ter sido o tratamento com dose única de CBD $(20 \mathrm{mg} / \mathrm{kg})$ capaz de diminuir de forma prolongada a inflamação, principalmente no $1^{\circ}$ e $2^{\circ}$ dia após sua indução. Um dos fatores que poderiam contribuir para este efeito é o tempo de meia-vida do CBD. Mostrou-se, neste sentido que o CBD, como molécula lipossolúvel, tem meia vida plasmática de $24 \pm 6$ horas, após administração intravenosa de uma dose de $20 \mathrm{mg} / \mathrm{kg}$ em humanos (OHLSSON et al., 1986). Em cães, o CBD foi rapidamente distribuído pelos tecidos, tendo-se observado uma eliminação prolongada e uma meia-vida de aproximadamente 9 horas (SAMARA; BIALER; MECHOULAM, 1988). Os trabalhos de Ohlsson et al. (1986) e de Samara, Bialer e Mechoulam (1988) mostraram que o CBD tem um grande volume de distribuição. Neste sentido, a característica de lipossolubilidade do CBD pode fazer com que ele se deposite no tecido adiposo, o que certamente prolonga seus efeitos biológicos. Embora não se tenha achado, na literatura, dados relativos à cinética do CBD em roedores, parece ser possível inferir a existência de uma relação direta entre a biodisponibilidade do CBD e seus efeitos anti-inflamatórios.

Outro fator que parece ter contribuído de forma relevante para os efeitos antiinflamatórios prolongados do CBD em nosso trabalho foi a característica do protocolo experimental utilizado, de per se. O tratamento com o CBD feito previamente à indução da inflamação, teria gerado um ambiente pulmonar antiinflamatório que, por sua vez, reduziria o processo inflamatório desde sua origem levando assim e, ao longo do tempo, à produção de uma menor inflamação. De qualquer forma, acreditamos que tanto a meia-vida como o protocolo experimental utilizado tenham sido sozinhos ou, muito provavelmente juntos, os responsáveis pelos interessantes efeitos observados neste trabalho.

Neste momento, pareceu-nos importante analisar os mecanismos através dos quais o CBD exerceria seus efeitos anti-inflamatórios no modelo de ALI induzido por LPS. O CBD é reconhecido como tendo uma miríade de mecanismos de ação, conforme revisado detalhadamente por Zuardi (2008) e Izzo et al. (2009). Dentre eles, cabe destacar a capacidade que o CDB tem de inibir a captação de adenosina, pela inibição competitiva de um transportador equilibrativo de adenosina; isto é, a sinalização via receptor de adenosina A2A parece ser um dos principais 
mecanismos responsáveis pelas ações anti-inflamatórias do CBD (CARRIER; AUCHAMPACH; HILLARD, 2006). Carrier et al. (2006) mostraram que o tratamento com uma dose baixa de CBD (1 mg/kg) diminuiu substancialmente a produção de TNF em animais tratados com LPS. Mostraram, ainda, que o tratamento com ZM241385, um antagonista altamente seletivo do receptor de adenosina $A 2 A$, foi capaz de prevenir a redução induzida pelo CBD na produção de TNF, assim como o fez, também, a depleção genética deste receptor. Desta forma, sabendo da importância do TNF e de outros mediadores pró-inflamatórios em insultos infecciosos e inflamatórios, decidimos empregar como ferramenta de estudo o ZM241385, o mesmo antagonista do receptor A2A usado por Carrier et al. (2006) para melhor caracterizar o mecanismo anti-inflamatório do CBD em nosso modelo.

Notavelmente, o tratamento com ZM241385 previniu todos os efeitos antiinflamatórios do CBD, em todos os períodos de tempo analisados neste trabalho. Especificamente, observamos que o pré-tratamento com ZM241385 preveniu a diminuição induzida pelo CBD na migração de leucócitos para os pulmões, e na atividade de MPO avaliada no tecido pulmonar; concomitantemente, preveniu a diminuição da produção de citocinas (TNF e IL-6) e das quimiocinas (MCP-1 e MIP2) no LBA. Por fim, observamos que o tratamento com ZM241385 preveniu a diminuição da permeabilidade vascular, medida pela concentração de albumina no LBA. Todos esses dados foram observados nos mesmos períodos de tempo analisados anteriormente, isto é, 1, 2, 4 e 7 dias após a indução da inflamação.

Assim, e tomados em seu conjunto, nossos achados sugerem fortemente 0 envolvimento do aumento da oferta de adenosina extracelular com os efeitos agora discutidos para CBD. Em conseqüência, quer nos parecer seja possível sugerir que o aumento da sinalização via receptor de adenosina A2A seja o mecanismo responsável pelos efeitos anti-inflamatórios observados nesse trabalho que empregou o modelo de ALI induzida por LPS.

Outro fator importante que merece ser mencionado é o envolvimento da sinalização via receptores de adenosina como um mecanismo fisiológico regulador na ALI. De fato, alguns trabalhos recentes de literatura mostraram um papel da adenosina na atenuação da inflamação em modelos de ALI (REUTERSHAN et al., 2007; NGAMSRI et al., 2010; SCHINGNITZ et al., 2010; WAGNER et al., 2010). Mostrou-se, em especial, que a sinalização via receptor $A 2 A$ e $A 2 B$ tem um papel relevante na resolução da ALI induzida por LPS (ECKLE; KOEPPEN; ELTZSCHIG, 
2009). Mais recentemente mostrou-se, na ALI induzida por LPS, que ativação do receptor de adenosina $\mathrm{A} 2 \mathrm{~A}$, pelo uso de um agonista diminuiu a migração de neutrófilos para os pulmões, produzindo uma menor concentração de citocinas e de quimiocinas pró-inflamatórias, induzindo, ainda, uma redução da permeabilidade vascular, dentre outros efeitos relatados (REUTERSHAN et al., 2007; IMPELLIZZERI et al., 2011).

Desta forma, tomados em conjunto os dados de literatura e os presentes achados após emprego do antagonista de receptor A2A (ZM241385), parece-nos possível dizer que o aumento da oferta de adenosina extracelular via sinalização do receptor de adenosina A2A acima sugerido tenha sido, de fato, o mecanismo responsável pelos efeitos anti-inflamatórios do tratamento profilático com CBD no modelo de ALI induzido por LPS.

Quer nos parecer, no entanto, seja relevante ressaltar mais uma vez que o perfil farmacológico do CBD é muito complexo; desta forma, não se pode descartar a presença de outros mecanismos de ação na explicação dos efeitos anti-inflamatórios agora relatados para o CBD. Mostrou-se, em especial, que o CBD aumenta a oferta extracelular de anandamida por inibir a FAAH (Fatty Acid Amide Hydrolase); esse aumento de anandamida produziria seus efeitos via receptores $\mathrm{CB} 1$, mecanismo ao qual já se atribuíram efeitos anti-inflamatórios para o CBD em modelos de inflamação intestinal (CAPASSO et al., 2008; ALHAMORUNI et al., 2011). Recentemente, mostrou-se que as ativações de receptores vanilóides tipo 3 (TRPV3) (DE PETROCELLIS et al., 2011) e PPAR- $\gamma$ (Peroxisome ProliferatorActivated Receptor) (DE FILIPPIS et al., 2011) constituíram mecanismos importantes para o entendimento dos efeitos do CBD na resolução de doenças inflamatórias intestinais. Mais recentemente, mostrou-se que o CBD ativa os receptores vanilóides tipo 1 (TRPV1) atenuando, desta forma, os sinais e sintomas inflamatórios presentes em um modelo de hepatite autoimune (HEGDE; NAGARKATTI; NAGARKATTI, 2011). Neste sentido, já se relatou, também, que o CBD seja um agonista inverso de receptores CB2, uma ação entendida como capaz de contribuir para seus efeitos anti-inflamatórias (THOMAS et al., 2007). Outra hipótese, advinda de estudos relacionados à atividade antitumoral do CBD, postula que seus efeitos sejam decorrência de uma redução na atividade de 5-lipoxigenase (5-LOX) (MASSI et al., 2008); de fato, um efeito como este também contribuiria para os efeitos antiinflamatórios deste fármaco. 
Parece-nos seja ainda relevante destacar dados advindos do emprego de um modelo de hipóxia-isquemia cerebral in vitro; mostrou-se neste modelo que o CBD diminuiu não apenas as concentrações de mediadores pró-inflamatórios como cicloxigenase-2 (COX-2) e óxido nítrico sintase induzível (iNOS), assim como também aquelas de TNF e IL-6 (CASTILLO et al., 2010) estando os receptores de adenosina $\mathrm{A} 2 \mathrm{~A}$ e, em menor extensão, aqueles para CB2 envolvidos nestes efeitos (CASTILLO et al., 2010). Por fim, mostrou-se que o CBD tem efeito anti-inflamatório em modelos de retinopatia diabética (EL-REMESSY et al., 2003; EL-REMESSY et al., 2008), sendo este efeito considerado uma decorrência da ativação de receptores para adenosina A2A (LIOU et al., 2008).

Por tudo quanto exposto e discutido acima compreende-se que diversos mecanismos de ação possam ser responsáveis pelos efeitos anti-inflamatórios do CBD apresentados neste trabalho. É importante destacar que essa diversidade de mecanismos advém de modelos distintos de doenças, analisadas em diversos órgãos. Desta forma, acreditamos que os efeitos anti-inflamatórios do CBD dependam de mecanismos fisiológicos locais que controlam a inflamação; de fato, pelo que foi exposto percebe-se que o CBD não somente atua diretamente em uma variedade de receptores como, também, aumenta, diminui, ativa ou inibe mecanismos locais importantes e responsáveis pela gênese ou controle das doenças inflamatórias. Quer nos parecer assim, que os efeitos anti-inflamatórios do CBD sejam órgão-específicos, isto é, seriam dependentes de mecanismos locais de resolução da inflamação. Obviamente, devido ao amplo espectro de ações farmacológicas do CBD, torna-se impossível responsabilizar um único mecanismo de ação como sendo responsável pelos efeitos anti-inflamatórios deste fármaco.

Após análise dos efeitos do CBD em diversos parâmetros de inflamação, pensamos fosse interessante avaliar possíveis efeitos do mesmo sobre a imunidade adquirida. De fato, as células T regulatórias (Treg), como sua própria denominação indica, são reguladoras das respostas imunes inata ou adquirida. Dados relativamente recentes de literatura apontam para um papel importante das células Treg na resolução do modelo de ALI induzido por LPS (D'ALESSIO et al., 2009). Demonstrou-se um aumento dessas células no LBA de animais submetidos ao modelo de ALI concomitante à sua recuperação e, ainda, que na ausência de células T (utilizando animais Rag-1 -/-) tornou-se difícil para o organismo lidar com a doença (D'ALESSIO et al., 2009). Apesar de não termos conseguido mostrar a dinâmica das 
células Treg em nosso modelo (analisando o percentual de células Treg nos dias 1, 2, 4 e 7 após a indução da inflamação), observamos ocorrência de uma modificação na distribuição dessas células no baço e no sangue dos animais tratados com CBD, 1 e 2 dias após a indução da ALI. Esses resultados, por nós considerados preliminares, parecem indicar que o CBD, de alguma maneira, tenha alterado a distribuição e, talvez, a atividade das células Treg. Se assim o for, estudos adicionais devem ser realizados para melhor caracterizar os efeitos do CBD na imunidade regulatória.

Um dos objetivos do nosso trabalho era caracterizar os possíveis efeitos neuro-endócrinos oriundos da inflamação pulmonar. De fato, é amplamente conhecido 0 fato de que a ativação imune periférica gera alterações comportamentais (comportamento doentio) e ativação do eixo HPA. Desta forma, avaliamos possíveis efeitos comportamentais decorrentes do modelo de inflamação pulmonar, observando os animais no campo aberto. Em especial, analisamos a distância percorrida, o tempo gasto por eles nas zonas periférica e central e a velocidade média dos mesmos no aparato, 6 h e 24 h após a indução da inflamação pulmonar. É importante ressaltar que a avaliação comportamental dos animais foi realizada, neste trabalho, em uma sala fracamente iluminada e sem ruídos, e que os dados foram adquiridos por meio de uma câmera de vídeo instalada no teto da sala. Desta forma, a presença do observador não interferiu com a manifestação do comportamento dos animais.

Curiosamente, observamos que $6 \mathrm{~h}$ após a indução da inflamação não foi possível detectar qualquer efeito comportamental dela decorrente, isto é, não observamos diferenças estatísticas entre dados de grupos controle e experimental. No entanto, a análise estatística revelou que o tratamento com CBD per se foi capaz de aumentar a distância movida na arena e o tempo gasto na zona central do aparato. Estes resultados sugerem uma diminuição dos níveis de ansiedade dos animais no campo aberto (RIBEIRO et al., 2009). Nossos dados, então, corroborariam outros de literatura que mostraram um efeito ansiolítico para o CBD em diversos modelos de ansiedade (GUIMARAES et al., 1990; BITENCOURT; PAMPLONA; TAKAHASHI, 2008; CAMPOS; GUIMARAES, 2008; GOMES; RESSTEL; GUIMARAES, 2011). 
Quando avaliamos o comportamento dos animais $24 \mathrm{~h}$ após a indução da inflamação observamos que os animais inflamados e não tratados profilaticamente com CBD, apresentam uma leve diminuição na distância movida, na velocidade média na arena e no tempo gasto na zona central do aparato. Esses dados, ainda que sutis, sugerem o aparecimento de comportamento doentio nos animais. Análise estatística adicional mostrou que o tratamento profilático com CBD reverteu apenas a diminuição da distância movida e da velocidade média dos animais na arena. Desta forma, quer nos parecer seja possível afirmar que $24 \mathrm{~h}$ após a indução da inflamação os animais apresentam sinais sutís de comportamento doentio, tendo sido o tratamento profilático com CBD capaz de revertê-lo.

Analisamos, ainda, eventual ativação do eixo HPA, medindo os níveis de corticosterona no soro dos animais 6 e 24 h após a indução da inflamação pulmonar. A análise estatística revelou que nem a inflamação ou o tratamento profilático com CBD foram capazes de alterar os níveis de corticosterona sérica dos animais. Esses dados, juntamente com aqueles de comportamento, sugerem que a inflamação pulmonar induzida pela administração intra-nasal de LPS, em nosso caso, tenha um efeito bastante localizado e que, desta forma, não haveria ativação do sistema neuro-endócrino. Embora não estejam conectados intimamente, a falta de resultados na análise da celularidade na medula óssea e no hemograma dos animais corroboraria com o efeito sistêmico pouco significativo induzido pela inflamação pulmonar em nosso modelo experimental.

Uma vez realizada a análise crítica dos resultados obtidos após o emprego profilático do CBD avaliemos de idêntica forma, aqueles decorrentes de seu emprego terapêutico, isto é, do uso do CBD quando os animais já apresentavam os sinais de inflamação induzida. Ressaltamos, mais uma vez, que optamos por fazer estes experimentos por acreditar que nenhum paciente internado em UTI, por apresentar quadro de ALI/ARDS, receberia qualquer tipo de terapia à priori.

Desta forma, iniciamos nossos experimentos avaliando dados relativos à migração de leucócitos para o pulmão. Observamos que o tratamento terapêutico com CBD, nas duas doses analisadas (20 e $80 \mathrm{mg} / \mathrm{kg}$ ), foi capaz de diminuir substancialmente a contagem total de leucócitos no LBA no $1^{\circ}$ e no $2^{\circ}$ dia após a indução da inflamação. Mais especificamente, quando procedemos a contagem diferencial de leucócitos, observamos uma diminuição substancial do número de 
neutrófilos, macrófagos e linfócitos no LBA dos animais tratados com as duas doses de CDB e nos dois dias analisados. Estes dados coincidem com aqueles por nós observados quando do tratamento profilático.

Posteriormente, avaliamos a atividade de MPO no tecido pulmonar dos animais submetidos à inflamação pulmonar; observamos que o tratamento com CBD na dose de $80 \mathrm{mg} / \mathrm{kg}$ diminuiu de forma significante a atividade de MPO, 1 e 2 dias após a indução da inflamação. É importante ressaltar que o CBD na dose de $20 \mathrm{mg} / \mathrm{kg}$ também diminuiu a atividade de MPO; no entanto, a redução por ele induzida não foi estatisticamente significante. Observamos, ainda, que o tratamento com CBD nas doses de 20 e 80 mg/kg diminuiu a produção de TNF, IL6, MCP-1 e MIP-2 no LBA, 1 e 2 dias após a indução da inflamação. Mostramos, ainda, que o tratamento com CBD na dose de $80 \mathrm{mg} / \mathrm{kg}$ diminuiu a concentração de albumina no LBA no 1ำ dia após a indução da inflamação. Por fim, observamos que o tratamento com CBD na dose de $80 \mathrm{mg} / \mathrm{kg}$ diminuiu a expressão de ICAM-1 nos leucócitos do LBA, 1 dia após a indução da inflamação.

Tomados em conjunto, os presentes achados experimentais mostram que 0 tratamento terapêutico com CBD diminuiu a inflamação induzida por LPS intra-nasal. Estes resultados, exceto aqueles relativos à análise das moléculas de adesão, coincidem ou estão na mesma direção daqueles obtidos após emprego profilático do CBD. Desta forma, acreditamos que a discussão realizada anteriormente (a respeito dos efeitos decorrentes do tratamento profilático com CBD) se aplique perfeita e adequadamente aos dados agora obtidos após emprego terapêutico do fármaco, em especial aqueles relativos à migração de leucócitos para o pulmão, à atividade de MPO no tecido pulmonar, à produção de citocinas e quimiocinas no LBA, e à permeabilidade vascular. Assim sendo, acreditamos que o mecanismo de ação responsável pelos efeitos terapêuticos do CBD também decorra de uma sinalização via receptores de adenosina $\mathrm{A} 2 \mathrm{~A}$, isto é, seriam consequentes a um aumento das concentrações de adenosina extracelular, oriundas da inibição da captação de adenosina induzida pelo CBD. No entanto, ainda se faz necessária uma discussão adequada para os efeitos do CBD sobre a expressão de moléculas de adesão.

As moléculas de adesão, sejam elas as selectinas ( $E, P$ e $L$ ), as integrinas (VLA-4, LFA-1) ou aquelas da superfamília das imunoglobulinas (ICAM-1, VCAM-1), são extremamente importantes para os processos de rolamento, adesão e migração de células para o foco inflamatório. Mostramos neste trabalho uma menor expressão 
de ICAM-1 (CD54) nos neutrófilos presentes no LBA dos animais submetidos ao modelo experimental de ALI e tratados terapeuticamente com o CBD. Neste sentido, não constatamos diferenças quando analisamos a expressão de VLA-4 nos neutrófilos presentes no LBA. Embora não tenhamos examinado a expressão de ICAM-1 no protocolo de tratamento profilático, é razoável supor que a inibição de moléculas de adesão também estejam envolvidas com os efeitos anti-inflamatórios do CBD usado profilaticamente.

Sabe-se ser a ICAM-1 uma molécula relevante para a transmigração vascular de neutrófilos, macrófagos e linfócitos para os focos inflamatórios. De fato, dados de literatura mostram que a interação de CD11/CD18- 32 (LFA-1) com ICAM-1 é um evento crítico para a adesão e migração de neutrófilos através da barreira vascular endotelial pulmonar (XU et al., 2000). Já foi relatado, neste sentido, que o bloqueio de integrinas- $\beta 2$ em um modelo de ALI induzido por Escherichia coli protegeu os animais da infecção (XU et al., 2000). Estes dados sugerem que mudanças na expressão dessas moléculas, podem ser importantes para a redução na marginação e migração de células para o sítio inflamatório. Desta forma, quer nos parecer seja possível afirmar que a inibição da expressão de moléculas de adesão seja um fator importante para a manifestação dos efeitos anti-inflamatórios do CBD usado terapeuticamente em nosso modelo de ALI induzida por LPS e quiçá, até mesmo quando feito de forma profilática.

No contexto dessa discussão, acreditamos ser importante ressaltar mais uma vez que estudos estão sendo feitos em diferentes laboratórios para melhor entender os mecanismos moleculares através dos quais atua o CBD. Assim, já se demonstrou que o CBD diminuiu a produção e a liberação de citocinas pró-inflamatórias, tais como IL-1 $\beta$ e IL-6 em cultura celular de microglia ativada por LPS e, também, que

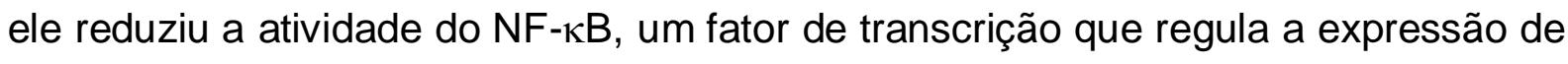
citocinas pró-inflamatórias (KOZELA et al., 2010). O CBD diminuiu, ainda, a ativação do fator de transcrição STAT1, um importante regulador de processos próinflamatórios dependentes de IFN $\beta$. Além disso, mostrou-se que o CBD aumenta a ativação do fator de transcrição STAT3, um mecanismo contra-regulatório que induz efeitos anti-inflamatórios. Por fim, e de relevância, mostrou-se não ser a inibição de citocinas pró-inflamatórias induzidas pelo CBD mediada por receptores canabinóides CB1 ou CB2 (KOZELA et al., 2010). 
Concluindo, parece-nos possível dizer que o uso profilático e terapêutico do CBD seja capaz de diminuir a inflamação pulmonar aguda induzida pela instilação intra-nasal de LPS, muito provavelmente em decorrência de um aumento da ativação dos receptores de adenosina A2A produzida pela inibição competitiva do transportador de adenosina pelo CBD. Embora se tenha consciência de que se deva ter cuidado com extrapolações de dados experimentais para o contexto clínico humano, quer nos parecer seja lícito sugerir que o CBD venha a ser considerado uma ferramenta terapêutica útil no tratamento de doenças inflamatórias pulmonares como a ALI e ARDS. 


\section{CONCLUSÕES}

\subsection{Conclusões específicas}

O protocolo de tratamento profilático realizado com CBD em animais submetidos ao modelo de inflamação pulmonar aguda (ALI) induzida pela administração intra-nasal de LPS:

$\checkmark \quad$ diminuiu de forma dose-dependente a migração de leucócitos totais para os pulmões e a produção de TNF no sobrenadante do LBA;

$\checkmark$ diminuiu a migração de leucócitos para os pulmões, especialmente de neutrófilos, macrófagos e linfócitos;

$\checkmark \quad$ não alterou a distribuição de leucócitos no sangue e na medula óssea;

$\checkmark \quad$ diminuiu a atividade de MPO, uma medida indireta da atividade de neutrófilos no tecido pulmonar;

$\checkmark \quad$ diminuiu a produção de citocinas (TNF e IL-6) e de quimiocinas (MCP-1 e MIP-2) no sobrenadante do LBA;

$\checkmark$ diminuiu a permeabilidade vascular, inferida pela medida das concentrações de albumina no sobrenadante do LBA;

$\checkmark \quad$ alterou a distribuição de células T regulatórias no sangue e no baço;

$\checkmark \quad$ apresentou poucos efeitos comportamentais no campo aberto;

$\checkmark \quad$ não alterou os níveis séricos de corticosterona;

Estes efeitos do $\mathrm{CBD}$, especialmente aqueles ligados aos parâmetros de inflamação, foram abolidos pelo uso de um antagonista dos receptores de adenosina A2A. 
O protocolo que empregou tratamento terapêutico com CBD em animais submetidos ao modelo de inflamação pulmonar aguda (ALI) induzida pela administração intra-nasal de LPS, por sua vez:

$\checkmark \quad$ diminuiu a migração de leucócitos para os pulmões, especialmente de neutrófilos, macrófagos e linfócitos;

$\checkmark \quad$ não alterou a distribuição de leucócitos no sangue e na medula óssea;

$\checkmark$ diminuiu a atividade de MPO, uma medida indireta da atividade de neutrófilos no tecido pulmonar;

$\checkmark \quad$ diminuiu a produção de citocinas (TNF e IL-6) e de quimiocinas (MCP-1 e MIP-2) no sobrenadante do LBA;

$\checkmark \quad$ diminuiu a permeabilidade vascular, pela medida indireta de albumina no sobrenadante do LBA;

$\checkmark \quad$ diminuiu a expressão de moléculas de adesão, especialmente a ICAM-1 em neutrófilos do LBA.

\subsection{Conclusão geral}

Mostramos pela primeira vez que os tratamentos profilático e terapêutico com CBD (20 ou $80 \mathrm{mg} / \mathrm{kg}$ ) produz efeito anti-inflamatório prolongado em um modelo murino de $A L I$, muito provavelmente em decorrência de um aumento da sinalização dos receptores de adenosina A2A. Por esta razão, acreditamos que o CBD venha a ser, no futuro, uma ferramenta terapêutica útil no tratamento de doenças inflamatórias pulmonares, tais como a ALI e a ARDS. 


\section{REFERÊNCIAS}

ADAMS, R.; HUNT, M.; CLARK, J. H. Structure of cannabidiol, a product isolated from the marihuana extract of Minnesota wild hemp. J Am Chem Soc., v. 62, n., p. 196-200, 1940.

AGARWAL, S. K.; MARSHALL, G. D., JR. Dexamethasone promotes type 2 cytokine production primarily through inhibition of type 1 cytokines. J Interferon Cytokine Res., v. 21, n. 3, p. 147-155, 2001.

AHRENS, J.; DEMIR, R.; LEUWER, M.; DE LA ROCHE, J.; KRAMPFL, K.; FOADI, N.; KARST, M.; HAESELER, G. The nonpsychotropic cannabinoid cannabidiol modulates and directly activates alpha-1 and alpha-1-Beta glycine receptor function.

Pharmacology., v. 83, n. 4, p. 217-222, 2009.

ALHAMORUNI, A.; WRIGHT, K. L.; LARVIN, M.; O'SULLIVAN, S. E. Cannabinoids mediate opposing effects on inflammation-induced intestinal permeability. $\mathbf{B r} \mathbf{J}$ Pharmacol., v., n., p., 2011.

ALVES, G. J.; PALERMO-NETO, J. [Neuroimmunomodulation: the cross-talk between nervous and immune systems]. Rev Bras Psiquiatr., v. 29, n. 4, p. 363369, 2007.

ATWOOD, B. K.; MACKIE, K. CB2: a cannabinoid receptor with an identity crisis. $\mathbf{B r}$ J Pharmacol., v. 160, n. 3, p. 467-479, 2010.

BAKER, D.; JACKSON, S. J.; PRYCE, G. Cannabinoid control of neuroinflammation related to multiple sclerosis. Br J Pharmacol., v. 152, n. 5, p. 649-654, 2007.

BALAMAYOORAN, G.; BATRA, S.; BALAMAYOORAN, T.; CAI, S.; JEYASEELAN, S. MCP-1 Regulates Pulmonary Host Defense via Neutrophil Recruitment During E. coli Infection. Infect Immun., v. 79, n. 11, p. 4588-4599, 2011.

BASSO, A. S.; PINTO, F. A.; RUSSO, M.; BRITTO, L. R.; DE SA-ROCHA, L. C.; PALERMO NETO, J. Neural correlates of IgE-mediated food allergy. $\mathbf{J}$ Neuroimmunol., v. 140, n. 1-2, p. 69-77, 2003.

BASSO, A. S.; COSTA-PINTO, F. A.; BRITTO, L. R.; DE SA-ROCHA, L. C.; PALERMO-NETO, J. Neural pathways involved in food allergy signaling in the mouse brain: role of capsaicin-sensitive afferents. Brain Res., v. 1009, n. 1-2, p. 181-188, 2004.

BESEDOVSKY, H.; SORKIN, E.; FELIX, D.; HAAS, H. Hypothalamic changes during the immune response. Eur J Immunol., v. 7, n. 5, p. 323-325, 1977.

BESEDOVSKY, H.; SORKIN, E. Network of immune-neuroendocrine interactions.

Clin Exp Immunol., v. 27, n. 1, p. 1-12, 1977. 
BESEDOVSKY, H.; DEL REY, A.; SORKIN, E.; DINARELLO, C. A. Immunoregulatory feedback between interleukin-1 and glucocorticoid hormones. Science., v. 233, n. 4764, p. 652-654, 1986.

BESEDOVSKY, H. O.; DEL REY, A. Immune-neuro-endocrine interactions: facts and hypotheses. Endocr Rev., v. 17, n. 1, p. 64-102, 1996.

BESEDOVSKY, H. O.; REY, A. D. Physiology of psychoneuroimmunology: a personal view. Brain Behav Immun., v. 21, n. 1, p. 34-44, 2007.

BISOGNO, T.; HANUS, L.; DE PETROCELLIS, L.; TCHILIBON, S.; PONDE, D. E.; BRANDI, I.; MORIELLO, A. S.; DAVIS, J. B.; MECHOULAM, R.; DI MARZO, V. Molecular targets for cannabidiol and its synthetic analogues: effect on vanilloid VR1 receptors and on the cellular uptake and enzymatic hydrolysis of anandamide. $\mathbf{B r} \mathbf{J}$ Pharmacol., v. 134, n. 4, p. 845-852, 2001.

BITENCOURT, R. M.; PAMPLONA, F. A.; TAKAHASHI, R. N. Facilitation of contextual fear memory extinction and anti-anxiogenic effects of AM404 and cannabidiol in conditioned rats. Eur Neuropsychopharmacol., v. 18, n. 12, p. 849859, 2008.

BLALOCK, J. E.; SMITH, E. M. Human leukocyte interferon: structural and biological relatedness to adrenocorticotropic hormone and endorphins. Proc Natl Acad Sci U S A., v. 77, n. 10, p. 5972-5974, 1980.

BLALOCK, J. E. The immune system as a sensory organ. J Immunol., v. 132, n. 3, p. 1067-1070, 1984.

BLALOCK, J. E. The immune system as the sixth sense. J Intern Med., v. 257, n. 2, p. 126-138, 2005.

BLUTHE, R. M.; LAYE, S.; MICHAUD, B.; COMBE, C.; DANTZER, R.; PARNET, P. Role of interleukin-1beta and tumour necrosis factor-alpha in lipopolysaccharideinduced sickness behaviour: a study with interleukin-1 type I receptor-deficient mice. Eur J Neurosci., v. 12, n. 12, p. 4447-4456, 2000a.

BLUTHE, R. M.; MICHAUD, B.; POLI, V.; DANTZER, R. Role of IL-6 in cytokineinduced sickness behavior: a study with IL-6 deficient mice. Physiol Behav., v. 70, n. 3-4, p. 367-373, 2000b.

BORRELLI, F.; AVIELLO, G.; ROMANO, B.; ORLANDO, P.; CAPASSO, R.; MAIELLO, F.; GUADAGNO, F.; PETROSINO, S.; CAPASSO, F.; DI MARZO, V.; IZZO, A. A. Cannabidiol, a safe and non-psychotropic ingredient of the marijuana plant Cannabis sativa, is protective in a murine model of colitis. $\mathbf{J}$ Mol Med (Berl)., $\mathbf{v}$. 87, n. 11, p. 1111-1121, 2009.

BRADLEY, L. M.; MISHELL, R. I. Differential effects of glucocorticosteroids on the functions of helper and suppressor T lymphocytes. Proc Natl Acad Sci U S A., v. 78, n. 5, p. 3155-3159, 1981. 
BREIVOGEL, C. S.; CHILDERS, S. R. The functional neuroanatomy of brain cannabinoid receptors. Neurobiol Dis., v. 5, n. 6, pt B, p. 417-431, 1998.

CAMPOS, A. C.; GUIMARAES, F. S. Involvement of 5HT1A receptors in the anxiolytic-like effects of cannabidiol injected into the dorsolateral periaqueductal gray of rats. Psychopharmacology (Berl)., v. 199, n. 2, p. 223-230, 2008.

CAPASSO, R.; BORRELLI, F.; AVIELLO, G.; ROMANO, B.; SCALISI, C.; CAPASSO, F.; IZZO, A. A. Cannabidiol, extracted from Cannabis sativa, selectively inhibits inflammatory hypermotility in mice. Br J Pharmacol., v. 154, n. 5, p. 10011008, 2008.

CARLINI, E. A.; LEITE, J. R.; TANNHAUSER, M.; BERARDI, A. C. Letter: Cannabidiol and Cannabis sativa extract protect mice and rats against convulsive agents. J Pharm Pharmacol., v. 25, n. 8, p. 664-665, 1973.

CARRIER, E. J.; AUCHAMPACH, J. A.; HILLARD, C. J. Inhibition of an equilibrative nucleoside transporter by cannabidiol: a mechanism of cannabinoid immunosuppression. Proc Natl Acad Sci U S A., v. 103, n. 20, p. 7895-7900, 2006.

CASTILLO, A.; TOLON, M. R.; FERNANDEZ-RUIZ, J.; ROMERO, J.; MARTINEZORGADO, J. The neuroprotective effect of cannabidiol in an in vitro model of newborn hypoxic-ischemic brain damage in mice is mediated by $\mathrm{CB}(2)$ and adenosine receptors. Neurobiol Dis., v. 37, n. 2, p. 434-440, 2010.

CHEN, Y.; CORRIDEN, R.; INOUE, Y.; YIP, L.; HASHIGUCHI, N.; ZINKERNAGEL, A.; NIZET, V.; INSEL, P. A.; JUNGER, W. G. ATP release guides neutrophil chemotaxis via P2Y2 and A3 receptors. Science., v. 314, n. 5806, p. 1792-1795, 2006.

CORTELING, R.; WYSS, D.; TRIFILIEFF, A. In vivo models of lung neutrophil activation. Comparison of mice and hamsters. BMC Pharmacol., v. 2, n., p. 1, 2002.

COSTA-PINTO, F. A.; BASSO, A. S.; BRITTO, L. R.; MALUCELLI, B. E.; RUSSO, M. Avoidance behavior and neural correlates of allergen exposure in a murine model of asthma. Brain Behav Immun., v. 19, n. 1, p. 52-60, 2005.

COSTA-PINTO, F. A.; BASSO, A. S.; DE SA-ROCHA, L. C.; BRITTO, L. R.; RUSSO, M.; PALERMO-NETO, J. Neural correlates of IgE-mediated allergy. Ann N Y Acad Sci., v. 1088, n., p. 116-131, 2006.

COSTA-PINTO, F. A.; COHN, D. W.; SA-ROCHA, V. M.; SA-ROCHA, L. C.; PALERMO-NETO, J. Behavior: a relevant tool for brain-immune system interaction studies. Ann N Y Acad Sci., v. 1153, n., p. 107-119, 2009.

COSTA-PINTO, F. A.; PALERMO-NETO, J. Neuroimmune interactions in stress. Neuroimmunomodulation., v. 17, n. 3, p. 196-199, 2010.

COSTA, B.; GIAGNONI, G.; FRANKE, C.; TROVATO, A. E.; COLLEONI, M. Vanilloid TRPV1 receptor mediates the antihyperalgesic effect of the nonpsychoactive 
cannabinoid, cannabidiol, in a rat model of acute inflammation. Br J Pharmacol., v. 143, n. 2, p. 247-250, 2004.

CROXFORD, J. L.; YAMAMURA, T. Cannabinoids and the immune system: potential for the treatment of inflammatory diseases? J Neuroimmunol., v. 166, n. 1-2, p. 318, 2005.

D'ALESSIO, F. R.; TSUSHIMA, K.; AGGARWAL, N. R.; WEST, E. E.; WILLETT, M. H.; BRITOS, M. F.; PIPELING, M. R.; BROWER, R. G.; TUDER, R. M.; MCDYER, J. F.; KING, L. S. CD4+CD25+Foxp3+ Tregs resolve experimental lung injury in mice and are present in humans with acute lung injury. J Clin Invest., v. 119, n. 10, p. 2898-2913, 2009.

DANTZER, R.; O'CONNOR, J. C.; FREUND, G. G.; JOHNSON, R. W.; KELLEY, K. $W$. From inflammation to sickness and depression: when the immune system subjugates the brain. Nat Rev Neurosci., v. 9, n. 1, p. 46-56, 2008.

DE FILIPPIS, D.; ESPOSITO, G.; CIRILLO, C.; CIPRIANO, M.; DE WINTER, B. Y.; SCUDERI, C.; SARNELLI, G.; CUOMO, R.; STEARDO, L.; DE MAN, J. G.; IUVONE, $T$. Cannabidiol Reduces Intestinal Inflammation through the Control of Neuroimmune Axis. PLoS One., v. 6, n. 12, p. e28159, 2011.

DE PETROCELLIS, L.; ORLANDO, P.; MORIELLO, A. S.; AVIELLO, G.; STOTT, C.; IZZO, A. A.; DI MARZO, V. Cannabinoid actions at TRPV channels: effects on TRPV3 and TRPV4 and their potential relevance to gastrointestinal inflammation. Acta Physiol (Oxf)., v., n., p., 2011.

DEVANE, W. A.; DYSARZ, F. A., 3RD; JOHNSON, M. R.; MELVIN, L. S.; HOWLETT, A. C. Determination and characterization of a cannabinoid receptor in rat brain. Mol Pharmacol., v. 34, n. 5, p. 605-613, 1988.

DEVANE, W. A.; HANUS, L.; BREUER, A.; PERTWEE, R. G.; STEVENSON, L. A.; GRIFFIN, G.; GIBSON, D.; MANDELBAUM, A.; ETINGER, A.; MECHOULAM, R. Isolation and structure of a brain constituent that binds to the cannabinoid receptor. Science., v. 258, n. 5090, p. 1946-1949, 1992.

DIPATRIZIO, N. V.; ASTARITA, G.; SCHWARTZ, G.; LI, X.; PIOMELLI, D. Endocannabinoid signal in the gut controls dietary fat intake. Proc Natl Acad Sci U S A., v. 108, n. 31, p. 12904-12908, 2011.

DURST, R.; DANENBERG, H.; GALLILY, R.; MECHOULAM, R.; MEIR, K.; GRAD, E.; BEERI, R.; PUGATSCH, T.; TARSISH, E.; LOTAN, C. Cannabidiol, a nonpsychoactive Cannabis constituent, protects against myocardial ischemic reperfusion injury. Am J Physiol Heart Circ Physiol., v. 293, n. 6, p. H3602-3607, 2007.

ECKLE, T.; FULLBIER, L.; WEHRMANN, M.; KHOURY, J.; MITTELBRONN, M.; IBLA, J.; ROSENBERGER, P.; ELTZSCHIG, H. K. Identification of ectonucleotidases CD39 and CD73 in innate protection during acute lung injury. J Immunol., v. 178, n. 12, p. 8127-8137, 2007. 
ECKLE, T.; GRENZ, A.; LAUCHER, S.; ELTZSCHIG, H. K. A2B adenosine receptor signaling attenuates acute lung injury by enhancing alveolar fluid clearance in mice. $\mathbf{J}$ Clin Invest., v. 118, n. 10, p. 3301-3315, 2008.

ECKLE, T.; KOEPPEN, M.; ELTZSCHIG, H. K. Role of extracellular adenosine in acute lung injury. Physiology (Bethesda)., v. 24, n., p. 298-306, 2009.

EL-REMESSY, A. B.; KHALIL, I. E.; MATRAGOON, S.; ABOU-MOHAMED, G.; TSAI, N. J.; ROON, P.; CALDWELL, R. B.; CALDWELL, R. W.; GREEN, K.; LIOU, G. I. Neuroprotective effect of (-)Delta9-tetrahydrocannabinol and cannabidiol in N-methylD-aspartate-induced retinal neurotoxicity: involvement of peroxynitrite. Am J Pathol., v. 163 , n. 5, p. 1997-2008, 2003.

EL-REMESSY, A. B.; AL-SHABRAWEY, M.; KHALIFA, Y.; TSAI, N. T.; CALDWELL, R. B.; LIOU, G. I. Neuroprotective and blood-retinal barrier-preserving effects of cannabidiol in experimental diabetes. Am J Pathol., v. 168, n. 1, p. 235-244, 2006.

EL-REMESSY, A. B.; TANG, Y.; ZHU, G.; MATRAGOON, S.; KHALIFA, Y.; LIU, E. K.; LIU, J. Y.; HANSON, E.; MIAN, S.; FATTEH, N.; LIOU, G. I. Neuroprotective effects of cannabidiol in endotoxin-induced uveitis: critical role of p38 MAPK activation. Mol Vis., v. 14, n., p. 2190-2203, 2008.

ELENKOV, I. J.; PAPANICOLAOU, D. A.; WILDER, R. L.; CHROUSOS, G. P. Modulatory effects of glucocorticoids and catecholamines on human interleukin-12 and interleukin-10 production: clinical implications. Proc Assoc Am Physicians., v. 108, n. 5, p. 374-381, 1996.

ELENKOV, I. J.; CHROUSOS, G. P. Stress Hormones, Th1/Th2 patterns, Pro/Antiinflammatory Cytokines and Susceptibility to Disease. Trends Endocrinol Metab., v. 10, n. 9, p. 359-368, 1999.

FELTEN, D. L.; FELTEN, S. Y.; CARLSON, S. L.; OLSCHOWKA, J. A.; LIVNAT, S. Noradrenergic and peptidergic innervation of lymphoid tissue. J Immunol., v. 135, n. 2 Suppl, p. 755s-765s, 1985.

FIALKOW, L.; VIEIRA, S. R.; FERNANDES, A. K.; SILVA, D. R.; BOZZETTI, M. C. Acute lung injury and acute respiratory distress syndrome at the intensive care unit of a general university hospital in Brazil. An epidemiological study using the AmericanEuropean Consensus Criteria. Intensive Care Med., v. 28, n. 11, p. 1644-1648, 2002.

FRANCHIMONT, D.; GALON, J.; GADINA, M.; VISCONTI, R.; ZHOU, Y.; ARINGER, M.; FRUCHT, D. M.; CHROUSOS, G. P.; O'SHEA, J. J. Inhibition of Th1 immune response by glucocorticoids: dexamethasone selectively inhibits IL-12-induced Stat4 phosphorylation in T lymphocytes. J Immunol., v. 164, n. 4, p. 1768-1774, 2000.

FREUND, T. F.; KATONA, I.; PIOMELLI, D. Role of endogenous cannabinoids in synaptic signaling. Physiol Rev., v. 83, n. 3, p. 1017-1066, 2003. 
GALIEGUE, S.; MARY, S.; MARCHAND, J.; DUSSOSSOY, D.; CARRIERE, D.; CARAYON, P.; BOUABOULA, M.; SHIRE, D.; LE FUR, G.; CASELLAS, P.

Expression of central and peripheral cannabinoid receptors in human immune tissues and leukocyte subpopulations. Eur J Biochem., v. 232, n. 1, p. 54-61, 1995.

GLASS, M.; DRAGUNOW, M.; FAULL, R. L. Cannabinoid receptors in the human brain: a detailed anatomical and quantitative autoradiographic study in the fetal, neonatal and adult human brain. Neuroscience., v. 77, n. 2, p. 299-318, 1997.

GOEHLER, L. E.; LYTE, M.; GAYKEMA, R. P. Infection-induced viscerosensory signals from the gut enhance anxiety: implications for psychoneuroimmunology. Brain Behav Immun., v. 21, n. 6, p. 721-726, 2007.

GOLDBLUM, S. E.; WU, K. M.; JAY, M. Lung myeloperoxidase as a measure of pulmonary leukostasis in rabbits. J Appl Physiol., v. 59, n. 6, p. 1978-1985, 1985.

GOMES, F. V.; RESSTEL, L. B.; GUIMARAES, F. S. The anxiolytic-like effects of cannabidiol injected into the bed nucleus of the stria terminalis are mediated by 5 HT1A receptors. Psychopharmacology (Berl)., v. 213, n. 2-3, p. 465-473, 2011.

GROMMES, J.; SOEHNLEIN, O. Contribution of neutrophils to acute lung injury. Mol Med., v. 17, n. 3-4, p. 293-307, 2011.

GUIMARAES, F. S.; CHIARETTI, T. M.; GRAEFF, F. G.; ZUARDI, A. W. Antianxiety effect of cannabidiol in the elevated plus-maze. Psychopharmacology (Berl)., v. 100, n. 4, p. 558-559, 1990.

HASHIMOTODANI, Y.; OHNO-SHOSAKU, T.; KANO, M. Endocannabinoids and synaptic function in the CNS. Neuroscientist., v. 13, n. 2, p. 127-137, 2007.

HEGDE, V. L.; NAGARKATTI, P. S.; NAGARKATTI, M. Role of myeloid-derived suppressor cells in amelioration of experimental autoimmune hepatitis following activation of TRPV1 receptors by cannabidiol. PLoS One., v. 6, n. 4, p. e18281, 2011.

HERKENHAM, M.; LYNN, A. B.; JOHNSON, M. R.; MELVIN, L. S.; DE COSTA, B. R.; RICE, K. C. Characterization and localization of cannabinoid receptors in rat brain: a quantitative in vitro autoradiographic study. J Neurosci., v. 11, n. 2, p. 563583, 1991.

IGNATOWSKI, T. A.; GALLANT, S.; SPENGLER, R. N. Temporal regulation by adrenergic receptor stimulation of macrophage (M phi)-derived tumor necrosis factor (TNF) production post-LPS challenge. J Neuroimmunol., v. 65, n. 2, p. 107-117, 1996.

IMPELLIZZERI, D.; DI PAOLA, R.; ESPOSITO, E.; MAZZON, E.; PATERNITI, I.; MELANI, A.; BRAMANTI, P.; PEDATA, F.; CUZZOCREA, S. CGS 21680, an agonist of the adenosine $(A(2 A))$ receptor, decreases acute lung inflammation. Eur $\mathbf{J}$ Pharmacol., v.668, n. 1-2, p. 305-316, 2011. 
IZZO, A. A.; BORRELLI, F.; CAPASSO, R.; DI MARZO, V.; MECHOULAM, R. Nonpsychotropic plant cannabinoids: new therapeutic opportunities from an ancient herb. Trends Pharmacol Sci., v. 30, n. 10, p. 515-527, 2009.

JAMONTT, J. M.; MOLLEMAN, A.; PERTWEE, R. G.; PARSONS, M. E. The effects of Delta-tetrahydrocannabinol and cannabidiol alone and in combination on damage, inflammation and in vitro motility disturbances in rat colitis. Br J Pharmacol., v. 160, n. 3, p. 712-723, 2010.

KARNIOL, I. G.; CARLINI, E. A. Pharmacological interaction between cannabidiol and delta 9-tetrahydrocannabinol. Psychopharmacologia., v. 33, n. 1, p. 53-70, 1973.

KLEBANOFF, S. J. Myeloperoxidase: friend and foe. J Leukoc Biol., v. 77, n. 5, p. 598-625, 2005.

KLEIN, T. W.; NEWTON, C.; FRIEDMAN, H. Cannabinoid receptors and immunity. Immunol Today., v. 19, n. 8, p. 373-381, 1998.

KLEIN, T. W.; NEWTON, C.; LARSEN, K.; LU, L.; PERKINS, I.; NONG, L.; FRIEDMAN, $\mathrm{H}$. The cannabinoid system and immune modulation. J Leukoc Biol., v. 74, n. 4, p. 486-496, 2003.

KOBAYASHI, Y. The role of chemokines in neutrophil biology. Front Biosci., v. 13, n., p. 2400-2407, 2008.

KOZELA, E.; PIETR, M.; JUKNAT, A.; RIMMERMAN, N.; LEVY, R.; VOGEL, Z. Cannabinoids Delta(9)-tetrahydrocannabinol and cannabidiol differentially inhibit the lipopolysaccharide-activated NF-kappaB and interferon-beta/STAT proinflammatory pathways in BV-2 microglial cells. J Biol Chem., v. 285, n. 3, p. 1616-1626, 2010.

KOZELA, E.; LEV, N.; KAUSHANSKY, N.; EILAM, R.; RIMMERMAN, N.; LEVY, R.; BEN-NUN, A.; JUKNAT, A.; VOGEL, Z. Cannabidiol inhibits pathogenic T cells, decreases spinal microglial activation and ameliorates multiple sclerosis-like disease in C57BL/6 mice. Br J Pharmacol., v. 163, n. 7, p. 1507-1519, 2011.

LIBERMAN, A. C.; REFOJO, D.; DRUKER, J.; TOSCANO, M.; REIN, T.; HOLSBOER, F.; ARZT, E. The activated glucocorticoid receptor inhibits the transcription factor T-bet by direct protein-protein interaction. Faseb J., v. 21, n. 4, p. 1177-1188, 2007a.

LIBERMAN, A. C.; DRUKER, J.; PERONE, M. J.; ARZT, E. Glucocorticoids in the regulation of transcription factors that control cytokine synthesis. Cytokine \& growth factor reviews., v. 18, n. 1-2, p. 45-56, 2007b.

LIBERMAN, A. C.; DRUKER, J.; REFOJO, D.; HOLSBOER, F.; ARZT, E. Glucocorticoids inhibit GATA-3 phosphorylation and activity in T cells. Faseb J., v. 23, n. 5, p. 1558-1571, 2009. 
LIOU, G.; EL-REMESSY, A.; IBRAHIM, A.; CALDWELL, R.; KHALIFA, Y.; GUNES, A.; NUSSBAUM, J. Cannabidiol As a Putative Novel Therapy for Diabetic

Retinopathy: A Postulated Mechanism of Action as an Entry Point for BiomarkerGuided Clinical Development. Curr Pharmacogenomics Person Med., v. 7, n. 3, p. 215-222, 2009.

LIOU, G. I.; AUCHAMPACH, J. A.; HILLARD, C. J.; ZHU, G.; YOUSUFZAI, B.; MIAN, S.; KHAN, S.; KHALIFA, Y. Mediation of cannabidiol anti-inflammation in the retina by equilibrative nucleoside transporter and A2A adenosine receptor. Invest Ophthalmol Vis Sci., v. 49, n. 12, p. 5526-5531, 2008.

LIU, W.; TANG, Y.; FENG, J. Cross talk between activation of microglia and astrocytes in pathological conditions in the central nervous system. Life Sci., v. 89, n. 5-6, p. 141-146, 2011.

LUKASHEV, D. E.; SMITH, P. T.; CALDWELL, C. C.; OHTA, A.; APASOV, S. G.; SITKOVSKY, M. V. Analysis of A2a receptor-deficient mice reveals no significant compensatory increases in the expression of $\mathrm{A} 2 \mathrm{~b}, \mathrm{~A} 1$, and $\mathrm{A} 3$ adenosine receptors in lymphoid organs. Biochem Pharmacol., v. 65, n. 12, p. 2081-2090, 2003.

MADDEN, K. S.; FELTEN, D. L. Experimental basis for neural-immune interactions. Physiol Rev., v. 75, n. 1, p. 77-106, 1995.

MAILLEUX, P.; VANDERHAEGHEN, J. J. Localization of cannabinoid receptor in the human developing and adult basal ganglia. Higher levels in the striatonigral neurons. Neurosci Lett., v. 148, n. 1-2, p. 173-176, 1992.

MALFAIT, A. M.; GALLILY, R.; SUMARIWALLA, P. F.; MALIK, A. S.; ANDREAKOS, E.; MECHOULAM, R.; FELDMANN, M. The nonpsychoactive cannabis constituent cannabidiol is an oral anti-arthritic therapeutic in murine collagen-induced arthritis.

Proc Natl Acad Sci U S A., v. 97, n. 17, p. 9561-9566, 2000.

MASSI, P.; VALENTI, M.; VACCANI, A.; GASPERI, V.; PERLETTI, G.; MARRAS, E.; FEZZA, F.; MACCARRONE, M.; PAROLARO, D. 5-Lipoxygenase and anandamide hydrolase (FAAH) mediate the antitumor activity of cannabidiol, a non-psychoactive cannabinoid. J Neurochem., v. 104, n. 4, p. 1091-1100, 2008.

MATSUDA, L. A.; LOLAIT, S. J.; BROWNSTEIN, M. J.; YOUNG, A. C.; BONNER, T. I. Structure of a cannabinoid receptor and functional expression of the cloned cDNA. Nature., v. 346, n. 6284, p. 561-564, 1990.

MECHOULAM, R.; SHVO, Y. Hashish, Structure of Cannabidiol. Tetrahedron., v. 19, n. 12, p. 2073-2078, 1963.

MECHOULAM, R.; BEN-SHABAT, S.; HANUS, L.; LIGUMSKY, M.; KAMINSKI, N. E.; SCHATZ, A. R.; GOPHER, A.; ALMOG, S.; MARTIN, B. R.; COMPTON, D. R.; ET $\mathrm{AL}$. Identification of an endogenous 2-monoglyceride, present in canine gut, that binds to cannabinoid receptors. Biochem Pharmacol., v. 50, n. 1, p. 83-90, 1995. 
MECHOULAM, R.; PARKER, L. A.; GALLILY, R. Cannabidiol: an overview of some pharmacological aspects. J Clin Pharmacol., v. 42, n. 11 Suppl, p. 11S-19S, 2002.

MELTZER, J. C.; MACNEIL, B. J.; SANDERS, V.; PYLYPAS, S.; JANSEN, A. H.; GREENBERG, A. H.; NANCE, D. M. Stress-induced suppression of in vivo splenic cytokine production in the rat by neural and hormonal mechanisms. Brain Behav Immun., v. 18, n. 3, p. 262-273, 2004.

MUKHOPADHYAY, P.; RAJESH, M.; HORVATH, B.; BATKAI, S.; PARK, O.; TANCHIAN, G.; GAO, R. Y.; PATEL, V.; WINK, D. A.; LIAUDET, L.; HASKO, G.; MECHOULAM, R.; PACHER, P. Cannabidiol protects against hepatic ischemia/reperfusion injury by attenuating inflammatory signaling and response, oxidative/nitrative stress, and cell death. Free Radic Biol Med., v. 50, n. 10, p. 1368$1381,2011$.

MUNRO, S.; THOMAS, K. L.; ABU-SHAAR, M. Molecular characterization of a peripheral receptor for cannabinoids. Nature., v. 365, n. 6441, p. 61-65, 1993.

NANCE, D. M.; SANDERS, V. M. Autonomic innervation and regulation of the immune system (1987-2007). Brain Behav Immun., v. 21, n. 6, p. 736-745, 2007.

NGAMSRI, K. C.; WAGNER, R.; VOLLMER, I.; STARK, S.; REUTERSHAN, J. Adenosine receptor $\mathrm{A} 1$ regulates polymorphonuclear cell trafficking and microvascular permeability in lipopolysaccharide-induced lung injury. J Immunol., v. 185, n. 7, p. 4374-4384, 2010.

O'SULLIVAN, S. E.; SUN, Y.; BENNETT, A. J.; RANDALL, M. D.; KENDALL, D. A. Time-dependent vascular actions of cannabidiol in the rat aorta. Eur J Pharmacol., v. 612 , n. 1-3, p. 61-68, 2009.

OHLSSON, A.; LINDGREN, J. E.; ANDERSSON, S.; AGURELL, S.; GILLESPIE, H.; HOLLISTER, L. E. Single-dose kinetics of deuterium-labelled cannabidiol in man after smoking and intravenous administration. Biomed Environ Mass Spectrom., v. 13, n. 2, p. 77-83, 1986.

OLIVEIRA, R. H.; BASILLE FILHO, A. Incidence of acute lung injury and acute respiratory distress syndrome in the intensive care unit of a university hospital: a prospective study. J Bras Pneumol., v. 32, n. 1, p. 35-42, 2006.

PALERMO-NETO, J.; DE OLIVEIRA MASSOCO, C.; ROBESPIERRE DE SOUZA, W. Effects of physical and psychological stressors on behavior, macrophage activity, and Ehrlich tumor growth. Brain Behav Immun., v. 17, n. 1, p. 43-54, 2003.

PALERMO NETO, J.; MASSOCO, C. O.; FAVARE, R. C. Effects of maternal stress on anxiety levels, macrophage activity, and Ehrlich tumor growth. Neurotoxicol Teratol., v. 23, n. 5, p. 497-507, 2001.

PERTWEE, R. G. Pharmacology of cannabinoid CB1 and CB2 receptors. Pharmacol Ther., v. 74, n. 2, p. 129-180, 1997. 
QUAN, N.; BANKS, W. A. Brain-immune communication pathways. Brain Behav Immun., v. 21, n. 6, p. 727-735, 2007.

RAJESH, M.; MUKHOPADHYAY, P.; BATKAI, S.; PATEL, V.; SAITO, K.; MATSUMOTO, S.; KASHIWAYA, Y.; HORVATH, B.; MUKHOPADHYAY, B.; BECKER, L.; HASKO, G.; LIAUDET, L.; WINK, D. A.; VEVES, A.; MECHOULAM, R.; PACHER, P. Cannabidiol attenuates cardiac dysfunction, oxidative stress, fibrosis, and inflammatory and cell death signaling pathways in diabetic cardiomyopathy. $\mathbf{J}$ Am Coll Cardiol., v. 56, n. 25, p. 2115-2125, 2010.

REICHLIN, S. Neuroendocrine-immune interactions. N Engl J Med., v. 329, n. 17, p. 1246-1253, 1993.

REUTERSHAN, J.; MORRIS, M. A.; BURCIN, T. L.; SMITH, D. F.; CHANG, D.; SAPRITO, M. S.; LEY, K. Critical role of endothelial CXCR2 in LPS-induced neutrophil migration into the lung. J Clin Invest., v. 116, n. 3, p. 695-702, 2006.

REUTERSHAN, J.; CAGNINA, R. E.; CHANG, D.; LINDEN, J.; LEY, K. Therapeutic anti-inflammatory effects of myeloid cell adenosine receptor A2a stimulation in lipopolysaccharide-induced lung injury. J Immunol., v. 179, n. 2, p. 1254-1263, 2007.

REUTERSHAN, J.; VOLLMER, I.; STARK, S.; WAGNER, R.; NGAMSRI, K. C.; ELTZSCHIG, H. K. Adenosine and inflammation: CD39 and CD73 are critical mediators in LPS-induced PMN trafficking into the lungs. FASEB J., v. 23, n. 2, p. 473-482, 2009.

RIBEIRO, A.; FERRAZ-DE-PAULA, V.; PINHEIRO, M. L.; PALERMO-NETO, J. Dose-response effects of systemic anandamide administration in mice sequentially submitted to the open field and elevated plus-maze tests. Braz J Med Biol Res., v. 42, n. 6, p. 556-560, 2009.

RODRIGUEZ DE FONSECA, F.; DEL ARCO, I.; BERMUDEZ-SILVA, F. J.; BILBAO, A.; CIPPITELLI, A.; NAVARRO, M. The endocannabinoid system: physiology and pharmacology. Alcohol Alcohol., v. 40, n. 1, p. 2-14, 2005.

RUBENFELD, G. D.; CALDWELL, E.; PEABODY, E.; WEAVER, J.; MARTIN, D. P.; NEFF, M.; STERN, E. J.; HUDSON, L. D. Incidence and outcomes of acute lung injury. N Engl J Med., v. 353, n. 16, p. 1685-1693, 2005.

SA-ROCHA, V. M.; SA-ROCHA, L. C.; PALERMO-NETO, J. Variations in behavior, innate immunity and host resistance to B16F10 melanoma growth in mice that present social stable hierarchical ranks. Physiol Behav., v. 88, n. 1-2, p. 108-115, 2006.

SAMARA, E.; BIALER, M.; MECHOULAM, R. Pharmacokinetics of cannabidiol in dogs. Drug Metab Dispos., v. 16, n. 3, p. 469-472, 1988.

SCHATZ, A. R.; LEE, M.; CONDIE, R. B.; PULASKI, J. T.; KAMINSKI, N. E. Cannabinoid receptors $\mathrm{CB} 1$ and $\mathrm{CB} 2$ : a characterization of expression and adenylate 
cyclase modulation within the immune system. Toxicol Appl Pharmacol., v. 142, n. 2, p. 278-287, 1997.

SCHINGNITZ, U.; HARTMANN, K.; MACMANUS, C. F.; ECKLE, T.; ZUG, S.; COLGAN, S. P.; ELTZSCHIG, H. K. Signaling through the A2B adenosine receptor dampens endotoxin-induced acute lung injury. J Immunol., v. 184, n. 9, p. 52715279, 2010.

SELYE, H. A syndrome produced by diverse nocuous agents. 1936. J Neuropsychiatry Clin Neurosci., v. 10, n. 2, p. 230-231, 1998.

SHIMIZU, M.; HASEGAWA, N.; NISHIMURA, T.; ENDO, Y.; SHIRAISHI, Y.; YAMASAWA, W.; KOH, H.; TASAKA, S.; SHIMADA, H.; NAKANO, Y.; FUJISHIMA, S.; YAMAGUCHI, K.; ISHIZAKA, A. Effects of TNF-alpha-converting enzyme inhibition on acute lung injury induced by endotoxin in the rat. Shock., v. 32, n. 5, p. 535-540, 2009.

SMITH, E. M.; BLALOCK, J. E. A molecular basis for interactions between the immune and neuroendocrine systems. Int J Neurosci., v. 38, n. 3-4, p. 455-464, 1988.

STELLA, N. Endocannabinoid signaling in microglial cells. Neuropharmacology., v. 56, n., p. 244-253, 2009. Supplement ,1.

SZARKA, R. J.; WANG, N.; GORDON, L.; NATION, P. N.; SMITH, R. H. A murine model of pulmonary damage induced by lipopolysaccharide via intranasal instillation. J Immunol Methods., v. 202, n. 1, p. 49-57, 1997.

TAKEDA, S.; USAMI, N.; YAMAMOTO, I.; WATANABE, K. Cannabidiol-2',6'-dimethyl ether, a cannabidiol derivative, is a highly potent and selective 15-lipoxygenase inhibitor. Drug Metab Dispos., v. 37, n. 8, p. 1733-1737, 2009.

THOMAS, A.; BAILLIE, G. L.; PHILLIPS, A. M.; RAZDAN, R. K.; ROSS, R. A.; PERTWEE, R. G. Cannabidiol displays unexpectedly high potency as an antagonist of CB1 and CB2 receptor agonists in vitro. Br J Pharmacol., v. 150, n. 5, p. 613-623, 2007.

TRACEY, K. J. The inflammatory reflex. Nature., v. 420, n. 6917, p. 853-859, 2002.

TRACEY, K. J. Physiology and immunology of the cholinergic antiinflammatory pathway. J Clin Invest., v. 117, n. 2, p. 289-296, 2007.

TSUSHIMA, K.; KING, L. S.; AGGARWAL, N. R.; DE GORORDO, A.; D'ALESSIO, F. R.; KUBO, K. Acute lung injury review. Intern Med., v. 48, n. 9, p. 621-630, 2009.

VIVEROS, M. P.; MARCO, E. M.; FILE, S. E. Endocannabinoid system and stress and anxiety responses. Pharmacol Biochem Behav., v. 81, n. 2, p. 331-342, 2005. 
WAGNER, R.; NGAMSRI, K. C.; STARK, S.; VOLLMER, I.; REUTERSHAN, J. Adenosine receptor A3 is a critical mediator in LPS-induced pulmonary inflammation. Am J Physiol Lung Cell Mol Physiol., v. 299, n. 4, p. L502-512, 2010.

WARE, L. B. Pathophysiology of acute lung injury and the acute respiratory distress syndrome. Semin Respir Crit Care Med., v. 27, n. 4, p. 337-349, 2006.

WATZL, B.; SCUDERI, P.; WATSON, R. R. Influence of marijuana components (THC and $\mathrm{CBD}$ ) on human mononuclear cell cytokine secretion in vitro. Adv Exp Med Biol., v. 288, n., p. 63-70, 1991.

WEBSTER, J. I.; TONELLI, L.; STERNBERG, E. M. Neuroendocrine regulation of immunity. Annu Rev Immunol., v. 20, p. 125-163, 2002.

WEISS, L.; ZEIRA, M.; REICH, S.; HAR-NOY, M.; MECHOULAM, R.; SLAVIN, S.; GALLILY, R. Cannabidiol lowers incidence of diabetes in non-obese diabetic mice. Autoimmunity., v. 39, n. 2, p. 143-151, 2006.

WEISS, L.; ZEIRA, M.; REICH, S.; SLAVIN, S.; RAZ, I.; MECHOULAM, R.; GALLILY, $R$. Cannabidiol arrests onset of autoimmune diabetes in NOD mice.

Neuropharmacology., v. 54, n. 1, p. 244-249, 2008.

WEXLER, B. C.; DOLGIN, A. E.; TRYCZYNSKI, E. W. Effects of a bacterial polysaccharide (piromen) on the pituitary-adrenal axis: further aspects of hypophyseal-mediated control of response. Endocrinology., v. 61, n. 5, p. 488-499, 1957.

WHITE, H. L.; TANSIK, R. L. Effects of delta 9-tetrahydrocannabinol and cannabidiol on phospholipase and other enzymes regulating arachidonate metabolism.

Prostaglandins Med., v. 4, n. 6, p. 409-417, 1980.

XU, N.; RAHMAN, A.; MINSHALL, R. D.; TIRUPPATHI, C.; MALIK, A. B. beta(2)Integrin blockade driven by $\mathrm{E}$-selectin promoter prevents neutrophil sequestration and lung injury in mice. Circ Res., v. 87, n. 3, p. 254-260, 2000.

ZARBOCK, A.; ALLEGRETTI, M.; LEY, K. Therapeutic inhibition of CXCR2 by Reparixin attenuates acute lung injury in mice. Br J Pharmacol., v. 155, n. 3, p. 357364, 2008.

ZARBOCK, A.; DISTASI, M. R.; SMITH, E.; SANDERS, J. M.; KRONKE, G.; HARRY, B. L.; VON VIETINGHOFF, S.; BUSCHER, K.; NADLER, J. L.; LEY, K. Improved survival and reduced vascular permeability by eliminating or blocking 12/15lipoxygenase in mouse models of acute lung injury (ALI). J Immunol., v. 183, n. 7, p. 4715-4722, 2009.

ZUARDI, A. W. Cannabidiol: from an inactive cannabinoid to a drug with wide spectrum of action. Rev Bras Psiquiatr., v. 30, n. 3, p. 271-280, 2008. 